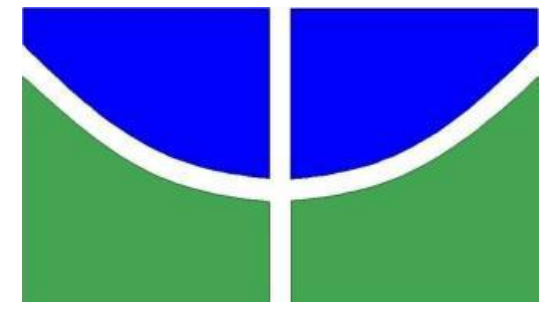

\author{
Universidade de Brasília \\ Instituto de Ciências Biológicas \\ Programa de Pós-Graduação em Ecologia
}

\begin{abstract}
Alelopatia em Lepidaploa aurea (Asteraceae) como Ferramenta de Restauração Ecológica: Potencial para o Controle de Gramíneas Exóticas Invasoras no Cerrado
\end{abstract}

Polliana Gomes Lopes

Brasília, DF

Março de 2016 

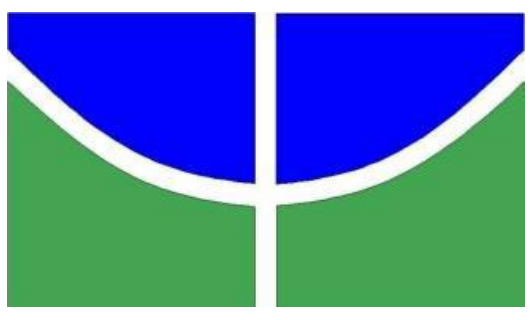

Universidade de Brasília

Instituto de Ciências Biológicas

Programa de Pós-Graduação em Ecologia

\title{
Alelopatia em Lepidaploa aurea (Asteraceae) como Ferramenta de Restauração Ecológica: Potencial para o Controle de Gramíneas Exóticas Invasoras no Cerrado
}

\author{
Polliana Gomes Lopes
}

Orientadora Dra. Isabel Belloni Schmidt

Dissertação submetida ao Departamento de Ecologia do Instituto de Ciências Biológicas da Universidade de Brasília, como requisito parcial do Programa de Pós-Graduação em Ecologia, para obtenção do título de Mestre em Ecologia.

Brasília, DF 




\section{UNIVERSIDADE DE BRASÍLIA INSTITUTO DE CIÊNCIAS BIOLÓGICAS PROGRAMA DE PÓS-GRADUAÇÃO EM ECOLOGIA}

Dissertação de Mestrado

POLLIANA GOMES LOPES

Alelopatia em Lepidaploa aurea (Asteraceae) como Ferramenta de Restauração Ecológica: Potencial para o Controle de Gramíneas Exóticas Invasoras no Cerrado

Banca Examinadora:

Profa. Dra. Isabel Belloni Schmidt

Presidente/PPGECL UnB

Prof. Dr. Daniel Luis Macias Vieira

Membro titular/PPGECL UnB

Prof. Dr. Fabian Borghetti

Membro titular/PPG-BOT UnB

Dr. Rafael D. Zenni

Membro Suplente/ PPGECL UnB 


\section{Dedicatória}

Dedico este trabalho à memória da minha avó Dionária Marinho Lima, que sinto tanta saudade. Ela adoraria me ver trabalhando com plantas.

“O amor por todas as coisas vivas, é o mais nobre atributo de um homem."

Charles Darwin 


\section{Agradecimentos}

Agradeço primeiramente a Deus, que me deu a graça de passar na seleção deste Mestrado e a força necessária para prosseguir até o fim.

À minha orientadora Isabel Schmidt, por me mostrar um novo mundo (o da Ecologia Vegetal), pela amizade, pelos ensinamentos e pelo comprometimento com a orientação deste projeto.

À Professora Sarah C. Caldas de Oliveira, pelo apoio, participação e constante contribuição neste trabalho. Pela disponibilização do espaço, materiais e equipamentos do Laboratório de Alelopatia do Departamento de Botânica.

À minha amiga Karina Alacid Salles que esteve comigo em todos os momentos, em todas as análises e em todos os perrengues e descobertas deste estudo ao longo destes dois anos. Sem sua ajuda eu não teria conseguido.

Ao Alexandre Sampaio do ICMBio, pela ajuda na concepção e na execução deste trabalho. Pelas dicas nos trabalhos de campo e auxílio na escolha das áreas do experimento.

Ao prof. Daniel Vieira pelas discussões e contribuições que facilitaram o desenvolvimento deste trabalho.

Ao prof. Fabian Borghetti, pela disponibilização do espaço na casa de vegetação do laboratório de Termobiologia do Departamento de Botânica. 
Aos amigos e colegas do grupo Restaura Cerrado, que me auxiliaram nos testes laboratoriais e nos de campo: Andressa, Camila, Monique, Maxmiller, Keiko, Fabiana, Alessandro, Ana Beatriz, Allyne, Karen, Guilherme, Ana Carla, Ana Clara, Maria Paula Antônia, Patrícia, Leonardo e Augusto.

Aos Srs. Manoel, Daniel, Francisco e Antônio do laboratório de Termobiologia, por regarem e cuidarem das minhas plantas nos momentos em que estive ausente.

Ao Aelton Giroldo, pela elaboração dos gráficos.

Ao Instituto Natureza do Tocantins (NATURATINS) pelo afastamento para estudo em outra unidade da federação, que proporcionou o apoio financeiro para a realização deste Mestrado.

Ao CNPq pela bolsa concedida no início do Mestrado.

Aos meus pais, pela educação que me fez chegar onde estou e pelo eterno amor e carinho que me fortalecem em todos os momentos da vida.

Ao meu amor, marido e companheiro de vida, pelo constante apoio, entusiasmo e por estar todos os dias ao meu lado, comemorando minhas vitórias e me levantando nos momentos difíceis.

E aos membros da banca examinadora que aceitaram o convite de avaliar o trabalho. 


\section{Resumo}

Gramíneas africanas são responsáveis por uma série de problemas ecológicos por se tornarem invasoras em muitas partes do mundo, afetando especialmente áreas campestres e savânicas, como no caso do Cerrado. A restauração ecológica por meio de semeadura direta tem se mostrado uma prática eficaz no controle destas gramíneas exóticas invasoras em algumas áreas deste bioma brasileiro. A espécie Lepidaploa aurea (Mart. ex DC.) H. Rob. (Asteraceae) demonstra bom desempenho em projetos de restauração ecológica no Cerrado e aparentemente inibe o crescimento das gramíneas exóticas invasoras Andropogon gayanus e Urochloa decumbens, sem, no entanto, afetar o desenvolvimento de algumas espécies nativas arbóreas, o que indica uma possível atividade alelopática. $\mathrm{O}$ objetivo deste trabalho foi identificar o potencial alelopático de L. aurea sobre as gramíneas exóticas invasoras A. gayanus e U. decumbens, sobre a gramínea nativa: Loudetiopsis chrysothrix, e sobre as arbóreas nativas: Copaifera langsdorffii e Acacia polyphylla, em condições controladas, semi-naturais e naturais. Foram feitos experimentos: (i) em laboratório, com o uso de extratos aquosos de folhas e raizes de L. aurea em placas de Petri, em solo natural (sem esterilização) e esterilizado (para avaliação do efeito da microbiota), e em vermiculita; (ii) em casa de vegetação, com uso de carvão ativado e utilização de solo onde $L$. aurea foi previamente cultivada e de serrapilheira de L. aurea e (iii) em campo, com uso de carvão ativado e avaliação da germinação e do crescimento inicial das plantas-alvo cultivadas dentro e fora de manchas de L. aurea (áreas dominadas pela espécie). Foi constatado o potencial alelopático de L. aurea sobre todas as espécies-alvo (espécies-modelo, exóticas e nativas) em laboratório. Em casa de vegetação, o contato com os aleloquímicos de $L$. aurea reduziu o crescimento inicial da gramínea exótica $U$. decumbens e aumentou o crescimento inicial das espécies nativas C. langsdorffii e L. chrysothrix. Em campo, os efeitos alelopáticos foram observados somente no estímulo à germinação de sementes de C. langsdorffii. A alelopatia em L. aurea pode ser útil em projetos de restauração ecológica por auxiliar no controle da $U$. decumbens e por estimular o melhor desenvolvimento de outras espécies nativas.

Palavras-chave: espécies-alvo, serrapilheira, aleloquímicos, crescimento inicial. 


\section{Abstract}

African grasses are responsible for a number of ecological problems for being invasive in several parts of the world, affecting especially open ecosystems such as grasslands and woodlands as it is the case in the Brazilian savanna, the Cerrado. In these areas, ecological restoration through direct sowing has been shown to be an effective practice in the control of exotic species in some areas of this Brazilian biome. The specie Lepidaploa aurea (Mart. Ex DC.) H. Rob. (Asteraceae) shows good performance in ecological restoration projects in the Cerrado and apparently inhibits the growth of the exotic grasses Andropogon gayanus and Urochloa decumbens, without, however, affecting the development of certain native species tree, indicating a possible allelopathic activity. The aim of this work was to identify the allelopathic potential of $L$. aurea on the exotic grasses A. gayanus and $U$. decumbens, on the native grass Loudetiopsis chrysothrix and on the natives tree Copaifera langsdorffii e Acacia polyphylla under controlled conditions, semi-natural and natural. Experiments were made: (i) in laboratory conditions with the use of water extracts of $L$. aurea $(1.25,2.5,5$ and $10 \%$ concentration) in Petri dishes, in sterilized soil (for evaluation of the effect of microbial) and natural (no sterilization) and vermiculite; (ii) in a greenhouse, with activated carbon and utilization of soil where $L$. aurea was previously grown and $L$. aurea's litter and (iii) in the field, with use of activated charcoal and evaluation of germination and early growth the target plants in and out of patches dominated by $L$. aurea. We found allelopathic effects of L. aurea on all target species (model species, exotic and native) in the laboratory conditions. In the greenhouse, the contact with the allelochemicals of $L$. aurea reduced the initial growth of exotic species $U$. decumbens and increased the initial growth of native species C. langsdorffii and L. chrysothrix. In the field, the allelopathic effects were observed only in increasing the germination of the native tree $C$. langsdorffii. Allelopathy in $L$. aurea can be useful in ecological restoration projects for assisting in the control of $U$. decumbens and encourage better development of other native species.

Keywords: target-species, litter, allelochemicals, early growth 


\section{Sumário}

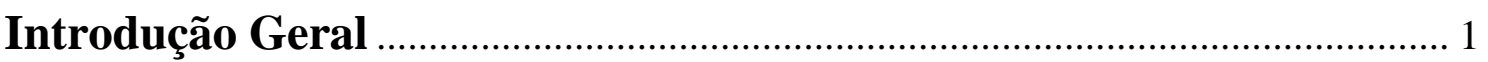

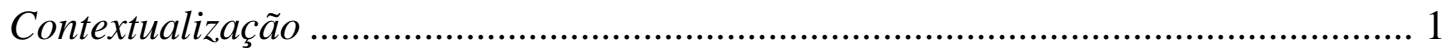

Restauração Ecológica de Áreas Invadidas por Gramíneas Exóticas ......................... 4

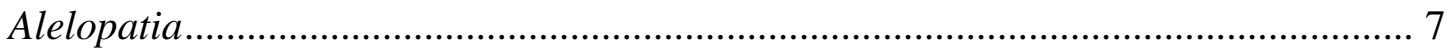

Lepidaploa aurea (Mart. ex DC.) H.Rob. (Asteraceae) ........................................... 13

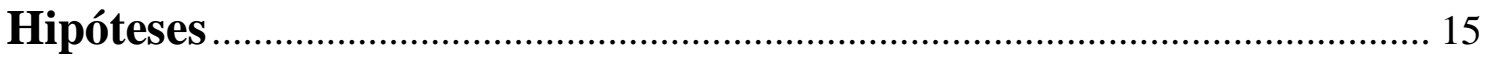

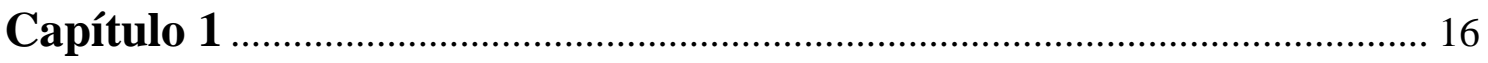

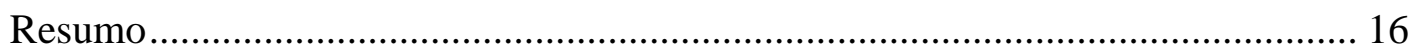

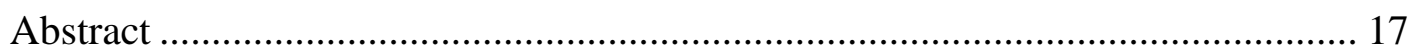

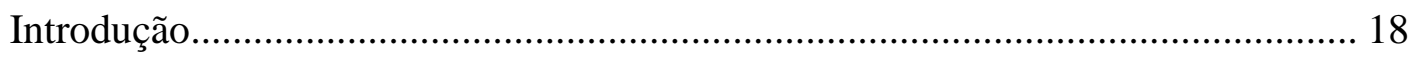

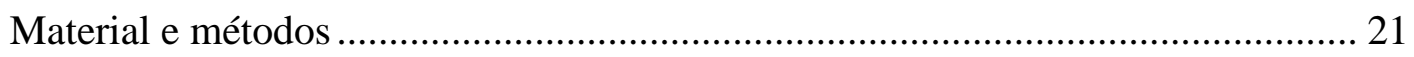

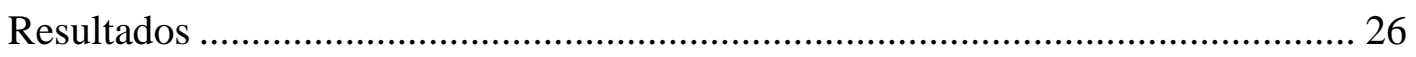

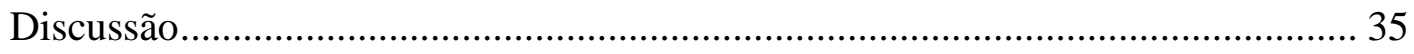

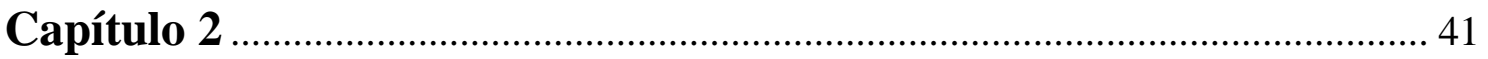

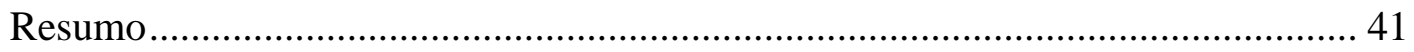

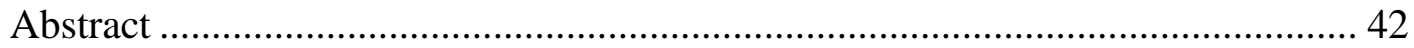




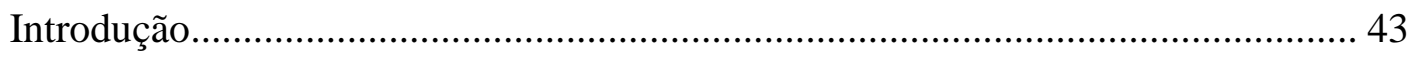

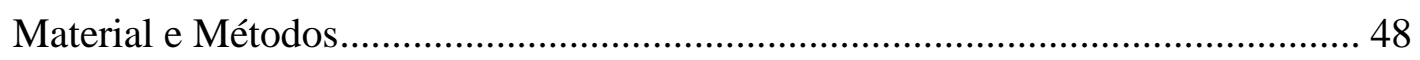

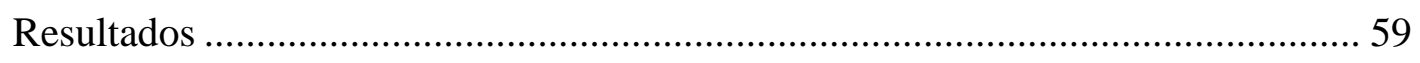

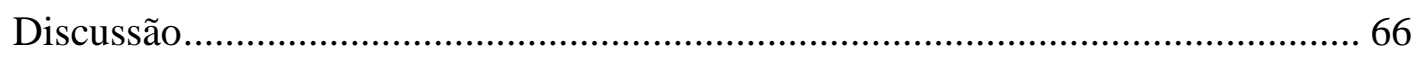

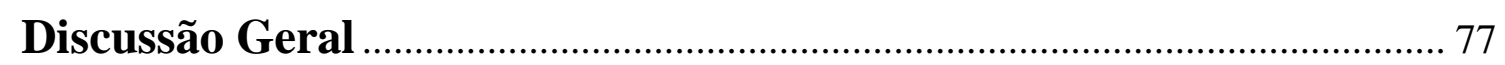

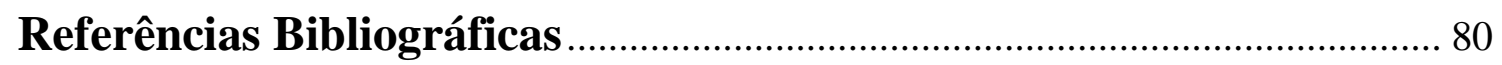




\section{Lista de figuras da Introdução Geral}

Figura 1. (A) Indivíduo de Lepidaploa aurea em campo e (B) Área de plantio de restauração ecológica por meio de semeadura direta dominada pela espécie Lepidaploa aurea, na Reserva Biológica (Rebio) da Contagem, DF.

Figura 2- (A) Camada de serrapilheira em manchas de Lepidaploa aurea (áreas dominadas pela planta) em área de plantio de restauração ecológica e (B) Zona sem cobertura vegetal, especialmente de gramíneas exóticas invasoras, no entorno de manchas de Lepidaploa aurea, onde há a ocorrência de espécies nativas, em áreas de restauração ecológica.

\section{Lista de figuras e tabelas do Capítulo 1}

Figura 1- Plântulas de Lactuca sativa em solo natural com extrato vegetal de Lepidaploa aurea (10 repetições/ concentração de extrato) em laboratório. Todas as plantas-alvo cultivadas em solo natural e esterilizado seguiram o mesmo padrão.

Figura 2- Porcentagem da germinação das espécies-modelo cultivadas em placas de Petri em laboratório pelo período de 5 a 7 dias (dependendo da espécie): (A) com extrato de folha de Lepidaploa aurea e (B) com extrato de raiz de Lepidaploa aurea. As barras representam o valor médio de germinação de cada espécie-alvo em cada tratamento (concentrações de extrato). Diferentes letras indicam as diferenças entre os tratamentos. As análises foram feitas para cada espécie separadamente e letras iguais sobre diferentes espécies não indicam resultados iguais.

Figura 3- Porcentagem da germinação das espécies-modelo cultivadas em laboratório pelo período de 8 a 12 dias (dependendo da espécie): (A) em solo natural com extrato de folha de Lepidaploa aurea e (B) em solo autoclavado com extrato de folha de Lepidaploa aurea. As barras representam o valor médio de germinação de cada espéciealvo em cada tratamento (concentrações de extrato). Diferentes letras indicam as diferenças entre os tratamentos. As análises foram feitas para cada espécie separadamente e letras iguais sobre diferentes espécies não indicam resultados iguais.

Figura 4- Porcentagem de germinação das espécies-modelo cultivadas em laboratório: (A) em solo natural com extrato de raiz de Lepidaploa aurea e (B) em solo autoclavado com extrato de raiz de Lepidaploa aurea. As barras representam o valor médio de germinação de cada espécie-alvo em cada tratamento (concentrações de extrato). Diferentes letras indicam as diferenças entre os tratamentos. As análises foram feitas para cada espécie separadamente e letras iguais sobre diferentes espécies não indicam resultados iguais.

Figura 5- Comprimentos das partes aéreas e radiculares das espécies-modelo cultivadas em placas de Petri em laboratório pelo período de 5 a 7 dias (dependendo da espécie): (A) com extrato de folha de Lepidaploa aurea e (B) com extrato de raiz de Lepidaploa aurea. As barras representam o valor médio de comprimento de cada espécie-alvo em cada tratamento (concentrações de extrato). Diferentes letras indicam as diferenças entre os tratamentos. As análises foram feitas para cada espécie separadamente e letras iguais sobre diferentes espécies não indicam resultados iguais. 
Figura 6- Comprimentos das partes aéreas e radiculares das espécies-modelo cultivadas em laboratório pelo período de 8 a 12 dias (dependendo da espécie): (A) em solo natural com extrato de folha de Lepidaploa aurea e (B) em solo autoclavado com extrato de folha de Lepidaploa aurea. As barras representam o valor médio de comprimento de cada espécie-alvo em cada tratamento (concentrações de extrato). Diferentes letras indicam as diferenças entre os tratamentos. As análises foram feitas para cada espécie separadamente e letras iguais sobre diferentes espécies não indicam resultados iguais.

Figura 7- Comprimentos das partes aéreas e radiculares das espécies-modelo cultivadas em laboratório pelo período de 8 a 12 dias (dependendo da espécie): (A) em solo natural com extrato de raiz de Lepidaploa aurea e (B) em solo autoclavado com extrato de raiz de Lepidaploa aurea. As barras representam o valor médio de comprimento de cada espécie-alvo em cada tratamento (concentrações de extrato). Diferentes letras indicam as diferenças entre os tratamentos. As análises foram feitas para cada espécie separadamente e letras iguais sobre diferentes espécies não indicam resultados iguais.

Figura 8- Sorghum bicolor cultivado em solo natural tratado com extrato de folha de Lepidaploa aurea nas concentrações de 10,00\%, 5,00\%, 2,50\%, 1,25\% e 0\% (controle), respectivamente da esquerda para a direita.

Tabela 1- Tabela de osmolaridade em $\mathrm{mmol} / \mathrm{kg}$ e MPa para várias concentrações de extrato foliar de L. aurea, obtidas em laboratório com o uso do aparelho osmômetro de pressão de vapor osmometer Winscon ${ }^{\circledR} 5.520$.

Tabela 2- Resultados das ANOVA para a avaliação da ação da microbiota sobre os efeitos dos extratos de folha e de raiz de Lepidaploa aurea na germinação das espéciesmodelo em laboratório. As colunas Solo e Extrato indicam o tipo de solo e o tipo de extrato nos quais foram observadas diferenças significativas entre os valores de germinação das espécies-alvo. Foram realizadas ANOVA de dois fatores: Solo (natural ou autoclavado) e Tratamento (concentrações dos extratos).

Tabela 3- Resultados das ANOVA para a avaliação da ação da microbiota sobre os efeitos do extrato de folha de Lepidaploa aurea no comprimento das partes aéreas e radiculares das espécies-modelo em laboratório. A coluna Solo indica o tipo de solo no qual foram observadas diferenças significativas nos valores de comprimento das espécies-alvo. A coluna Parte Afetada indica a parte da planta (se aérea ou radicular) que apresentou diferenças significativas no comprimento conforme o tipo de solo. Foram realizadas ANOVA de dois fatores: Solo (natural ou autoclavado) e Tratamento (concentração de extrato).

Tabela 4- Resultados das ANOVA para a avaliação da ação da microbiota sobre os efeitos do extrato de raiz de Lepidaploa aurea no comprimento das partes aéreas e radiculares das espécies-modelo em laboratório. A coluna Solo indica o tipo de solo no qual foram observadas diferenças significativas nos valores de comprimento das espécies-alvo. A coluna Parte Afetada indica a parte da planta (se aérea ou radicular) que apresentou diferenças significativas no comprimento conforme o tipo de solo. Foram realizadas ANOVA de dois fatores: Solo (natural ou autoclavado) e Tratamento (concentração de extrato). 


\section{Lista de Figuras do Capítulo 2}

Figura 1- Indivíduo de Lepidaploa aurea em área de campo na Rebio da Contagem (DF).

Figura 2- (A) Sementeira de 36 células com vermiculita no interior de bandeja plástica utilizada nos bioensaios laboratoriais e (B) Sementeira com plântulas de Urochloa decumbens cultivadas em vermiculita com extrato foliar de Lepidaploa aurea (tratamento controle - $0 \%$ de extrato) em laboratório.

Figura 3- (A) Vasos com Lepidaploa aurea (6 indivíduos por vaso) em casa de vegetação após seis meses do plantio e (B) Sementeira com 30 sementes (prégerminadas) de Copaifera langsdorffii dispostas em solo no qual $L$. aurea foi previamente cultivada em casa de vegetação (tratamento sem carvão ativado).

Figura 4- Croqui do experimento em campo. Disposição das parcelas em uma mancha de Lepidaploa aurea (áreas dominadas pela espécie). As cinco espécies-alvo: Andropogon gayanus, Urochloa decumbens, Loudetiopsis chrysothrix, Copaifera langsdorffii e Acacia polyphylla, foram plantadas em duas condições (com e sem carvão ativado no solo) em parcelas de $20 \times 20 \mathrm{~cm}$ localizadas dentro de áreas dominadas por L. aurea (no círculo) e fora de áreas dominadas por esta espécie potencialmente alelopática, a no mínimo 3 metros de distância de um indivíduo de L. aurea. Também foram demarcadas parcelas de controle de espontâneas dentro e fora das manchas de Lepidaploa aurea, para evitar erros na contagem de indivíduos, caso ocorresse o surgimento espontâneo de espécies que não foram plantadas.

Figura 5- Urochloa decumbens após cultivo em vermiculita em laboratório: (A) com extrato de folha de Lepidaploa aurea na concentração $0 \%$ (controle), (B) com extrato de folha de L. aurea na concentração $10 \%$.

Figura 6- Urochloa decumbens cultivada em laboratório em vermiculita com extrato de raiz de $L$. aurea nas concentrações de $0 \%$ (controle), 1,25\%, 2,50\%, 5,00\% e 10,00\%, respectivamente da esquerda para a direita.

Figura 7- Comprimento das espécies-alvo cultivadas em vermiculita em laboratório pelo período de 13 dias para as gramíneas e de 18 dias para as espécies arbóreas: (A) com extrato de folha de Lepidaploa aurea e (B) com extrato de raiz de Lepidaploa aurea. As barras representam as médias dos comprimentos das espécies-alvo para cada tratamento (concentrações dos extratos). Diferentes letras representam as diferenças entre os tratamentos. As análises foram feitas para cada espécie separadamente e letras iguais sobre diferentes espécies não indicam resultados iguais.

Figura 8: Comprimento das espécies-alvo cultivadas pelo período de 13 dias para as gramíneas e de 18 dias para as espécies arbóreas, em solo no qual Lepidaploa aurea cresceu durante 9 meses em casa de vegetação, com e sem carvão ativado. As barras representam a média do comprimento das espécies-alvo para cada tratamento (com e sem carvão ativado). Os asteriscos representam diferenças significativas entre os tratamentos. 
Figura 9- (A) Comprimento das espécies-alvo cultivadas por 76 dias em solo coberto com folhas secas de Lepidaploa aurea em casa de vegetação e (B) Biomassa seca das espécies-alvo cultivadas por 76 dias em solo coberto com folhas secas de L. aurea em casa de vegetação. As barras representam a média nos valores de comprimento e biomassa seca das espécies-alvo em cada tratamento (serrapilheira e controles com e sem sombreamento). Diferentes letras representam as diferenças entre os tratamentos. As análises foram feitas para cada espécie separadamente e letras iguais sobre diferentes espécies não indicam resultados iguais.

Figura 10- Percentual de germinação das espécies-alvo cultivadas em campo por 6 meses, dentro e fora de manchas de Lepidaploa aurea (áreas dominadas pela espécie) em parcelas com e sem carvão ativado. As barras representam as médias dos percentuais de germinação das espécies-alvo em cada tratamento (dentro - com carvão, dentro - sem carvão, fora - com carvão, fora - sem carvão). Diferentes letras representam as diferenças entre os tratamentos. As análises foram feitas para cada espécie separadamente e letras iguais sobre diferentes espécies não indicam resultados iguais.

Figura 11- (A) Comprimento das espécies-alvo cultivadas em campo por 6 meses, dentro e fora de manchas de Lepidaploa aurea, em parcelas com e sem carvão ativado. (B) Biomassa seca das espécies-alvo cultivadas em campo por 6 meses, dentro e fora de manchas de $L$. aurea, em parcelas com e sem carvão ativado. As barras representam as médias dos valores de comprimento e de biomassa seca das espécies-alvo em cada tratamento (dentro - com carvão, dentro - sem carvão, fora - com carvão, fora - sem carvão). Diferentes letras representam as diferenças entre os tratamentos. As análises foram feitas para cada espécie separadamente e letras iguais sobre diferentes espécies não indicam resultados iguais.

Figura 12- (A) Urochloa decumbens após plantio em solo no qual Lepidaploa aurea foi previamente cultivada em casa de vegetação (tratamento com carvão ativado) e (B) Urochloa decumbens após plantio em solo no qual Lepidaploa aurea foi previamente cultivada em casa de vegetação (tratamento sem carvão ativado). 


\section{Introdução Geral}

\section{Contextualização}

Em experimentos de restauração ecológica realizados em áreas invadidas por gramíneas exóticas em Unidades de Conservação do Distrito Federal (DF) e de Goiás (GO), Brasil, nos quais foi utilizada a técnica de semeadura direta em área total, com o plantio de espécies nativas do Cerrado de diversas formas de vida (arbóreas, arbustivas, herbáceas e gramíneas), foi observado que a espécie arbustiva Lepidaploa aurea (fig.1) apresenta bom desempenho no estabelecimento e na cobertura de solo (Sampaio et al. 2015) (fig.1). Nas áreas de plantio, especificamente no entorno de locais onde existem adensamentos de indivíduos de $L$. aurea, é possível verificar a existência de uma camada relativamente espessa de serrapilheira durante todo o ano (fig.2), onde foi observada uma significativa redução na ocorrência de outras plantas, especialmente gramíneas e herbáceas, entre elas, as espécies de gramíneas exóticas invasoras Andropogon gayanus e Urochloa decumbens, no entanto, nestas mesmas áreas, algumas espécies nativas aparentemente crescem normalmente, já que é comum a ocorrência especialmente de plântulas de espécies arbóreas também utilizadas nos plantios (fig.2), como por exemplo, Copaifera langsdorffii e Acacia polyphylla, o que sugere possíveis mecanismos de controle específico de espécies de gramíneas e herbáceas, notadamente de gramíneas exóticas invasoras. 

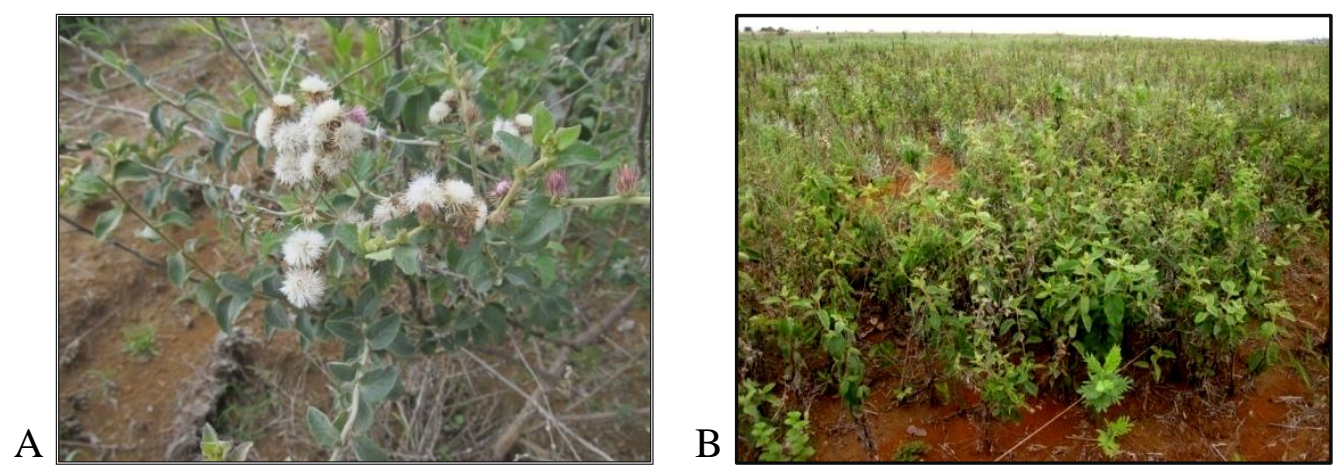

Figura 1- (A) Indivíduo de Lepidaploa aurea em campo e (B) Área de plantio de restauração ecológica por meio de semeadura direta dominada pela espécie Lepidaploa aurea, na Reserva Biológica (Rebio) da Contagem, DF (Foto: Keiko Pellizzaro).
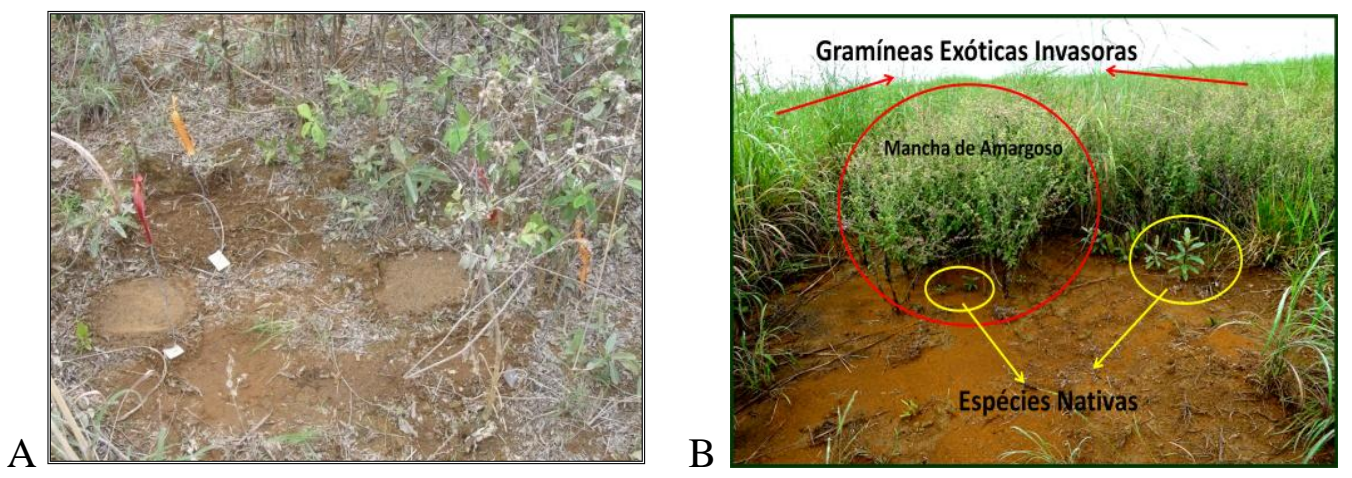

Figura 2- (A) Camada de serrapilheira em manchas de Lepidaploa aurea (áreas dominadas pela planta) em área de plantio de restauração ecológica e (B) Zona sem cobertura vegetal, especialmente de gramíneas exóticas invasoras, no entorno de manchas de Lepidaploa aurea, onde há a ocorrência de espécies nativas, em áreas de restauração ecológica (Foto: Keiko Pellizzaro).

Os padrões de distribuição de espécies ao longo do tempo são influenciados pelos modelos de sucessão ecológica existentes (Johnson 1977). Em áreas de estágios iniciais de sucessão secundária, como é o caso dos locais de plantios recentes realizados por meio de semeadura direta visando a restauração ecológica de áreas perturbadas, é comum observar o modelo denominado inibição, no qual os colonizadores iniciais regulam a sucessão de modo a não permitir a invasão e o crescimento de outras espécies (Cheung et al. 2009, Miranda 2009). No caso específico das áreas de plantios de restauração, os colonizadores iniciais são as espécies pioneiras nativas plantadas, como é o caso da $L$. aurea nos experimentos realizados no Distrito Federal (DF) e em Goiás (GO). 
Nas comunidades vegetais, as plantas podem interagir de maneira positiva ou negativa. Acredita-se que o mais comum seja que plantas vizinhas interajam de forma negativa, de modo que a emergência e/ou o crescimento de uma ou de ambas sejam inibidos (Pires e Oliveira 2011). Muller (1969) denominou como interferência as interações que se desencadeiam entre organismos vizinhos.

A interferência pode englobar vários mecanismos, que foram divididos por Szczepanski (1977) em três tipos gerais: (i) alelospolia ou competição - é a interferência causada pelos organismos que provoca a redução de um ou mais fatores de crescimento ou recursos, e prejudica o desenvolvimento normal de outros organismos na comunidade; (ii) alelomediação ou interferência indireta - é a alteração do ambiente físico ou biológico provocada por alguns organismos, com reflexo nos seres vizinhos; e (iii) alelopatia - interferência provocada por substâncias químicas produzidas por certos organismos que após liberadas no ambiente, afetam os outros componentes da comunidade.

Os três tipos de interferência em geral ocorrem concomitantemente em condições naturais, o que torna a identificação da causa de padrões específicos de distribuição de espécies, como zonas de inibição de crescimento, uma tarefa muito difícil. Separar os efeitos inerentes à cada tipo de interferência tem se mostrado um desafio no mundo todo (Inderjit \& Nilsen 2003, Lankau 2010, Nilsson 1994).

Esta dissertação está centrada em experimentos em três diferentes escalas (laboratório, casa de vegetação e campo) com o objetivo de identificar e compreender possíveis mecanismos de interferência em $L$. aurea, especificamente padrões de alelopatia. 


\section{Restauração Ecológica de Áreas Invadidas por Gramíneas Exóticas}

Espécies exóticas invasoras são espécies introduzidas acidental ou intencionalmente em um novo ambiente, que conseguem se estabelecer e se propagar a grandes distâncias, causando prejuízos ecológicos (Richardson et al. 2000). Quando estas espécies invasoras são plantas, elas podem excluir competitivamente plantas nativas, impedir os processos de sucessão ecológica e alterar o funcionamento dos ecossistemas (Lockwood et al. 2007, Sampaio \& Schmidt 2013, Williams \& Baruch 2000).

As Gramíneas (Poaceae) estão entre as famílias botânicas com maior número de espécies consideradas invasoras (Pivello 2011, Zenni 2014 e 2015). Em ambientes de savana, que se caracterizam pela coexistência de gramíneas, arbustos e árvores, a presença de gramíneas como invasoras em áreas perturbadas é um desafio para a conservação. Algumas espécies de gramíneas possuem atributos que aumentam suas chances de se tornarem invasoras bem sucedidas, entre os principais estão o rápido desenvolvimento, a geração de um grande número de descendentes, a capacidade de interferir no crescimento de plantas ao redor, a facilidade de adaptação às condições diversas e a facilidade de dispersão (D’Antonio \& Vitousek 1992, Kolar \& Lodge, 2001).

Com a expansão agrícola e pecuária, as gramíneas africanas chegaram ao Cerrado brasileiro, local que possui clima semelhante ao das savanas africanas, o que favoreceu o rápido estabelecimento e domínio destas espécies. Desde a sua chegada, com os plantios para formação de pastagens, as gramíneas africanas vêm substituindo extensas áreas de vegetação nativa do Cerrado (Pivello 2011), o que tem provocado uma 
série de consequências negativas para a conservação da biodiversidade deste bioma. Um dos motivos é o fato das gramíneas exóticas serem capazes de alterar significativamente o regime de fogo, aumentando as chances de incêndios que favorecem sua própria manutenção no ambiente, gerando uma retroalimentação positiva (D'Antonio \& Vitousek 1992). Além disso, as gramíneas exóticas invasoras impedem a regeneração natural nas áreas invadidas e expandem sua área de dominância em direção a áreas ocupadas por vegetação nativa (Coutinho 1982, Freitas 1999).

A existência de áreas de Cerrado dominadas por gramíneas exóticas invasoras há várias décadas demonstra que a área e a intensidade da invasão só aumentam com o tempo, impedindo o restabelecimento de espécies nativas. Este quadro só pode ser revertido caso sejam desenvolvidas ações diretas de restauração da área afetada (Horowitz et al. 2013, Martins et al. 2011).

Restauração ecológica é a prática que busca a recuperação da integridade ecológica dos ecossistemas através do resgate do ambiente degradado a um estado mais próximo possível do original, incluindo um nível mínimo de biodiversidade e variabilidade dos processos ecológicos (Society for Ecological Restoration International 2006). Geralmente, a restauração de áreas dominadas por espécies exóticas invasoras é realizada através da remoção das espécies exóticas e a reintrodução das espécies nativas que foram perdidas por alterações da comunidade (Morin 1999). No entanto, esse processo tem se mostrado um desafio em áreas de Cerrado, pois as gramíneas exóticas invasoras, na maioria das vezes, são competitivamente superiores às espécies nativas, afetando, por exemplo, a germinação e o recrutamento das espécies nativas plantadas, através da limitação da luminosidade na superfície do solo. (Sampaio et al. 2015). 
As características de rápido crescimento, estabelecimento e reprodução que são comuns a algumas espécies exóticas invasoras, também são observadas em algumas espécies nativas, especialmente gramíneas e herbáceas consideradas ruderais, como a $L$. aurea. No entanto, espécies nativas ruderais geralmente possuem vida curta e algumas vezes funcionam como espécies pioneiras, iniciando o processo de sucessão ecológica e servindo como facilitadoras do surgimento das espécies intermediárias (Meiners et al. 2012, Miranda 2009).

Para que a prática de restauração ecológica seja de fato eficaz, um dos requisitos importantes é a seleção das espécies que serão utilizadas nos plantios, neste sentido, a identificação de suas características fisiológicas e ecológicas torna-se fundamental; por exemplo, a determinação das taxas de crescimento, das relações competitivas por recursos do meio, e das potencialidades alelopáticas das plantas é essencial para melhor compreender como as espécies interagem em condições de campo, conhecimentos estes que podem se tornar ferramentas importantes no desenvolvimento de resistência ao domínio das espécies exóticas invasoras. (Cummings et al. 2012).

Idealmente, em projetos de restauração ecológica devem ser selecionadas espécies nativas que não só se estabeleçam e cresçam rapidamente, mas que também tenham a capacidade de inibir o desenvolvimento das espécies exóticas concorrentes (Wishnie et al. 2007). Neste sentido, a alelopatia pode ser um mecanismo fundamental pelo qual algumas espécies nativas poderiam reduzir a abundância e o impacto de espécies exóticas invasoras. Portanto, o potencial alelopático de espécies nativas deve ser avaliado juntamente com as taxas de crescimento e outras características funcionais para a seleção de espécies que possam auxiliar processos de restauração ecológica e regeneração natural (Cummings et al. 2012). De fato, existem evidências de que plantas 
nativas com potencial alelopático podem contribuir em processos de restauração ecológica. Algumas leguminosas arbóreas podem ser utilizadas no controle de espécies invasoras, como a Cassia uniflora Mill., que apresentou resultados promissores no controle da espécie invasora Parthenium hysterophorus L. (Asteraceae) na Índia (Srikanth \& Pushpalatha 1991).

A prática de restauração ecológica de áreas dominadas por espécies exóticas invasoras é muitas vezes malsucedida ou mesmo inviabilizada por que algumas técnicas utilizadas são muito onerosas, além de apresentarem uma série de complicações práticas. Portanto, a capacidade das próprias espécies nativas plantadas reduzirem o desenvolvimento das espécies exóticas invasoras, pode ser uma ferramenta de auxílio à viabilização e o êxito dos projetos de restauração (Cummings 2012, Hooper et al. 2002, Jones et al. 2004; Wishnie et al. 2007).

\section{Alelopatia}

A alelopatia é um processo que compreende a liberação por um dado organismo, de substâncias químicas no ambiente, as quais interagem com organismos vizinhos, inibindo ou estimulando o seu crescimento ou desenvolvimento (Ferreira 2004, Rice 1984). Os compostos químicos liberados pelos organismos no ambiente, que afetam os outros componentes da comunidade são denominados aleloquímicos (Pires \& Oliveira 2011, Whittaker 1970).

Os aleloquímicos podem atuar de forma direta sobre outras plantas, sendo absorvidos e agindo sem modificações, ou indiretamente, sofrendo transformações pela microbiota do solo ou alterando propriedades físicas e químicas do solo no qual a planta-alvo está localizada (Cheng 1999, Ferreira 2004, Inderjit 2001, Inderjit \& Dakshini 1999). As substâncias alelopáticas liberadas pelas plantas doadoras por 
lixiviação, volatilização ou degradação do material orgânico podem ser absorvidas pelas plantas receptoras pela epiderme foliar ou pela raiz (Souza Filho \& Alves 2002b).

Geralmente estudos de alelopatia são iniciados com a identificação da fitotoxicidade da planta de interesse em bioensaios laboratoriais, os quais são realizados em ambiente controlado, como placas de Petri em câmaras de germinação, com extratos das plantas doadoras (Wu et al. 2001). Nestes bioensaios, frequentemente são utilizadas plantas denominadas plantas-alvo, as quais são testadas nos estágios iniciais de desenvolvimento (Blum 1999, Fenner 2000), isso por que a fase entre a germinação e a formação das primeiras folhas, estágio chamado de plântula, é o mais sensível à ação de aleloquímicos (Adkins et al. 2007, Fenner 2000)

Alguns autores concordam que os bioensaios em laboratório são ferramentas fundamentais para o estudo prévio do potencial alelopático de plantas (Reigosa et al. 2013, Blum 2011), no entanto, como demonstram apenas evidências de fitotoxicidade, muitas vezes não é considerado adequado se fazer extrapolação dos resultados encontrados em laboratório para condições de campo (Inderjit \& Callaway 2003, Inderjit \& Weston 2000, Lankau 2009).

As condições ambientais em que as plantas são encontradas em campo, como temperatura, umidade e intensidade de luz, em interação com a biota do solo e a disponibilidade de recursos, podem afetar não apenas a produção de aleloquímicos, mas também a estrutura química, o grau de atividade de substâncias liberadas no meio e a sua disponibilidade para as plantas vizinhas (Hadacek 2002, Macías et al. 2007, Reigosa et al. 2013). Pouco se sabe sobre os mecanismos exatos que influenciam as interações planta-planta em condições naturais (Inderjit \& Callaway 2003, Lankau 2009) e pode ser difícil caracterizar a alelopatia e seu verdadeiro impacto, a menos que fatores relacionados à planta, ao solo e aos microorganismos sejam levados em consideração 
(White et al. 1989). De fato, para entender como compostos químicos se tornam alelopáticos, ou seja, como interferem no desenvolvimento de outras plantas, tornam-se necessárias investigações mais aprofundadas, que tenham a finalidade de compreender como os aleloquímicos são produzidos pela planta doadora, qual a concentração e persistência destes compostos no meio ambiente, e qual é o seu envolvimento com a inibição ou estímulo da planta-alvo em campo (Inderjit \& Callaway 2003, Inderjit \& Nilsen 2003, Inderjit \& Weston 2000, Reigosa et al. 2013,).

Entre os diversos fatores que interferem na avaliação do potencial alelopático de plantas em condições naturais, as características relacionadas ao solo têm grande importância, já que o solo é o substrato em que parte significativa das interações alelopáticas entre plantas ocorre (Andrade et al. 2013, Lankau 2010). Em condições naturais os efeitos de aleloquímicos presentes no solo podem ser alterados (Ferreira \& Áquila 2000), uma vez que estes compostos podem ser retidos, transformados pela biota e/ou transportados para outros locais através da percolação promovida pela chuva (Chen 1992).

No intuito de avaliar o potencial alelopático de forma mais próxima às condições naturais, alguns autores recorrem à realização de experimentos em condições seminaturais, que comumente são executados em casas de vegetação, com o plantio de espécies-alvo em vasos preenchidos com solo no qual a planta doadora se desenvolveu em campo ou de solo onde a planta doadora foi previamente cultivada em condições semi-naturais, ou mesmo com a utilização de solo coberto com a serrapilheira da espécie-doadora, previamente coletada em campo (Calaway \& Aschehoug 2000, Cummings et al. 2012). Ainda assim, uma das melhores maneiras de aumentar a garantia dos testes de alelopatia refletirem a condição natural é executar bioensaios in situ. No entanto, um dos principais entraves à execução e interpretação de trabalhos de 
alelopatia em campo, é conseguir separar a ação dos aleloquímicos das diversas interferências ambientais (Ferreira 2004, Inderjit \& Nilsen 2003, Nilsson 1994, Reigosa et al. 2013, Romeo \& Weidenhamer 1996). Outro problema é compreender o sinergismo inerente aos efeitos alelopáticos, uma vez que os aleloquímicos são sempre liberados em combinação com outras substâncias, como íons inorgânicos, hidratos de carbono e aminoácidos (Tang et al. 1995). Blum et al. (1993) sugeriram que os efeitos alelopáticos podem ser resultado da interação de compostos liberados pela planta, alguns que estimulam o crescimento de outras plantas, outros que o inibem e substâncias neutras, como por exemplo, uma mistura de nitrato, compostos fenólicos e glicose, respectivamente.

Um possível mecanismo de atenuação da alelopatia in situ é a adição de carvão ativado ao solo (Inderjit \& Calaway 2003). O carvão ativado é um adsorvente eficiente de compostos bioquímicos, possuindo a capacidade de se ligar aos constituintes orgânicos solúveis em água (alguns dos quais são aleloquímicos), impedindo assim sua solubilização e disponibilidade para as plantas-alvo (Barney et al. 2009, Callaway \& Aschehoug 2003, Inderjet \& Calaway 2003, Jarchow \& Cook 2009, Kabouw et al. 2010, Nolan et al. 2014). Portanto, se as espécies-alvo dos bioensaios apresentam melhor desempenho na presença do carvão ativado, é provável que no solo onde elas foram cultivadas existam aleloquímicos que foram adsorvidos pelo carvão, os quais, promoveram a maior inibição da planta na ausência do carvão ativado. (Inderjit \& Nilsen 2003).

Apesar de o carvão ativado ser um adsorvente de espectro amplo, não há garantias de que ele adsorva todos os produtos químicos com atividades alelopáticas, o que pode causar interpretações errôneas dos experimentos em que não se observa efeitos 
alelopáticos. Adicionalmente, o carvão ativado pode mudar outras características do substrato, como pH ou retenção de água (Nolan et al. 2014).

Uma maneira de reduzir estes problemas e facilitar as interpretações dos resultados de testes de alelopatia em campo com a utilização de carvão ativado, é a realização de bioensaios com espécies-alvo plantadas com e sem carvão ativado em áreas afetadas e não afetadas pela espécie doadora (alelopática). Se a inibição do desenvolvimento das plantas-alvo é reduzida pelo carvão ativado apenas em regiões afetadas pela espécie doadora, então a alelopatia é um provável mecanismo de inibição. No entanto, se as espécies-alvo se desenvolvem melhor na presença de carvão ativado em ambas as regiões afetadas e não afetadas pela espécie doadora, a alelopatia não é um mecanismo provável da inibição observada (Inderjit \& Nilsen, 2003).

A alelopatia também pode ser considerada uma importante característica funcional das espécies vegetais e pode facilitar a compreensão da dinâmica da comunidade (Wardle et al. 1998, Westoby \& Whigth 2006). Apesar de grande parte dos estudos de alelopatia serem iniciados com base em observações de campo, poucos desses estudos consideram a atividade alelopática no contexto da comunidade, já que o mais comum é a realização de testes com espécies-alvo isoladas (Meiners et al. 2014). Portanto, a escolha das espécies-alvo deve ser feita de forma a refletir as interações que acontecem em campo, para que os resultados evidenciem de fato o padrão existente em condições naturais.

Para que a alelopatia seja avaliada de forma mais completa num contexto ecológico, os grupos funcionais das plantas da área de estudo também devem ser levados em consideração (Meiners et al. 2014, Wardle et al. 1998, Westoby \& Wrigth 2006). Chon \& Nelson (2010) discutem que existe um forte componente taxonômico 
para a atividade alelopática e que as espécies da família Asteraceae, em geral, apresentam alto potencial alelopático.

Alguns autores concordam que a alelopatia pode ser considerada um potencial mecanismo de sucessão ecológica (Hils \& Vankat 1982, Kaligaric et al. 2011, Myster \& Pickett 1992), o que foi evidenciado por Meiners et al. (2014) ao demonstrar que a alelopatia em plantas de diferentes formas de vida segue os padrões de dominância comuns aos vários estágios de sucessão, evidenciando que plantas de vida curta, em geral, apresentam maior potencial alelopático do que plantas de vida longa. A alelopatia, nestes casos, provavelmente permite às plantas de vida curta proteção química e maior acesso aos recursos do meio.

A alelopatia já vem sendo estudada no contexto de invasões biológicas a algum tempo. Nestes trabalhos, os autores discutem que o potencial alelopático depende, entre outras coisas, da experiência evolutiva da espécie-alvo, o que fornece uma possível explicação para o motivo das espécies exóticas invasoras apresentarem tanto sucesso no estabelecimento de novas áreas (Barbosa et al. 2008, Callaway \& Aschehoug 2000, Callaway \& Ridenour 2004, Del Fabbro et al. 2014). As espécies exóticas, em geral, não compartilham um histórico evolutivo com as espécies nativas do local, e por esse motivo as plantas nativas não possuem defesas contra os aleloquímicos das novas plantas concorrentes (Barbosa et al. 2008, Callaway \& Aschehoug 2000, Callaway \& Ridenour 2004). Mesmo com as evidências de que a experiência evolutiva das espéciesalvo tem influência na atividade alelopática de plantas, é importante considerar que a alelopatia, antes de mais nada, é uma característica comum tanto às espécies exóticas, quanto às nativas, e como tal, deve ser entendida como um mecanismo geral de dominância de plantas na comunidade, ao invés de ser considerada uma característica única ou mais prevalente em um dos dois tipos de espécies: exóticas e nativas (Meiners 
et al. 2014). Sendo assim, estudos para compreender as diferenças dos efeitos alelopáticos em espécies exóticas e nativas devem considerar não apenas o aspecto coevolutivo das espécies, mas tembém as características funcionais tanto das plantas doadoras como das plantas-alvo.

\section{Lepidaploa aurea (Mart. ex DC.) H.Rob. (Asteraceae)}

A espécie Lepidaploa aurea pertence à família Asteraceae, que compreende aproximadamente 23.000 espécies em 1.535 gêneros e 17 tribos (Judd et al. 2009). Estima-se que cerca da metade das espécies de Asteraceae ocorram no Novo Mundo, com 2.013 espécies na flora brasileira, onde são particularmente abundantes nos ecossistemas de Cerrado, campo rupestre, campo de altitude e restinga (Zappi et al. 2015).

A tribo Vernonieae Cass., com 98 gêneros e cerca de 1.400 espécies, sob o ponto de vista taxonômico, tem sido considerada um dos grupos mais complexos de Asteraceae. Numa série de estudos sobre Vernonieae, Robinson (1987a, 1988a, b, 1990, 1996, 1999) alterou, substancialmente, a circunscrição tradicional de Vernonia, fragmentando-o em diversos novos gêneros. Neste grupo, as folhas são em geral alternas, com venação pinada, capítulos discóides, homógamos e ramos do estilete longos, subulados, com pilosidade se estendendo abaixo do ponto de bifurcação (Bremer 1994).

Originalmente, Cassini (1817 apud King \& Dawson 1975) nomeou Lepidaploa como um subgênero de Vernonia, no entanto, após muitas discussões taxonômicas ao longo de quase 60 anos, Robinson (1990) manteve Lepidaploa no status genérico com base em uma série de características de hábito, indumento, inflorescência, entre outras. 
As espécies do gênero Lepidaploa geralmente possuem porte herbáceo-arbustivo e ocorrem preferencialmente em locais abertos, com alta luminosidade. Além disso, sua propagação em ambientes alterados é favorecida pela produção de um grande número de sementes, e por altas taxas de germinação e de estabelecimento (Farias et al. 2002). Algumas destas espécies possuem um tempo médio de germinação rápido - menos de cinco dias em mais de $70 \%$ das sementes a 20 ou $25^{\circ} \mathrm{C}$ (Ferreira et al. 2001) e em alguns casos, são consideradas ervas daninhas associadas a pastagens e culturas por serem capazes de se estabelecer nestes ambientes. Algumas plantas do gênero possuem a capacidade de colonizar áreas perturbadas, apresentando atributos comuns às espécies ruderais (Lima-Ribeiro \& Prado 2007, Lorenzi 2000).

A espécie Lepidaploa aurea é popularmente conhecida como amargoso e possui uma altura média de 1,3 m (fig 1). É nativa do Brasil e ocorre no bioma Cerrado, especialmente nas vegetações de campo rupestre e Cerrado (lato sensu) (Dematteis \& Almeida, 2015). A fenologia da espécie não é bem documentada, no entanto, nas áreas de plantio por semeadura direta no Distrito Federal e em Goiás, a L. aurea floresce entre os meses de abril e maio, com frutificação entre maio e outubro (Observação pessoal).

Com base nas observações de campo, em adição às várias características funcionais de bom desempenho da $L$. aurea em condições naturais, a identificação do potencial alelopático desta espécie torna-se mais um importante atributo a ser estudado, com vistas a confirmar a espécie como uma boa alternativa para uso em projetos de restauração ecológica no Cerrado.

Esta dissertação tem o objetivo central de avaliar o potencial alelopático de $L$. aurea sobre o crescimento inicial das gramíneas exóticas invasoras: Andropogon 
gayanus e Urochloa decumbens e das espécies nativas: Loudetiopsis chrysothrix, Acacia polyphylla e Copaifera langsdorffii, em condições laboratoriais e em condições semi-naturais (em casa de vegetação). Especificamente, pretende-se: (i) avaliar possíveis efeitos fitotóxicos de $L$. aurea sobre a germinação e crescimento inicial de espécies-modelo em condições laboratoriais, (ii) identificar os principais grupos de compostos químicos em extratos vegetais de $L$. aurea e (iii) avaliar possíveis efeitos alelopáticos de L. aurea sobre a germinação e crescimento inicial das mesmas espéciesalvo exóticas invasoras e nativas testadas em laboratório e casa de vegetação, sob condições de campo.

\section{Hipóteses}

A partir das observações de campo em áreas de plantio de restauração ecológica, foram levantadas as hipóteses a serem testadas neste trabalho: (i) A L. aurea possui potencial alelopático com efeitos inibitórios sobre o desenvolvimento das gramíneas exóticas invasoras: Andropogon gayanus e Urochloa decumbens; (ii) O potencial alelopático de L. aurea apresenta menores efeitos inibitórios sobre as espécies nativas arbóreas: Acacia polyphylla e Copaifera langsdorffii e sobre a gramínea nativa Loudetiopsis chrysothrix. 


\section{Capítulo 1}

\section{Lepidaploa aurea (Asteraceae) - Fitotoxicidade e Influência da Microbiota do Solo em Condições Controladas}

Lopes, P. G; Salles, K, A; Schmidt, I. B; Oliveira, S. C. C; Sampaio, A. B

\section{Resumo}

Alelopatia é o efeito de compostos químicos (aleloquímicos) liberados no ambiente por um organismo sobre o crescimento e/ou desenvolvimento de organismos vizinhos. A partir de observações de campo em áreas de plantio de restauração ecológica, verificouse que Lepidaploa aurea (Asteraceae) pode provocar efeitos alelopáticos, especialmente sobre as espécies de gramíneas exóticas Andropogon gayanus e Urochloa decumbens. Este trabalho objetiva (a) identificar o potencial fitotóxico de L. aurea sobre espéciesmodelo e (b) testar a influência da microbiota do solo sobre estes efeitos fitotóxicos. Foram realizados bioensaios com extratos de folhas e raizes de L. aurea em dois tipos de substrato: papel-filtro em placas de Petri e solo esterilizado (para testar a influência da microbiota) e natural (não esterilizado). Cada bioensaio teve tratamentos com quatro concentrações de extratos aquosos de L. aurea $(10,00 \%, 5,00 \%, 2,50 \%$ e 1,25\%) e um tratamento controle (com água destilada). Foram plantadas sementes das espéciesmodelo: Lactuca sativa (alface), Raphanus sativus (rabanete), Solanum lycopersicum (tomate) e Sorghum bicolor (sorgo) e foram quantificados a germinação e o crescimento inicial aéreo e radicular de cada indivíduo. Em testes de detecção com Cloreto de Ferro, Anisaldeído e Dragendorff foram identificados fenóis, taninos e alcalóides nos extratos de L. aurea. Ambos os extratos causaram redução na germinação e especialmente no crescimento radicular das espécies-modelo, no entanto, os extratos foliares L. aurea tiveram mais influência sobre as espécies-alvo do que os extratos de raizes. A microbiota do solo alterou os efeitos inibitórios de ambos os extratos. A fitotoxicidade em L. aurea pode auxiliar em processos de manejo e conservação de áreas naturais e em projetos de restauração ecológica.

Palavras-chave: crescimento inicial, espécies-modelo, alelopatia, aleloquímicos. 


\title{
Lepidaploa aurea (Asteraceae) - Phytotoxicity and Soil Microbiota
}

\section{Influence of Controlled Conditions}

Lopes, P. G; Salles, K, A; Schmidt, I. B; Oliveira, S. C. C; Sampaio, A. B

\begin{abstract}
Allelopathy is the effect of chemicals released into the environment by an organism on the growth and/or development of neighboring organisms. The released compounds are known as allelochemicals. Field observations in ecological restoration planting areas indicated potential allelopathic effects of Lepidaploa aurea (Asteraceae), especially on exotic grasses Andropogon gayanus e Urochloa decumbens, which are a strong barrier to ecological restoration in the Brazilian savanna (Cerrado). This study aims to (a) identify the phytotoxic potential of $L$. aurea on the model-species and (b) test the influence of soil microbes on such phytotoxic effects. Experiments were performed with leafs and roots extracts of $L$. aurea in two substrate types: paper filter in Petri dishes and sterilized and natural soil (to test the influence of microbiota). For each species and substrate, we used four concentrations of $L$. aurea water extracts $(10 \%, 5 \%, 2.5 \%$ and $1.25 \%)$ and a control (distilled water). The model-species seeds were planted: Lactuca sativa (lettuce), Raphanus sativus (radish), Solanum lycopersicum (tomato) and Sorghum bicolor (sorghum) and were quantified germination and initial shoot and root growth of each individual. In screening tests with Iron Chloride, Anisaldehyde and Dragendorff we identified phenols, tannins and alkaloids in L. aurea extracts. Both extracts cause reduction in germination and root growth especially in the model-species, however, leaf extracts $L$. aurea had more influence on the target species than the roots extracts. The soil microbiota altered the inhibitory effects of both extracts. Phytotoxicity in L. aurea can assist in management processes and conservation of natural areas and ecological restoration projects.
\end{abstract}

Key words: early growth, model-species, allelopathy, allelochemicals. 


\section{Introdução}

A presença de gramíneas exóticas plantadas em áreas de Cerrado para a formação de pastagens é uma das principais causas de desequilíbrios ecológicos neste bioma. Algumas dessas espécies de gramíneas são invasoras agressivas e acabam modificando a paisagem do Cerrado, com a substituição progressiva de suas áreas de vegetação nativa (Pivello 2011). A implementação de projetos de restauração ecológica é uma das maneiras de tentar controlar as invasões por gramíneas exóticas e promover o restabelecimento vegetal nas áreas invadidas. (Horowitz et al. 2013, Martins et al. 2011).

Em plantios de restauração ecológica realizados em Unidades de Conservação do Distrito Federal (DF) e de Goiás (GO), Brasil, foi observado que a planta arbustiva nativa Lepidaploa aurea (Mart. ex DC.) H. Rob. (Asteraceae) com frequência apresenta a ocorrência de zonas de inibição de crescimento de outras plantas em seu entorno, entre as quais, as gramíneas exóticas invasoras Urochloa decumbens e Andropogon gayanus. Nestas zonas, no entanto, é comum a presença de outras espécies nativas, mais especificamente de plântulas de espécies arbóreas também usadas nos plantios de restauração (Sampaio et al. 2015). Este padrão pode indicar mecanismos específicos de controle de gramíneas exóticas invasoras, entre eles uma possível atividade alelopática.

A alelopatia pode ser definida como a interferência positiva ou negativa que compostos do metabolismo secundário produzidos por uma planta exercem sobre outros organismos (plantas, fungos, insetos e algas) (Ferreira 2004, Lovett \& Ryuntyu 1992). Os compostos secundários com atividade alelopática (aleloquímicos) podem estar 
presentes em todas as partes das plantas, como folhas, raizes, frutos, cascas e sementes. No entanto, sua distribuição na planta não é uniforme (Alves et al. 2002).

Atualmente, são conhecidos cerca de 10.000 produtos secundários de plantas com ação alelopática, e estes são considerados apenas uma pequena parte da quantidade possivelmente existente na natureza (Almeida 1991). Alguns dos maiores grupos de compostos químicos com comprovada atividade alelopática são os terpenos, taninos, alcalóides, flavonóides, quinonas e fenilpropanóides, dentre eles as cumarinas e ácidos fenólicos (Chou 2006).

Estudos de alelopatia com espécies nativas em todo o mundo têm tido um aumento expressivo nas últimas duas décadas. Novaes et al. (2013) discutem que no Cerrado 71 espécies tiveram os estudos de alelopatia realizados, representando $0,6 \%$ das 12.000 espécies vasculares do bioma.

Frequentemente a investigação do potencial alelopático de plantas é iniciada em laboratório, com a identificação e o isolamento dos aleloquímicos da planta de interesse, e a avaliação das variações na germinação e no crescimento inicial de plantas-alvo após contato com extratos vegetais da planta doadora (Reigosa et al. 2013, Souza Filho et al. 2010). Nestes testes, em grande parte das vezes, as espécies-alvo são espécies-modelo como o tomate e o rabanete, por se tratarem de espécies cujas sementes são facilmente encontradas e bastante sensíveis a vários aleloquímicos (Ferreira \& Aquila 2000, Pennacchio et al. 2005). Alguns autores defendem que este tipo de teste não identifica o potencial alelopático da planta doadora, mas sim o seu potencial fitotóxico (Allem et al. 2014, Reigosa et al. 2013). O termo alelopatia só deve ser utilizado quando são empregadas metodologias nas quais são atendidos alguns requisitos mínimos de similaridade com as condições naturais, como por exemplo: o uso de extratos aquosos, o 
uso de espécies-alvo que coexistam com a espécie doadora em campo e o uso de substratos mais próximos do encontrado em condições naturais (Blum 2011, Reigosa et al. 2013). No entanto, os bioensaios para identificação da fitotoxicidade da planta doadora são importantes como passo inicial em estudos de alelopatia, já que fornecem os indícios necessários para a continuidade do processo de investigação (Allem et al. 2014).

Em estudos de avaliação da atividade fitotóxica envolvendo o uso de extratos vegetais, cuidados especiais devem ser dispensados para o fator potencial osmótico dos extratos, isso porque a alelopatia e o potencial osmótico apresentam efeitos aditivos, o que leva, em muitos casos, a superestimar os efeitos alelopáticos (Souza Filho et al. 2009). Ferreira \& Aquila (2000) afirmam que um potencial osmótico elevado pode refletir na germinação das sementes atrasando a velocidade de germinação, por exemplo.

Após a comprovação da fitotoxicidade da planta de interesse, caso se planeje prosseguir com o estudo para avaliação do seu potencial alelopático em condições mais próximas à natural, torna-se importante a realização de testes em laboratório com a utilização de solo como substrato, os quais tenham a finalidade de avaliar a ação da microbiota sobre os efeitos dos extratos aquosos da planta doadora. Estes bioensaios, mesmo em carácter preliminar, podem ser usados para posteriores comparações com resultados de testes futuros realizados com a planta doadora em condições semi-naturais e/ou naturais. Ademais, esse tipo de metodologia fornece maior embasamento para a compreensão do papel do solo e de sua microbiota nos efeitos fitotóxicos (Aires et al. 2005, Andrade et al. 2013).

Microorganismos existentes no solo, mesmo em condições controladas, podem influenciar a alelopatia de várias maneiras, seja potencializando os efeitos dos 
aleloquímicos através de sua transformação em subprodutos tóxicos ou reduzindo estes efeitos através da quebra dos compostos em formas menos tóxicas. Os microorganismos podem ainda consumir os aleloquímicos parcial ou completamente (Andrade et al. 2013, Inderjit 2005, Inderjit \& Weston 2000, Lankau 2009). A comparação dos efeitos de solo esterilizado e natural (não esterilizado) na atividade fitotóxica da planta doadora é uma forma eficaz e muito utilizada para quantificar os efeitos da microbiota do solo na bioatividade e estabilidade de substâncias presentes em extratos de plantas e de separar os efeitos biológicos da ação física do solo (Aires et al. 2005, Kaur et al. 2009,).

Com base nas observações de campo em plantios de restauração ecológica no DF e em GO, os objetivos deste trabalho foram: (i) identificar o potencial fitotóxico da Lepidaploa aurea sobre a germinação de sementes e crescimento inicial de quatro espécies-modelo: Lactuca sativa (alface), Raphanus sativus (rabanete), Solanum lycopersicum (tomate) e Sorghum bicolor (sorgo) e (ii) testar a influência da microbiota do solo nestes efeitos fitotóxicos, em condições controladas.

As hipóteses de trabalho são: (i) a Lepidaploa aurea possui efeitos fitotóxicos sobre outras espécies de plantas e (b) a microbiota presente no solo influencia os efeitos fitotóxicos observados.

\section{Material e métodos}

\section{Espécies estudadas}

A espécie doadora Lepidaploa aurea Mart. ex DC. (Asteraceae) é um arbusto nativo do Cerrado muito ramificado de altura média de 1,3 metro, que possui caule com pêlos acinzentados e folhas simples, alternas, de pecíolo curtíssimo e com tricomas nas duas superfícies. É encontrada especialmente em áreas de Cerrado do Brasil central (Farias et al. 2002). 
Como espécies-alvo foram selecionadas quatro espécies-modelo, entre as quais, três são dicotiledôneas: tomate (Solanum lycopersicum, Solanaceae), rabanete (Raphanus sativus, Brassicaceae) e alface (Lactuca sativa, Asteraceae), todas comumente utilizadas em testes laboratoriais de fitotoxicidade (Ferreira e Aquila 2000); e uma monocotiledônea: o sorgo (Sorghum bicolor, Poaceae), que foi escolhida por ser uma espécie muito utilizada como potencial alternativa para estudos alelopáticos preliminares, pois suas sementes são pequenas, de fácil obtenção no mercado, além de apresentarem germinação e crescimento inicial rápido e uniforme (Andrade et al. 2013). Todas as espécies-modelo foram obtidas comercialmente.

\section{Material Vegetal}

Folhas e raizes de L. aurea foram coletadas em áreas de Cerrado no Distrito Federal, Brasil, para produção de extratos. No momento da coleta do material vegetal, foi observado que os indivíduos de $L$. aurea apresentam o sistema radicular relativamente pequeno em condições naturais. No entanto, além dos extratos de folhas de L. aurea, também foi decidido utilizar os extratos de raizes da planta nos bioensaios de fitotoxicidade, com base em metodologias recorrentes em trabalhos semelhantes (Dorning \& Cippolini 2005, Gatti et al. 2010, Moosavi et al. 2011, Wandscheer \& Pastorini 2008) e com vistas à posteriores comparações com resultados de estudos futuros com a L. aurea em condições semi-naturais e naturais.

Para obtenção dos extratos, o material vegetal foi separado, eliminado o excesso de solo (no caso das raizes) e secado em estufa a $60^{\circ} \mathrm{C}$ por 48 horas (Costa \& Pasin, 2015). Depois de seco o material foi triturado em Moinho de Rotor Tipo Ciclone. O pó resultante foi diluído em água destilada na proporção de $10 \mathrm{~g}$ de pó para cada $100 \mathrm{~mL}$ de água destilada e submetido a banho de ultrasson em Lavadora Ultra-Sônica Digital 
por 25 minutos. Em seguida, a solução foi coada com o auxílio de um funil de porcelana, papel filtro de gramatura $80 \mathrm{~g} / \mathrm{m}^{2}$ e uma bomba de vácuo. O resultado foi um extrato a $10 \%$ que foi sendo diluído em água destilada para alcançar as concentrações de $5,00 \%, 2,50 \%$ e $1,25 \%$. O tratamento controle foi feito com água destilada.

A escolha de extratos aquosos para os testes foi selecionada pelo fato de que eles se aproximam mais do que acontece na natureza, já que uma das formas naturais de liberação dos aleloquímicos é através da dissolução pela água da chuva e do orvalho (França et al. 2008).

\section{Testes de detecção de compostos secundários e medição de osmolaridade}

Foram realizados testes de detecção para alguns dos principais grupos de aleloquímicos usando os extratos de folha e de raiz de $L$. aurea a $10 \%$, segundo os protocolos apresentados por Wagner e Bladt (2001) e Atale et al. (2011) com os regentes: (i) Cloreto de Ferro, para detecção de compostos fenólicos e taninos, (ii) Anisaldeído (AS) - ácido sulfúrico, para detecção de terpenos e saponinas e (iii) Dragendorff, para a detecção de alcalóides e compostos heterocíclicos de Nitrogênio.

Foi avaliada a influência do efeito osmótico do extrato foliar de L. aurea. Para isso, primeiramente foi verificada a concentração do extrato por dois procedimentos. $\mathrm{O}$ primeiro para averiguar a quantidade de material solúvel em água presente nas diferentes concentrações $(10,00 ; 5,00 ; 2,50$ e $1,25 \%)$ do extrato foliar, e para isso, 10

mL de cada concentração de extrato foram congelados e em seguida liofilizados, posteriormente foi medida a massa de cada uma das amostras e calculado o valor em ppm para cada uma delas. O segundo procedimento foi medir a osmolaridade dos extratos. Para isso, os extratos de L. aurea nas diferentes concentrações estudadas nos bioensaios: $(1,00 ; 5,00 ; 2,50$ e $1,25 \%)$ tiveram sua osmolaridade medida utilizando um 
osmômetro de pressão de vapor osmometer Winscon ${ }^{\circledR}$ 5.520. Todas as análises foram feitas em triplicatas.

\section{Bioensaios em placas de Petri}

Placas de Petri de $9 \mathrm{~cm}$ de diâmetro foram forradas com papel-filtro (gramatura $80 \mathrm{~g} / \mathrm{m}^{2}$ ) umedecido com os extratos nas concentrações de 10,$00 ; 5,00 ; 2,50$ e 1,25\% e água destilada (controle). Para cada concentração de extrato foram semeadas 40 sementes de cada espécie-alvo, (4 repetições x 10 sementes por placa), perfazendo um total de 200 sementes por espécie. A partir daí, seguiu-se a incubação das placas por 120 horas em câmara de germinação a $25^{\circ} \mathrm{C}$ com fotoperíodo de 12 horas. $\mathrm{O}$ mesmo bioensaio foi utilizado para avaliação da germinação e do crescimento inicial das espécies-alvo. Para o acompanhamento da germinação foi feito o monitoramento das placas a cada 24 horas e após um período 7 dias para $L$. sativa, $R$. sativus e $S$. lycopersicum e de 5 dias para S. bicolor, foi feita a avaliação do crescimento inicial das espécies-alvo, através da medição das suas partes aéreas e radiculares, com a utilização de um paquímetro digital.

\section{Bioensaios em solo}

Foi utilizado como substrato o latossolo vermelho-amarelo peneirado e homogeneizado, esterilizado e natural (sem esterilização). Para a esterilização do solo, foi realizada autoclavagem em três ciclos de 30 minutos a $120^{\circ} \mathrm{C}$. Solo esterilizado e natural foram distribuídos em recipientes perfurados no fundo com capacidade de $40 \mathrm{~g}$ de substrato, os recipientes foram dispostos em caixas plásticas gerbox. Em cada recipiente foi adicionado uma única vez o volume de extrato nas concentrações de 10,$00 ; 5,00 ; 2,50$ e $1,25 \%$ correspondente a $100 \%$ da capacidade de campo do solo 
(previamente determinada), e para o controle foi adicionada a mesma quantidade de água destilada. Nos dois tipos de solo foram semeadas 20 sementes de cada espécie-alvo em cada concentração de extrato (10 repetições x 2 sementes por recipiente), perfazendo um total de 100 sementes/espécie (fig 1). Os experimentos foram mantidos em câmara de crescimento a $25^{\circ} \mathrm{C}$ e fotoperíodo de 12 horas. Foi mantida a capacidade de campo de $100 \%$ do solo nos recipientes com regas diárias, as quais foram realizadas colocandose a água no fundo das caixas de gerbox, assim o solo era irrigado de baixo para cima, evitando a perda excessiva dos extratos por lixiviação.

Após o período de 12 dias de crescimento para L. sativa, $R$. sativus e $S$. lycopersicum e de 8 dias para S. bicolor, os bioensaios foram desmontados e foram consideradas germinadas todas as sementes cujas radículas apresentaram crescimento superior a $2 \mathrm{~mm}$. Para avaliar o crescimento inicial, foram medidos, com paquímetro digital, os comprimentos das partes aéreas e radiculares de cada planta-alvo.



Figura 1- Plântulas de Lactuca sativa em solo natural com extrato vegetal de Lepidaploa aurea (10 repetições/ concentração de extrato) em laboratório. Todas as plantas-alvo cultivadas em solo natural e esterilizado seguiram o mesmo padrão.

\section{Análises Estatísticas}

Os resultados dos testes em placas de Petri foram avaliados por meio de Análises de Variância (ANOVA) considerando os tratamentos (concentração dos extratos) para 
cada espécie e os resultados dos testes em solo foram avaliados através do uso de ANOVA de dois fatores: concentração dos extratos e tipo de solo (esterilizado e natural) para cada espécie. As médias foram comparadas pelo teste de Tukey a 5\% de significância. Os valores de porcentagem de germinação foram transformados em valor angular $(\operatorname{arcoseno} \sqrt{ } \%)$ (Snedecor \& Cochran 1978). As análises foram realizadas no Programa R, versão 3.2.1 (R Development Core Team 2015).

\section{Resultados}

\section{Testes de detecção de compostos e de osmolaridade}

As amostras dos extratos de folhas e de raizes de L. aurea reagiram ao Cloreto de Ferro e ao Dragendorff indicando a presença de fenóis, taninos e alcalóides. Não houve reação ao Anisaldeído, indicando a ausência de terpenos nos extratos testados.

O valor em ppm dos extratos foliares de L. aurea nas concentrações utilizadas nos bioensaios $(10,00 ; 5,00 ; 2,50$ e $1,25 \%)$ podem ser vistos na tabela 1 . Depois de testada a osmolaridade dos extratos foliares de L. aurea nas várias concentrações, observou-se que o extrato apresentou um valor médio de $86,3 \mathrm{mmol} / \mathrm{kg}(-0,23 \mathrm{Mpa})$ para a concentração máxima testada. Esse valor foi comparado com resultados obtidos em testes de osmolaridade feitos anteriormente com a espécie-alvo Sesamum indicum (gergelim), que apresentou a germinação inibida por extratos vegetais somente a partir da osmolaridade de $100 \mathrm{mmol} / \mathrm{kg}$, o que indica que os efeitos dos extratos vegetais de $L$. aurea, mesmo na concentração mais alta utilizada (10\%), não são de natureza osmótica. Resultados de testes de osmolaridade feitos com as espécies-alvo Triticum aestivum (trigo) e Raphanus sativus (rabanete) em extrato de folhas de Drimys brasiliensis, mostrou que não houve inibição da germinação das espécies-alvo em osmolatidade de 0,25 Mpa (Anese et al. 2015). 
Tabela 1- Tabela de osmolaridade em mmol/kg e MPa para várias concentrações de extrato foliar de $L$. aurea. Os resultados foram obtidos em laboratório com o uso do aparelho osmômetro de pressão de vapor osmometer Winscon ${ }^{\circledR} 5.520$.

Extrato foliar em $(\%) \quad$ Valores em ppm $\quad$ Osmolaridade em mmol $/ \mathrm{kg} \quad$ Osmolaridade em MPa

\begin{tabular}{lrrr}
1,25 & 2.205 & 28 & $-0,07$ \\
2,5 & 4.533 & 36 & $-0,09$ \\
5 & 8.227 & 52 & $-0,14$ \\
10 & 15.844 & 86,3 & $-0,23$ \\
\hline
\end{tabular}

\section{Germinação}

Nos bioensaios em placa de Petri o extrato de folha de L. aurea exerceu maior influência sobre a germinação das espécies-modelo do que o extrato de raiz, reduzindo significativamente a germinação de três das quatro espécies-alvo testadas. Somente $S$. bicolor não teve sua germinação afetada pelo extrato foliar. Já o extrato de raiz de $L$. aurea influenciou significativamente a germinação de duas espécies apenas: $L$. sativa e S. lycopercicum $\left(\mathrm{F}_{4},{ }_{15}=8,2, \mathrm{p}=0,001, \mathrm{~N}=40 ; \mathrm{F}_{4},{ }_{15}=11,8, \mathrm{p}=0,0001, \mathrm{~N}=40\right.$; respectivamente) (fig. 2).

Nos experimentos realizados em solo, o extrato foliar de L. aurea somente reduziu significativamente a germinação de $L$. sativa em solo natural na concentração de $5 \%\left(\mathrm{~F}_{4}, 45=3,04 ; \mathrm{p}=0,0267 ; \mathrm{N}=10\right)$ e de $R$. sativus em solo autoclavado na concentração de $10 \%\left(\mathrm{~F}_{4,45}=17,6 ; \mathrm{p}<0,0001 ; \mathrm{N}=10\right)$ (fig. 3). Por sua vez, o extrato de raiz não afetou a germinação de nenhuma espécie-modelo em nenhuma das concentrações em solo autoclavado ou natural (fig. 4). 

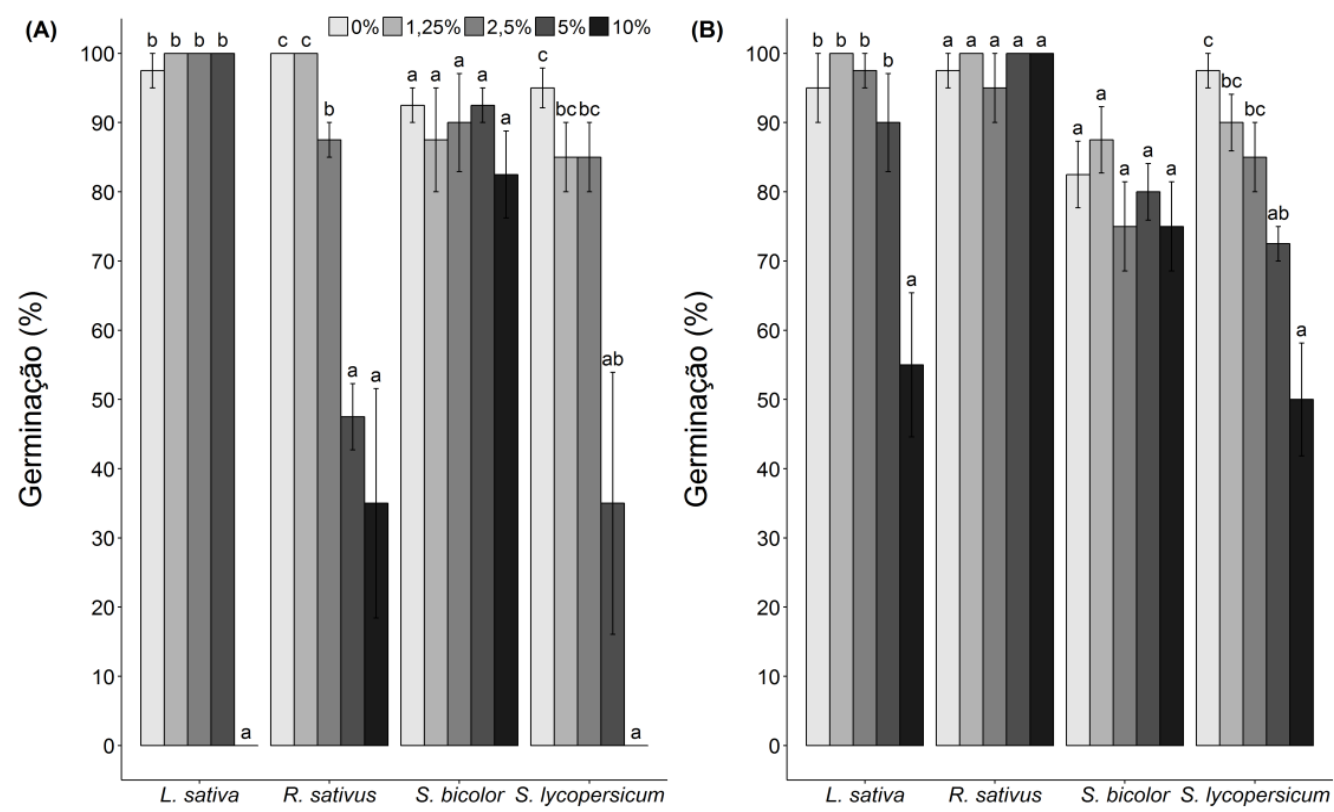

Figura 2- Porcentagem da germinação das espécies-modelo cultivadas em placas de Petri em laboratório pelo período de 5 a 7 dias (dependendo da espécie): (A) com extrato de folha de Lepidaploa aurea e (B) com extrato de raiz de Lepidaploa aurea. As barras representam o valor médio de germinação de cada espécie-alvo em cada tratamento (concentrações de extrato). Diferentes letras indicam as diferenças entre os tratamentos. As análises foram feitas para cada espécie separadamente e letras iguais sobre diferentes espécies não indicam resultados iguais.
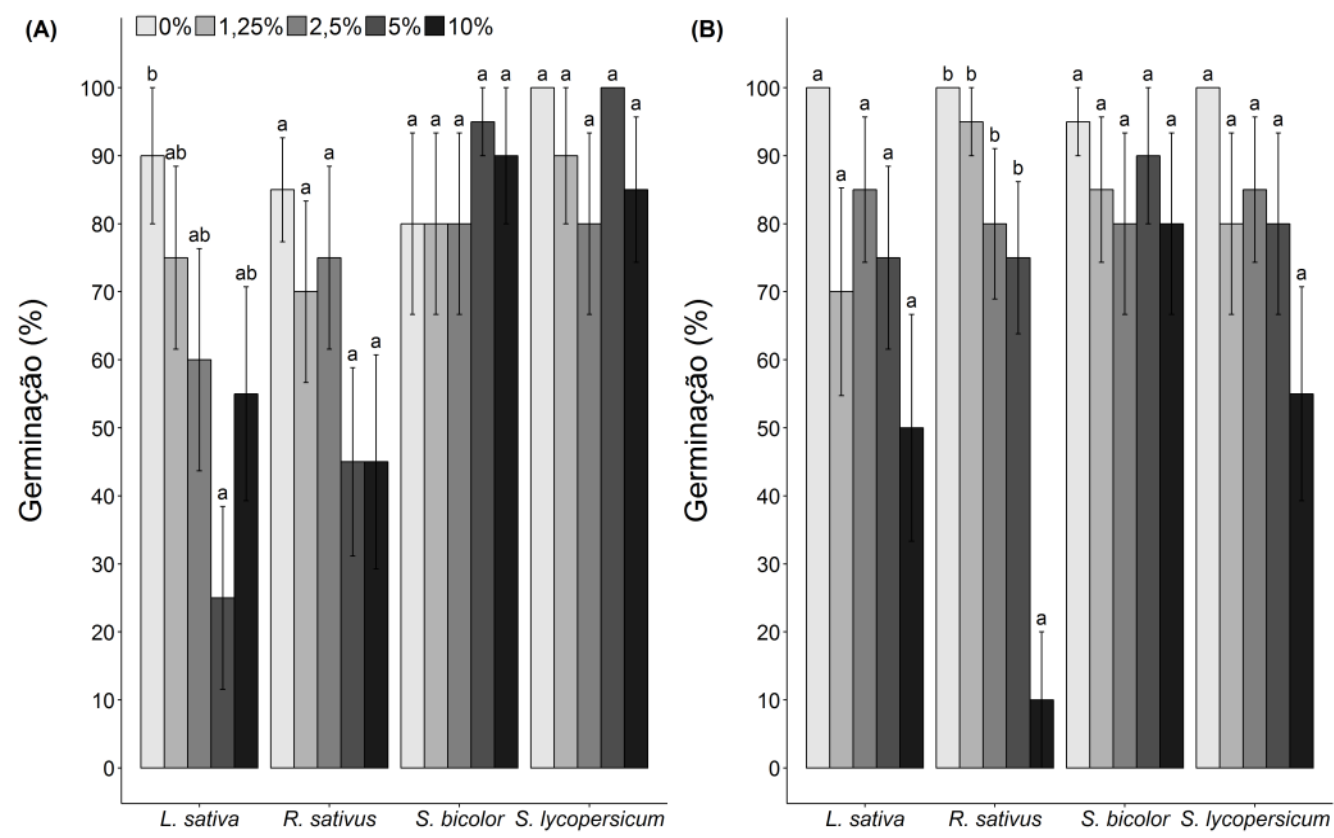

Figura 3- Porcentagem da germinação das espécies-modelo cultivadas em laboratório pelo período de 8 a 12 dias (dependendo da espécie): (A) em solo natural com extrato de folha de Lepidaploa aurea e (B) em solo autoclavado com extrato de folha de Lepidaploa aurea. As barras representam o valor médio de germinação de cada espécie-alvo em cada tratamento (concentrações de extrato). Diferentes letras indicam as diferenças entre os tratamentos. As análises foram feitas para cada espécie separadamente e letras iguais sobre diferentes espécies não indicam resultados iguais. 

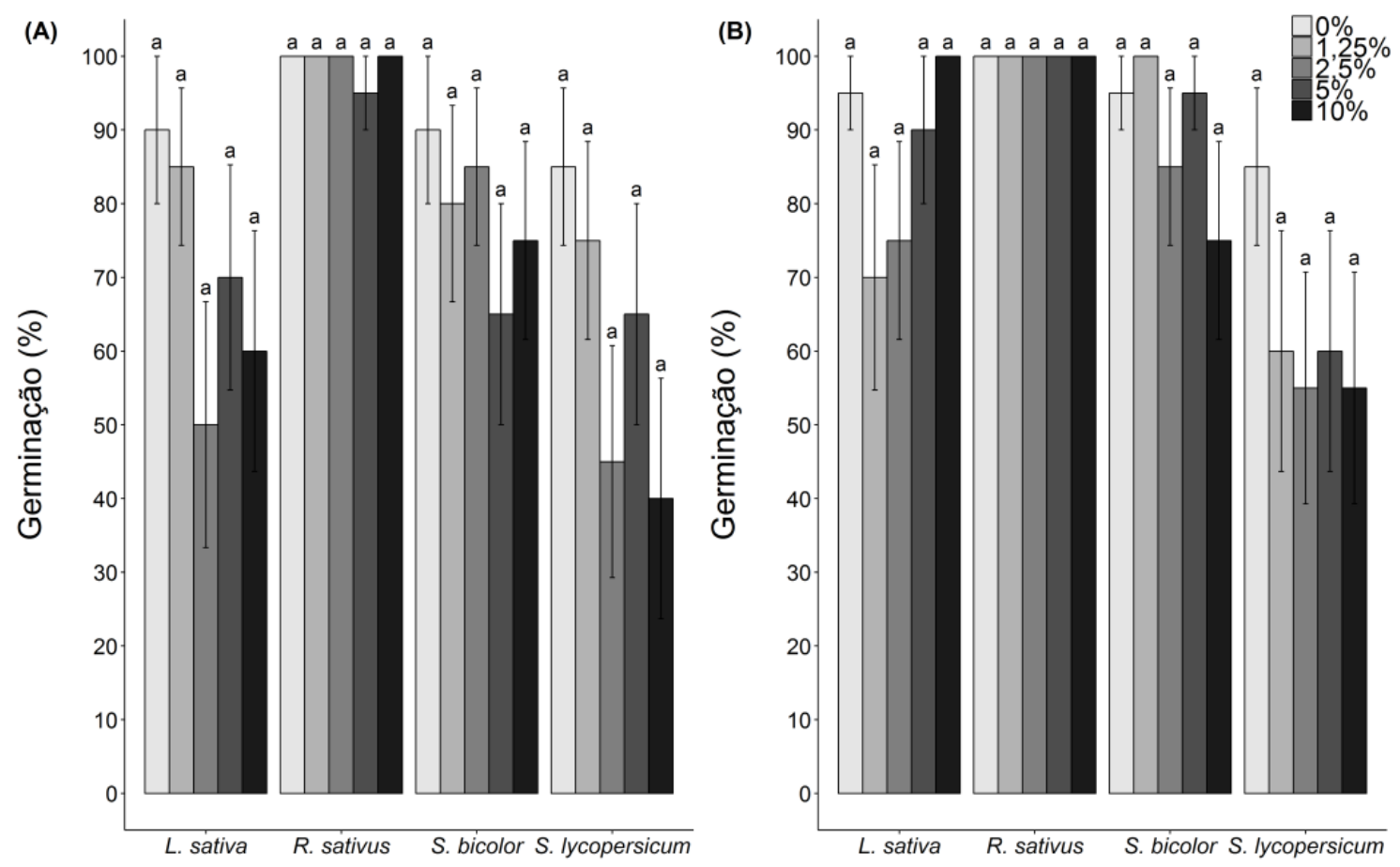

Figura 4- Porcentagem de germinação das espécies-modelo cultivadas em laboratório: (A) em solo natural com extrato de raiz de Lepidaploa aurea e (B) em solo autoclavado com extrato de raiz de Lepidaploa aurea. As barras representam o valor médio de germinação de cada espécie-alvo em cada tratamento (concentrações de extrato). Diferentes letras indicam as diferenças entre os tratamentos. As análises foram feitas para cada espécie separadamente e letras iguais sobre diferentes espécies não indicam resultados iguais.

\section{Crescimento inicial}

Em placas de Petri, o extrato foliar de L. aurea também teve maior influência sobre o crescimento inicial das espécies-alvo do que o extrato de raiz, pois afetou significativamente o crescimento tanto da radícula como da parte aérea de todas as espécies-alvo testadas. Em geral observou-se um padrão de redução do crescimento dose-dependente, ou seja, redução do crescimento conforme o aumento da concentração do extrato foliar. Houve reduções nos comprimentos das radículas em todas as concentrações do extrato foliar (fig. 5). O extrato de raiz de L. aurea influenciou significativamente o crescimento das partes aéreas e radiculares de duas espécies: $L$. 
sativa e $R$. sativus e afetou apenas o crescimento radicular de $S$. bicolor $\left(\mathrm{F}_{4,178}=13,9\right.$; $\mathrm{p}<0,0001 ; \mathrm{N}=40)$ e de $S$. lycopersicum $\left(\mathrm{F}_{4,152}=5,7 ; \mathrm{p}<0,0001 ; \mathrm{N}=40\right)$ (fig. 5).
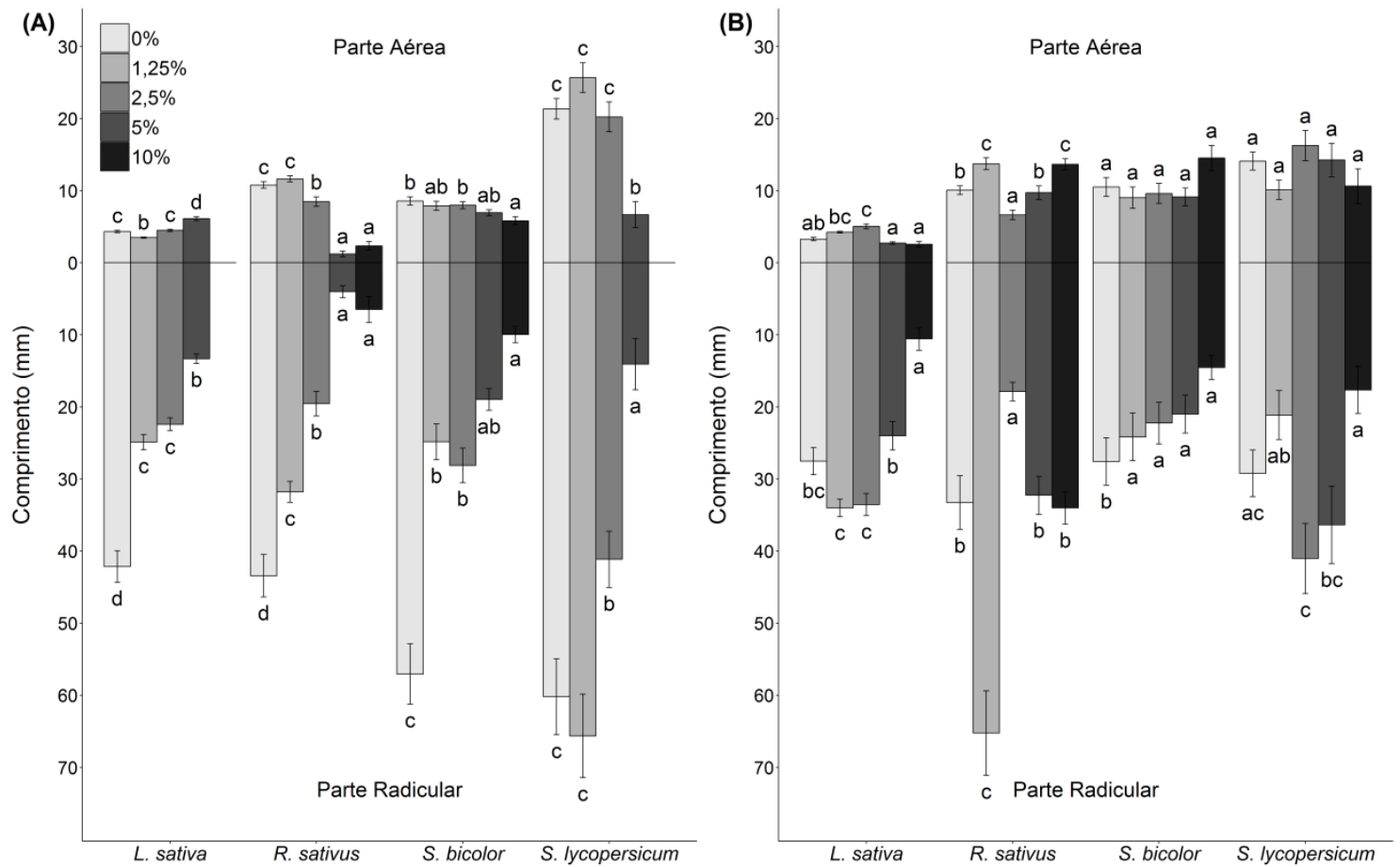

Figura 5- Comprimentos das partes aéreas e radiculares das espécies-modelo cultivadas em placas de Petri em laboratório pelo período de 5 a 7 dias (dependendo da espécie): (A) com extrato de folha de Lepidaploa aurea e (B) com extrato de raiz de Lepidaploa aurea. As barras representam o valor médio de comprimento de cada espécie-alvo em cada tratamento (concentrações de extrato). Diferentes letras indicam as diferenças entre os tratamentos. As análises foram feitas para cada espécie separadamente e letras iguais sobre diferentes espécies não indicam resultados iguais.

O extrato foliar de L. aurea afetou significativamente os crescimentos das radículas e das partes aéreas de $S$. lycopersicum e de $S$. bicolor em solo natural, ambas mostrando padrão de redução do crescimento conforme o aumento da concentração do extrato, mas provocou diferenças no crescimento apenas da parte aérea de L. sativa $\left(\mathrm{F}_{4}\right.$, $\left.{ }_{57}=4,9 ; \mathrm{p}=0,0018 ; \mathrm{N}=20\right)$, sem no entanto, indicar padrão dose-dependente. Por sua vez, a adição do extrato foliar de L. aurea ao solo autoclavado provocou diferenças significativas do crescimento aéreo e radicular de três espécies-modelo: $L$ sativa, $R$. sativus e $S$. lycopersicum. A espécie $S$. bicolor teve somente o crescimento da radícula 
afetado $\left(\mathrm{F}_{4,82}=10,6 ; \mathrm{p}<0,0001 ; \mathrm{N}=20\right)$ pelo extrato foliar em solo autoclavado, observando-se um padrão de redução dose-dependente (fig. 6).
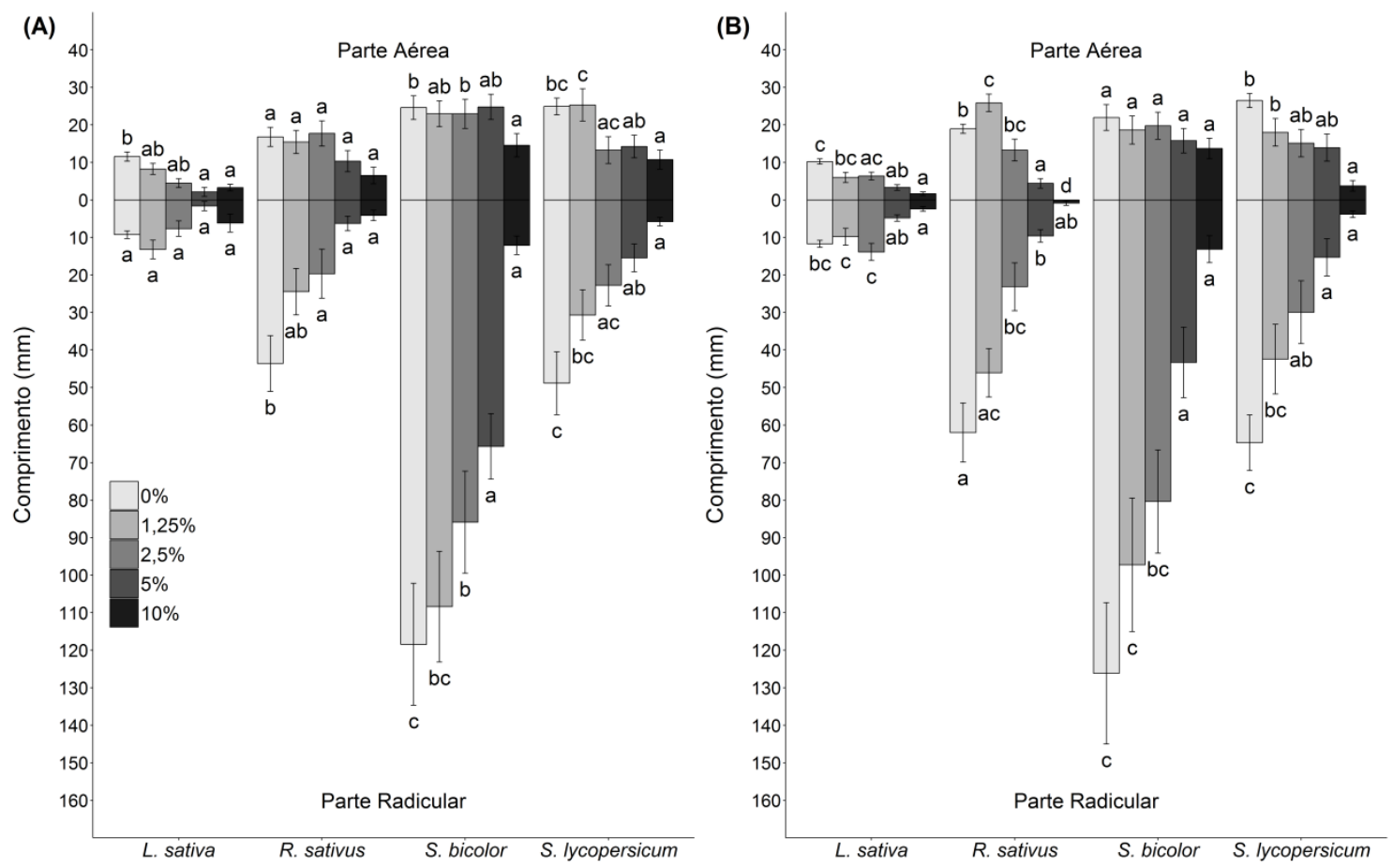

Figura 6- Comprimentos das partes aéreas e radiculares das espécies-modelo cultivadas em laboratório pelo período de 8 a 12 dias (dependendo da espécie): (A) em solo natural com extrato de folha de Lepidaploa aurea e (B) em solo autoclavado com extrato de folha de Lepidaploa aurea. As barras representam o valor médio de comprimento de cada espécie-alvo em cada tratamento (concentrações de extrato). Diferentes letras indicam as diferenças entre os tratamentos. As análises foram feitas para cada espécie separadamente e letras iguais sobre diferentes espécies não indicam resultados iguais.

O extrato de raiz de $L$. aurea em solo natural provocou diferenças significativas de crescimento radicular e aéreo apenas na espécie $L$. sativa (parte aérea: $\mathrm{F}_{4,66}=4,2 ; \mathrm{p}=$ 0,0043; $\mathrm{N}=20$ e parte radicular: $\left.\mathrm{F}_{4}, 65=13,7 ; \mathrm{p}<0,0001, \mathrm{~N}=20\right)$ e do crescimento radicular de S. bicolor. Já em solo autoclavado, o extrato de raiz de L. aurea promoveu a redução do crescimento tanto da parte aérea quanto radicular de S. bicolor (parte aérea: $F_{4,77}=4,6 ; p=0,0022 ; N=20$ e parte radicular: $\left.F_{4,85}=6,1 ; p<0,0001 ; N=20\right)$, mas não afetou significativamente o crescimento da espécie $R$. sativus. A espécie $S$. lycopersicum só apresentou redução significativa do crescimento da parte aérea, 
enquanto L. sativa teve o aumento parte radicular de forma dose-dependente da concentração do extrato de raiz de L. aurea (fig. 7).


Figura 7- Comprimentos das partes aéreas e radiculares das espécies-modelo cultivadas em laboratório pelo período de 8 a 12 dias (dependendo da espécie): (A) em solo natural com extrato de raiz de Lepidaploa aurea e (B) em solo autoclavado com extrato de raiz de Lepidaploa aurea. As barras representam o valor médio de comprimento de cada espécie-alvo em cada tratamento (concentrações de extrato). Diferentes letras indicam as diferenças entre os tratamentos. As análises foram feitas para cada espécie separadamente e letras iguais sobre diferentes espécies não indicam resultados iguais.

\section{Influência da microbiota do solo}

A microbiota do solo não alterou os efeitos dos extratos de L. aurea sobre a germinação da maioria das espécies-alvo. Nos testes com extrato de folha de L. aurea, somente a espécie $R$. sativus apresentou aumento significativo da germinação em solo autoclavado e, nos testes com extrato de raiz, apenas S. bicolor teve mais sementes germinadas em solo natural (tab. 2). As outras espécies-modelo não apresentaram diferenças na germinação ao se comparar o solo natural e o esterilizado. 
Tabela 2- Resultados das ANOVA para a avaliação da ação da microbiota sobre os efeitos dos extratos de folha e de raiz de Lepidaploa aurea na germinação das espécies-modelo em laboratório. As colunas Solo e Extrato indicam o tipo de solo e o tipo de extrato nos quais foram observadas diferenças significativas entre os valores de germinação das espécies-alvo. Foram realizadas ANOVA de dois fatores: Solo (natural ou autoclavado) e Tratamento (concentrações dos extratos).

\begin{tabular}{|c|c|c|c|c|c|c|}
\hline Espécie-modelo & Solo & Extrato & & & & \\
\hline \multirow{4}{*}{$R$. sativus } & \multirow{4}{*}{ autoclavado } & \multirow{4}{*}{ folha } & & G. L & $\mathrm{F}$ & $p(<F)$ \\
\hline & & & Solo & 1,90 & 1,3 & 0,2567 \\
\hline & & & Tratamento & 4,90 & 10,6 & $<0,001$ \\
\hline & & & Solo:Tratamento & 4,90 & 2,7 & 0,034 \\
\hline \multirow[t]{3}{*}{ S. bicolor } & \multirow[t]{3}{*}{ natural } & \multirow[t]{3}{*}{ raiz } & Solo & 1,90 & 6,1 & 0,0152 \\
\hline & & & Tratamento & 4,90 & 1,4 & 0,2407 \\
\hline & & & Solo:Tratamento & 4,90 & 1,4 & 0,2407 \\
\hline
\end{tabular}

Nos bioensaios com extrato de folha, todas as espécies testadas apresentaram diferenças de crescimento se comparados os tipos de solo: $S$. bicolor (parte radicular), $L$. sativa (parte aérea) e $R$. sativus (parte aérea) apresentaram crescimento significativamente maior em solo natural, enquanto S. lycopersicum (parte radicular) apresentou maior crescimento em solo autoclavado (tab. 3). Já nos bioensaios com extrato de raiz de $L$. aurea as espécies $R$. sativus (parte radicular) e $S$. lycopersicum (parte aérea) tiveram crescimento significativamente maior em solo natural e $L$. sativa (parte aérea e radicular) e $R$. sativus (parte aérea) em solo autoclavado (tab. 4). 
Tabela 3- Resultados das ANOVA para a avaliação da ação da microbiota sobre os efeitos do extrato de folha de Lepidaploa aurea no comprimento das partes aéreas e radiculares das espécies-modelo em laboratório. A coluna Solo indica o tipo de solo no qual foram observadas diferenças significativas nos valores de comprimento das espécies-alvo. A coluna Parte Afetada indica a parte da planta (se aérea ou radicular) que apresentou diferenças significativas no comprimento conforme o tipo de solo. Foram realizadas ANOVA de dois fatores: Solo (natural ou autoclavado) e Tratamento (concentração de extrato).

\begin{tabular}{|c|c|c|c|c|c|c|}
\hline Espécie-modelo & Parte afetada & Solo & & ANOVA & & \\
\hline & & & & G.L & $\mathrm{F}$ & $\mathrm{p}(<\mathrm{F})$ \\
\hline \multirow[t]{3}{*}{ L. sativa } & parte aérea & natural & $\overline{\text { Solo }}$ & 1,124 & 6,6 & 0,0112 \\
\hline & & & Tratamento & 4,124 & 9,9 & $<0,001$ \\
\hline & & & Solo:Tratamento & 4,124 & 0,8 & 0,5406 \\
\hline \multirow[t]{3}{*}{ R. sativus } & parte aérea & natural & Solo & 1,114 & 0,4 & 0,5239 \\
\hline & & & Tratamento & 4,114 & 4,8 & 0,0012 \\
\hline & & & Solo:Tratamento & 3,114 & 3,4 & 0,0212 \\
\hline \multirow[t]{3}{*}{ S. bicolor } & parte radicular & natural & Solo & 1,161 & 8,4 & 0,0044 \\
\hline & & & Tratamento & 4,161 & 22,9 & $<0,001$ \\
\hline & & & Solo:Tratamento & 4,161 & 0,1 & 0,9665 \\
\hline \multirow[t]{3}{*}{ S. lycopersicum } & parte radicular & autoclavado & Solo & 1,149 & 7,3 & 0,0076 \\
\hline & & & Tratamento & 4,149 & 15,8 & $<0,001$ \\
\hline & & & Solo:Tratamento & 4,149 & 0,6 & 0,6326 \\
\hline
\end{tabular}

Tabela 4- Resultados das ANOVA para a avaliação da ação da microbiota sobre os efeitos do extrato de raiz de Lepidaploa aurea no comprimento das partes aéreas e radiculares das espécies-modelo em laboratório. A coluna Solo indica o tipo de solo no qual foram observadas diferenças significativas nos valores de comprimento das espécies-alvo. A coluna Parte Afetada indica a parte da planta (se aérea ou radicular) que apresentou diferenças significativas no comprimento conforme o tipo de solo. Foram realizadas ANOVA de dois fatores: Solo (natural ou autoclavado) e Tratamento (concentração de extrato).

\begin{tabular}{|c|c|c|c|c|c|c|}
\hline Espécie-modelo & Parte afetada & Solo & & ANOVA & & \\
\hline & & & & G. L & $\mathrm{F}$ & $\mathrm{p}(<\mathrm{F})$ \\
\hline \multirow[t]{6}{*}{ L. sativa } & parte aérea & autoclavado & Solo & 1,146 & 0,02 & 0,8837 \\
\hline & & & Tratamento & 4,146 & 1,3 & 0,2751 \\
\hline & & & Solo:Tratamento & 4,146 & 3,5 & 0,0089 \\
\hline & parte radicular & autoclavado & Solo & 1,144 & 27,3 & $<0,001$ \\
\hline & & & Tratamento & 4,144 & 15,5 & $<0,001$ \\
\hline & & & Solo:Tratamento & 4,144 & 0,2 & 0,9231 \\
\hline \multirow[t]{6}{*}{ R. sativus } & parte aérea & autoclavado & Solo & 1,168 & 7,5 & 0,0069 \\
\hline & & & Tratamento & 4,168 & 2,5 & 0,0446 \\
\hline & & & Solo:Tratamento & 4,168 & 1,7 & 0,1418 \\
\hline & parte radicular & natural & Solo & 1,189 & 0,5 & $\overline{0,4941}$ \\
\hline & & & Tratamento & 4,189 & 0,1 & 0,4132 \\
\hline & & & Solo:Tratamento & 4,189 & 4,2 & 0,0029 \\
\hline \multirow[t]{3}{*}{ S. lycopersicum } & parte aérea & natural & Solo & 1,112 & 18 & $<0,001$ \\
\hline & & & Tratamento & 4,112 & 5,4 & $<0,001$ \\
\hline & & & Solo:Tratamento & 4,112 & 1,8 & 0,132 \\
\hline
\end{tabular}




\section{Discussão}

Os extratos de L. aurea provocaram efeitos menos evidentes sobre a germinação do que sobre o crescimento inicial das espécies-modelo. Muitos trabalhos indicam que a germinação é um parâmetro pouco sensível à presença de aleloquímicos, se comparada ao crescimento inicial, por isso, experimentos de germinação em estudos de alelopatia frequentemente são vistos com ressalva (Candido et al. 2010, Ferreira e Borghetti 2004, Inderjit \& Dakshini 1995), contudo, é um critério comumente utilizado em pesquisas sobre fitotoxicidade ou alelopatia, devido à importância de se averiguar o efeito alelopático em diferentes processos fisiológicos, já que os aleloquímicos agem de diversas maneiras sobre o desenvolvimento das plantas-alvo (Candido et al. 2010, Ferreira e Borghetti 2004, Inderjit \& Dakshini 1995, Silva 2004).

O padrão geral de respostas das espécies-alvo aos extratos de $L$. aurea, de redução dose-dependente da concentração, demonstra que os extratos provocaram a inibição das espécies-modelo, especialmente do seu crescimento radicular (fig. 8). A sensibilidade radicular aos aleloquímicos é bem documentada em literatura, sendo uma das características que melhor indica a ação fitotóxica de extratos vegetais (Burgos et al. 2004, Ferreira \& Aquila 2000, Koitabashi et al. 1997). Alguns trabalhos relatam que o efeito mais acentuado sobre o crescimento das raizes pode ter relação com o maior contato desta parte da planta com o substrato embebido da solução de extrato (Chung et al. 2001, Maraschin-Silva e Aquila 2006). 


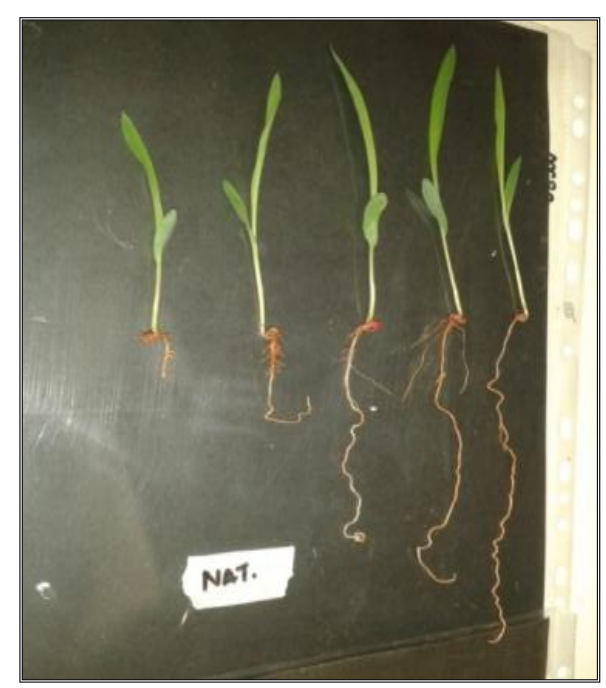

Figura 8- Sorghum bicolor cultivado em solo natural tratado com extrato de folha de Lepidaploa aurea nas concentrações de $10,00 \%, 5,00 \%, 2,50 \%, 1,25 \%$ e $0 \%$ (controle), respectivamente da esquerda para a direita.

Também foi observado que a germinação e o crescimento inicial das espéciesalvo foram mais sensíveis ao extrato de folha do que ao extrato de raiz de $L$. aurea, em ambas as condições testadas, o que pode ser explicado pelo fato de $L$. aurea produzir grande quantidade de folhas na estação chuvosa, as quais são liberadas no solo na estação seca, formando uma camada de serrapilheira relativamente densa, que permanece abaixo das plantas durante todo o ano. Esta característica, em adição ao fato de L. aurea possuir um sistema radicular relativamente pequeno, pode indicar que a planta investe mais na produção de aleloquímicos localizados em suas folhas.

As espécies-modelo não apresentaram um padrão claro de respostas de germinação e de crescimento inicial em relação ao substrato utilizado, algumas apresentando efeitos mais ou menos acentuados em placa de Petri do que em solo e vice-versa. Estes resultados reforçam o entendimento de que em estudos de fitotoxicidade e/ou alelopatia é importante analisar diferentes espécies-alvo em diferentes condições, já que a susceptibilidade a um determinado aleloquímico varia 
entre espécies, entre indivíduos de uma mesma espécie e entre diferentes condições testadas (An et al. 1997, Oliveira et al. 2014).

Ao se comparar o desenvolvimento inicial das espécies-alvo dicotiledôneas e da monocotiledônea $S$. bicolor, observou-se que a monocotiledônea foi a única espécie que não apresentou a germinação afetada pelos tratamentos com os extratos vegetais de $L$. aurea, em nenhum dos tipos de substratos utilizados. Resultados similares foram observados por Azevedo Neto (2010) que estudou os efeitos de extratos aquosos foliares de Leucaena leucocephala sobre a germinação e o crescimento inicial de $S$. bicolor. Trabalhos comparando respostas de espécies-modelo dicotiledôneas e monocotiledôneas à ação de extratos vegetais não são bem documentados, todavia, existe uma grande quantidade de trabalhos que demonstram que a germinação de monocotiledôneas é afetada pela exposição a extratos aquosos de certas plantas (Turk e Tawaha 2003, Belinelo et al. 2008), padrão de respostas oposto ao encontrado neste trabalho.

Apesar das diferenças nas respostas de germinação e de crescimento inicial das espécies-alvo em relação ao tipo de extrato e ao substrato utilizado nos bioensaios laboratoriais, todas as espécies-modelo tiveram o desenvolvimento inicial influenciado de alguma forma pela presença dos aleloquímicos da $L$. aurea, especialmente na presença dos compostos alelopáticos de origem foliar, o que corrobora a primeira hipótese do trabalho de que a $L$. aurea apresenta efeitos fitotóxicos sobre as espéciesalvo.

A ação microbiana não apresentou um padrão claro de redução ou de potencialização dos efeitos inibitórios dos extratos de $L$. aurea. Nos bioensaios com 
extrato de folha a microbiota do solo atuou reduzindo os efeitos inibitórios dos extratos sobre a maioria das espécies-alvo, provavelmente quebrando os compostos em formas menos tóxicas ou simplesmente consumindo-os. Todavia, a microbiota também potencializou os efeitos inibitórios do extrato foliar em alguns casos, como por exemplo, sobre a germinação de $R$. sativus. Por sua vez, a ação microbiana reduziu os efeitos inibitórios do extrato de raiz de $L$. aurea sobre o crescimento inicial de $L$. sativa e de $R$. sativus (parte aérea) e sobre a germinação de S. bicolor, e potencializou-os sobre o crescimento de $S$. lycopersicum e de $R$. sativus (parte radicular). Em contato com o extrato de raiz de $L$. aurea a espécie $R$. sativus apresentou maior crescimento da parte aérea em solo natural e da radícula em solo autoclavado, o que sugere que possivelmente a redução da parte radicular desta espécie na presença da microbiota tenha sido compensada com o aumento do seu crescimento aéreo, sob estas condições.

Ademais, não se constatou um padrão das partes das plantas que tiveram o crescimento mais afetado pela presença da microbiota. A presença dos microorganismos alterou os efeitos de ambos os extratos sobre o crescimento aéreo e radicular das plantas-alvo, na mesma proporção. Estas observações demonstram que possivelmente a ação microbiana no solo é dependente do tipo de extrato e das características das espécies utilizadas nos bioensaios (Andrade et al. 2013). Para melhor compreender a amplitude da atividade microbiana, mesmo que em caráter preliminar, seriam necessários estudos mais aprofundados, que levem em consideração a estrutura química dos extratos, bem como a fisiologia das plantas-alvo.

Ao se avaliar o efeito da microbiota do solo sobre extratos vegetais de plantas utilizando a metodologia de autoclavagem do substrato, é importante ter em mente que neste processo de esterilização do solo, a biomassa dos microorganismos que foram 
mortos permanece no substrato, o que possivelmente aumenta a quantidade de nutrientes disponíveis às plantas-alvo. Portanto, maiores números de sementes germinadas e/ou maior crescimento inicial das plantas-alvo em solo autoclavado podem significar um ambiente mais nutritivo, o que pode interferir na avaliação da ação microbiana sobre os efeitos dos extratos vegetais de $L$. aurea.

Apesar dos diferentes efeitos da ação microbiana sobre os extratos de L. aurea, a segunda hipótese do trabalho foi corroborada, já que de fato, a microbiota do solo influenciou a fitotoxicidade de L. aurea. Esse resultado é importante para compreender que a fitotoxicidade em plantas é sensível a fatores externos, neste caso, à ação da microbiota do solo. Portanto, se houve sensibilidade a fatores externos em condições controladas, é provável e quase certo que o potencial alelopático de $L$. aurea em condições naturais seja dependente de fatores relacionados às condições ambientais existentes no local de estudo.

Os efeitos dos extratos de L. aurea sobre as espécies-modelo possivelmente são resultado da ação dos grupos de compostos químicos identificados (fenóis, taninos e alcalóides), visto que de fato foram confirmados efeitos fitotóxicos na germinação de sementes e no crescimento inicial das plantas-alvo. No entanto, seria necessário o uso de técnicas mais sofisticadas de análise química, como a cromatografia líquida e outras, para identificar quais compostos estão presentes e suas concentrações nos extratos, uma vez que uma grande quantidade de compostos químicos estão englobados nos grupos detectados (Santos et al. 2011, Souza Filho 2002).

Estudos de fitotoxicidade e alelopatia podem se tornar ferramentas úteis e aplicáveis em uma série de áreas. Já está bem estabelecido que os compostos secundários de plantas possuem uma grande importância econômica, pois são utilizados 
de formas variadas, que vão desde produtos farmacológicos, corantes, até pesticidas ou herbicidas. (Macías et al. 2007).

Pesquisas de alelopatia com enfoque ecológico, mesmo que em caráter prévio, podem auxiliar em ações de conservação e manejo de áreas naturais (Bensusan 2006). Durigan (2008) aponta que o conhecimento dos processos ecológicos (dentre eles a alelopatia), dos processos sucessionais e do ciclo de vida das plantas são de grande importância para a conservação de áreas naturais.

No caso específico da restauração ecológica de áreas naturais que foram invadidas por gramíneas exóticas, a alelopatia em espécies nativas pode servir como auxílio ao controle das espécies invasoras (Cummings 2012). Sendo assim, a identificação da fitotoxicidade em $L$. aurea pode servir de base para estudos mais aprofundados que visem avaliar o potencial alelopático desta espécie em condições mais próximas da natural, utilizando como espécies-alvo as espécies exóticas e nativas que coexistem com a planta em campo.

O padrão de distribuição de espécies observado em áreas de plantio de restauração ecológica no Cerrado do DF e de GO poderia ser, em parte, explicado pelo potencial alelopático de L. aurea com efeitos inibitórios mais fortes em gramíneas exóticas invasoras do que em espécies nativas e a identificação deste comportamento em L. aurea poderia confirmar a espécie como uma boa alternativa para uso em projetos de restauração ecológica de áreas invadidas por gramíneas exóticas no Cerrado. 


\section{Capítulo 2}

\section{Alelopatia em Lepidaploa aurea (Asteraceae) - Ferramenta de Auxílio à Restauração Ecológica do Cerrado}

Lopes, P. G; Salles, K, A; Schmidt; I. B; Oliveira, S. C. C; Sampaio, A. B.

\section{Resumo}

Grande parte das áreas naturais do Cerrado estão sendo convertidas em pastagens de gramíneas africanas, que estão entre as principais espécies exóticas invasoras (EEI) em todo o mundo. Uma das práticas de controle de EEI em áreas degradadas é a restauração ecológica, que visa reconstituir o ambiente degradado o mais próximo possível do seu estado original. Em projetos de restauração ecológica no Cerrado, a espécie Lepidaploa aurea (Mart. ex DC.) H. Rob. (Asteraceae) se destaca por seu sucesso de estabelecimento e aparente inibição do crescimento das gramíneas exóticas invasoras Andropogon gayanus e Urochloa decumbens, o que pode indicar potencial alelopático. O objetivo do trabalho foi identificar o potencial alelopático de L. aurea sobre as EEI e sobre espécies nativas (uma gramínea e duas arbóreas) em condições controladas, seminaturais e naturais. Foram feitos experimentos: (i) em laboratório, com o uso de extrato vegetal de L. aurea; (ii) em casa de vegetação, com uso de carvão ativado e utilização de solo onde $L$. aurea foi previamente cultivada e de serrapilheira de $L$. aurea e (iii) em campo, com uso de carvão ativado e avaliação da germinação e crescimento inicial de espécies-alvo plantadas dentro e fora de áreas dominadas por indivíduos de L. aurea. Foi constatado o potencial alelopático de L. aurea em laboratório sobre todas as espécies-alvo, em casa de vegetação sobre $U$. decumbens e sobre as espécies nativas Copaifera langsdorffii e Loudetiopsis chrysothrix, todavia, em campo, os efeitos alelopáticos foram observados somente no aumento da germinação da espécie $C$. langsdorffii. A alelopatia em L. aurea pode auxiliar projetos de restauração ecológica, na escolha de técnicas mais baratas e eficazes de controle de $U$. decumbens e na seleção de plantas nativas a serem utilizadas em plantios de restauração.

Palavras-chave: espécies-alvo, aleloquímicos, gramíneas exóticas invasoras. 


\title{
Allelopathy in Lepidaploa aurea (Asteraceae) - A Possible Tool to
}

\section{Cerrado Ecological Restoration}

Lopes, P. G; Salles, K, A; Schmidt; I. B; Oliveira, S. C. C; Sampaio, A. B.

\begin{abstract}
Large natural areas of the Brazilian savanna (Cerrado) have been converted to pastures planted with African grass species, which are among the major invasive alien species (IAS) worldwide. One of the control practices of IAS in degraded areas involves ecological restoration, which aims to bring degraded areas to restored states, as close as possible to the original state. In restored areas within the Cerrado, Lepidaploa aurea (Mart. Ex DC.) H.Rob. (Asteraceae) stands out for its successful establishment and for an apparent inhibition the growth of exotic grasses Andropogon gayanus and Urochloa decumbens, which may indicate allelopathic potential. The objective of this work was to identify L. aurea allelopathic effects on IAS and on native species (one grass and two woody) under controlled, semi-natural and natural conditions. Experiments were carried out: (i) in the laboratory, with different concentrations of L. aurea extracts (from 1.25, 2.5, 5 e 10\%); (ii) in the greenhouse, with use of activated charcoal and using soil where L. aurea was previously grown and $L$. aurea litter and (iii) in field conditions with activated carbon use to evaluate seed germination and early growth of the target-species inside and outside areas dominated by $L$. aurea. We found allelopathic potential of $L$. aurea in the laboratory on all target-species, in the greenhouse on $U$. decumbens and on native species Copaifera langsdorffii and Loudetiopsis chrysothrix, however, in the field, the allelopathic effects were observed only through an increased seed germination rate for the native tree C. langsdorffii. Allelopathy in L. aurea can help ecological restoration projects, the choice of cheaper and effective techniques control of $U$. decumbens and selection of native plants to be used in plantations.
\end{abstract}

Keywords: target-species, allelochemicals, invasive exotic grasses. 


\section{Introdução}

No Brasil, várias espécies de gramíneas de origem africana foram introduzidas acidentalmente ou para fins forrageiros, tornando-se invasoras de ecossistemas naturais, principalmente dos ambientes abertos, como campos e cerrados (Pivello 2011). Atualmente as pastagens plantadas ocupam cerca de $26 \%$ da área total do bioma Cerrado (MMA 2010).

As gramíneas africanas usadas para a formação de pastagens foram melhoradas para suportar o clima do Cerrado e o pisoteio pelo gado, e ainda para manter altas a produtividade e as capacidades reprodutiva e competiva (Barbosa et al. 2008, Pivello 2011). Algumas espécies de gramíneas africanas são consideradas invasoras agressivas, pois se espalham a partir de pastagens cultivadas ou revegetadas para áreas naturais a taxas alarmantes (Pivello 2011, Williams \& Baruch 2000), afetando diretamente as espécies herbáceas nativas por competição, podendo causar extinções locais e perda direta da biodiversidade. Muitos estudos sugerem que os efeitos negativos de gramíneas exóticas invasoras também se estendem à regeneração de espécies lenhosas, principalmente devido ao sombreamento das plântulas de árvores e arbustos (Florentine \& Westbrooke 2004, Holl 2002). As gramíneas africanas são um exemplo de espécies engenheiras (Haemig 2011), que impactam o ecossistema como um todo, descaracterizam as fisionomias e modificam a estrutura e o regime de queima das áreas invadidadas, facilitando com isso sua própria manutenção no ambiente (Baruch et al. 1985, Coutinho 1982, D’Antonio \& Vitousek 1992, Freitas 1999).

O controle de espécies invasoras mais eficiente é o manejo e a restauração da vegetação e dos processos ecológicos, para que o ecossistema se torne mais resistente às invasões, através do restabelecimento da vegetação e dos processos ecossistêmicos 
(Drenovsky 2012). Neste sentido, a prática da restauração ecológica, que visa a reconstituição do ambiente degradado a um estado mais próximo do original, é uma das formas de alcançar este objetivo (Morin 1999). Para isso, o controle mecânico das gramíneas exóticas seguido do plantio misto de sementes de espécies nativas, incluindo diversidade de formas de vida e espécies de rápido crescimento e reprodução, podem em poucos anos controlar a ocorrência das gramíneas exóticas invasoras, especialmente em áreas campestres e savânicas, caracterizadas pela coexistência de gramíneas, arbustos e árvores, como o caso de grandes áreas do Cerrado (Sampaio et al. 2015).

Um dos requisitos importantes para o sucesso de projetos de restauração ecológica é a escolha das espécies que serão usadas nos plantios. Alguns estudos pontuam que certas características funcionais podem ser a chave para a seleção de espécies mais eficientes no restabelecimento vegetal, como por exemplo, certas árvores que rapidamente produzem sombra e competem com espécies exóticas intolerantes ao sombreamento (Jones et al. 2004, Joo Kim et al. 2008) ou árvores que afetam o crescimento de plantas de sub-bosque através de seus efeitos sobre a disponibilidade de nutrientes e pH do solo (Pearson e Vitousek 2001). Entre as características funcionais, uma das menos exploradas é a possibilidade de que algumas espécies de plantas que produzem aleloquímicos possam inibir a germinação ou crescimento de outras plantas (Cummings et al. 2012). No entanto, Srikanth \& Pushpalatha (1991) já pontuavam em seu trabalho realizado na Índia, que a produção de aleloquímicos ou a alelopatia em plantas nativas pode ser uma das características úteis na seleção de espécies a serem usadas em projetos de restauração ecológica.

A alelopatia é um fenômeno natural e tem sido reconhecida como um importante mecanismo ecológico que influencia a dominância vegetal, a sucessão, a formação de comunidades vegetais e a vegetação clímax (Carvalho 1993, Chou 1999, Ferreira 2004). 
Muitos trabalhos com alelopatia já vêm sendo realizados com espécies exóticas invasoras em diversos ambientes, buscando compreender o sucesso de estabelecimento e rápido domínio da paisagem por estas espécies (Barbosa et al. 2008, Callaway \& Aschehoug 2000, Callaway \& Ridenour 2004, Del Fabbro et al. 2014). A hipótese "novel weapons" (novas armas) sugere que alelopatia pode ser um mecanismo relacionado ao sucesso da invasão biológica, no qual uma espécie introduzida potencialmente produz efeitos alelopáticos sobre espécies de plantas vizinhas em um novo ambiente, mesmo não mostrando efeitos similares sobre as espécies vizinhas em seu local de origem, onde as plantas compartilham sua história evolutiva (Callaway \& Ridenour, 2004).

Um processo similar ao sugerido pelo conceito de novas armas também pode operar em plantas nativas, quando há um aumento da resistência das comunidades nativas à invasão. A hipótese "homeland security" (segurança ou defesa de território) proposta por Cummings et al. (2012) estabelece que plantas introduzidas podem ser particularmente susceptíveis a aleloquímicos produzidos por plantas nativas locais, já que as espécies não possuem uma experiência evolutiva juntas, o que pode dificultar a invasão.

Tanto o conceito de novas armas quanto a hipótese de defesa de território, estão baseados no fato de que a experiência evolutiva das plantas-alvo é um dos principais fatores que influenciam a sua susceptibilidade aos aleloquímicos produzidos por outras plantas (Calaway \& Ridenour 2005, Cummings et al. 2012). No entanto, para que os estudos de alelopatia realizados com espécies exóticas e nativas sejam melhor interpretados, é necessário considerar outros fatores, também importantes, na suceptibilidade das plantas-alvo aos compostos alelopáticos da planta doadora, como 
por exemplo a forma de vida, a função ecológica e as características morfofisiológicas das plantas (Meiners et al. 2012).

Em áreas de plantio de restauração ecológica no Cerrado do Distrito Federal (DF) e de Goiás (GO), Brasil, foi observado que a espécie nativa Lepidaploa aurea (Asteraceae) possui bom desempenho no estabelecimento e na cobertura do solo, demonstrado, portanto, qualidades evidentes de uma boa espécie a ser utilizada em projetos de restauração ecológica (Sampaio et al. 2015). Adicionalmente, em áreas de domínio da espécie, frequentemente são observadas zonas sem a ocorrência de algumas outras plantas, entre elas, as gramíneas exóticas invasoras Andropogon gayanus e Urochloa decumbens. Nestas áreas, é comum a presença de plântulas de espécies arbóreas usadas nos plantios de restauração, como a Acacia polyphylla e a Copaifera langsdorffii. Estas observações deram base à realização de testes laboratoriais preliminares com espécies-modelo dicotiledôneas e uma monocotiledônea (cultivares comumente usados em testes de alelopatia, como alface, rabanete, tomate e sorgo), nos quais foram demonstrados efeitos fitotóxicas em extratos vegetais $L$. aurea.

A existência de fitotoxicidade em $L$. aurea é um indício de potencial atividade alelopática em condições naturais. No entanto, antes de qualquer afirmação, é preciso considerar que muitas vezes a presença de aleloquímicos em plantas e mesmo sua ação fitotóxica em condições de laboratório não refletem atividades alelopáticas em condições naturais, isso porque o efeito alelopático das substâncias após liberação no solo é, geralmente, muito menor do que o observado em laboratório (Inderjit \& Nilsen 2003).

Ao contrário do ambiente controlado do laboratório, no ambiente natural, existem diversos outros fatores que influenciam as interações planta-planta, como por exemplo: as condições ambientais, especialmente temperatura, umidade e intensidade 
de luz, assim como as características edáficas do local e a competição por recursos (Almeida 1991, Ferreira 2004, Hadacek 2002, Inderjit \& Nilsen 2003, Macías et al. 2007, Reigosa et al. 2013).

Uma melhor compreensão da importância da alelopatia em condições naturais é limitada pela falta de bioensaios experimentais bem desenhados e interligados, e experimentos de campo que separem os efeitos da alelopatia de outras formas de interações (Inderjit \& Nilsen 2003, Nilsson 1994, Reigosa et al. 2013, Romeo \& Weidenhamer 1996). Uma das técnicas para se identificar a ocorrência de alelopatia no campo é a utilização de carvão ativado nos bioensaios. $\mathrm{O}$ carvão ativado tem uma alta capacidade de adsorção de compostos orgânicos, e é frequentemente usado para neutralizar aleloquímicos (Del Fabbro et al. 2014, Indejit \& Callaway 2003, Nolan et al. 2014, Prati e Bossdorf 2004). É comum em estudos de alelopatia a incorporação do carvão ativado ao solo como tratamento no qual a atividade alelopática é atenuada, servindo, portanto, para comparações com o tratamento sem a adição do carvão ativado. Geralmente, as mesmas plantas-alvo são cultivadas nos substratos com e sem carvão ativado em áreas afetadas e não afetadas pela espécie potencialmente alelopática (Inderjit \& Nilsen 2003).

Nolan et al. (2014) discutem que o carvão ativado pode ser usado para reduzir os efeitos alelopáticos de espécies exóticas invasoras sobre o desenvolvimento de espécies nativas. No entanto, além de atenuar a ação alelopática, o carvão ativado se liga às moléculas orgânicas de forma indiscriminada, o que por vezes resulta na modificação da composição da comunidade microbiana do solo e do crescimento das plantas-alvo (Del Fabbro et al. 2014, Kulmatiski 2011, Kulmatiski \& Beard 2006, Lau et al. 2008, Schertzer et al. 2009, Wurst \& Van Beersum 2009), ou seja, o carvão ativado pode ter 
um efeito maior sobre o desenvolvimento das plantas-alvo, que vai além do efeito resultante da atenuação da alelopatia. Em apoio a esta idéia, Abhilasha et al. (2008) descobriram que o carvão ativado produzia efeitos em solos naturais (sem esterilização), mas não em solos esterilizados, indicando que os efeitos do carvão ativado foram causados por interações com microorganismos do solo.

Com base no padrão de distribuição de espécies observado em áreas de plantio de L. aurea, assim como no estudo preliminar que identificou a fitotoxicidade da espécie, os objetivos do trabalho são: (a) testar o potencial alelopático de L. aurea sobre duas gramíneas exóticas invasoras: A. gayanus e $U$. decumbens e sobre três espécies nativas: duas arbóreas $-A$. polyphylla e $C$. langsdorffii e uma gramínea $-L$. chrysothrix, em condições controladas e (b) avaliar possíveis efeitos alelopáticos de $L$. aurea sobre as mesmas espécies em condições naturais e semi-naturais.

A hipótese a ser testada neste trabalho é a de que a $L$. aurea possui potencial alelopático que produz maiores efeitos inibitórios no desenvolvimento das gramíneas exóticas invasoras A. gayanus e $U$. decumbens do que no de outras espécies nativas, especialmente as arbóreas A. polyphilla e C. langsdorffii.

\section{Material e Métodos}

\section{Área de Estudo}

O estudo foi realizado na Reserva Biológica (Rebio) da Contagem, DF, em área de experimentos de restauração ecológica por meio de semeadura direta estabelecidos em 2012, em um local de pastagem abandonada dominada pelas gramíneas exóticas invasoras A. gayanus e $U$. decumbens. 


\section{Espécies estudadas}

A espécie doadora é a Lepidaploa aurea, um arbusto perene de porte reduzido da família Asteraceae, com altura média de 1,3 m, comumente encontrado em áreas de Cerrado do Brasil central (Farias et al. 2002) (fig. 1). As espécies do gênero são normalmente caracterizadas como ervas daninhas associadas a pastagens e culturas (Lorenzi 2000). A L. aurea pode ser definida como uma espécie ruderal, sendo facilmente encontrada ao longo de estradas no Cerrado.

As espécies-alvo selecionadas foram duas gramíneas exóticas invasoras comuns na área de estudo: Urochloa decumbens e Andropogon gayanus, cujas sementes foram adquiridas comercialmente, e três espécies nativas, sendo uma gramínea: Loudetiopsis chrysothrix e duas arbóreas: Copaifera langsdorffii e Acacia polyphylla, cujas sementes foram coletadas em área de cerrado próxima à Rebio da Contagem, DF. As duas gramíneas exóticas e as duas nativas arbóreas foram selecionadas a partir das observações de campo das zonas de inibição de crescimento no entorno de L. aurea, onde há pouca ocorrência de A. gayanus e U. decumbens e a presença de plântulas de $A$. polyphylla e $C$. langsdorffii. Não é comum observar a ocorrência da gramínea nativa $L$. chrysothrix nestas zonas de inibição, no entanto, a espécie foi selecionada como uma das espécies-alvo, por ser uma monocotiledônea, possuindo, portanto, semelhanças funcionais e fisiológicas com as gramíneas exóticas testadas, o que possibilita interpretações mais corretas da importância do histórico evolutivo e das características das espécies-alvo no padrão de distribuição de espécies existente no local de estudo. 


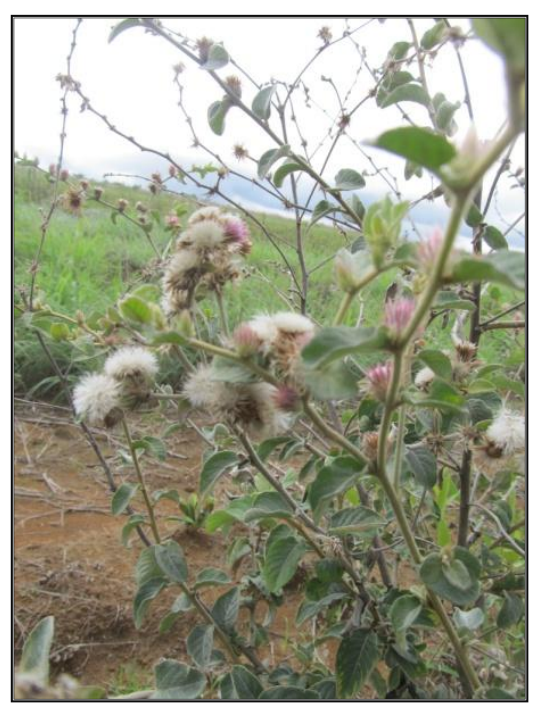

Figura 1- Indivíduo de Lepidaploa aurea em área de campo na Reserva Biológica (Rebio) da Contagem (DF).

\section{Material vegetal}

Folhas e raizes de L. aurea foram coletadas em áreas de cerrado no Distrito Federal. Para obtenção dos extratos, o material vegetal foi separado, eliminado o excesso de solo (no caso das raizes) e secado em estufa a $60^{\circ} \mathrm{C}$ por 48 horas (Costa $\&$ Pasin 2015). Depois de seco, o material foi triturado em Moinho de Rotor Tipo Ciclone. O pó resultante foi diluído em água destilada na proporção de $10 \mathrm{~g}$ de pó para cada $100 \mathrm{~mL}$ de água destilada e submetido a banho de ultrasson em Lavadora UltraSônica Digital por 25 minutos. Em seguida, a solução foi coada com o auxílio de um funil de porcelana, papel-filtro de gramatura $80 \mathrm{~g} / \mathrm{m}^{2}$ e uma bomba de vácuo. O resultado foi um extrato a $10 \%$ que foi sendo diluído em água destilada para alcançar as concentrações de $5 \% ; 2,5 \%$ e 1,25\%. O tratamento controle foi feito com água destilada. 


\section{Experimentos em laboratório}

Os bioensaios em laboratório tiveram a finalidade de avaliar o crescimento inicial das espécies-alvo, utilizando extratos aquosos de folhas e de raizes de L. aurea. Optou-se por não avaliar a germinação das espécies-alvo nos testes laboratoriais, por ter se mostrado um parâmetro pouco sensível aos extratos aquosos da $L$. aurea em testes preliminares de fitotoxicidade com a utilização de espécies-modelo (Capítulo 1). O substrato utilizado nos bioensaios em condições controladas foi a vermiculita expandida de textura fina, a qual foi disposta em sementeiras com 36 células (cada célula com capacidade de $5 \mathrm{~g}$ de substrato) e estas em bandejas plásticas (fig. 2). Em cada célula foi adicionado uma única vez o volume de extrato correspondente a $100 \%$ da capacidade de campo da vermiculita (previamente determinada). As sementes das espécies-alvo foram pré-germinadas em papel-filtro e após um período de 4 a 10 dias (dependendo da espécie) de crescimento em câmara de germinação a $25^{\circ} \mathrm{C}$ e fotoperíodo de $12 \mathrm{~h}$, foram transplantadas para as sementeiras, uma plântula por célula. Os bioensaios de cada extrato tiveram cinco tratamentos, com quatro concentrações de extrato $(10,00 ; 5,00$; 2,50 e $1,25 \%$ ) e um tratamento controle com água destilada. Para cada extrato, foi utilizada uma sementeira por tratamento $(\mathrm{N}=36)$, cinco por espécie, perfazendo um total de 180 sementes/espécie transplantadas (fig. 2). Os experimentos foram mantidos em câmara de crescimento a $25^{\circ} \mathrm{C}$ e fotoperíodo de 12 horas por 13 dias para as gramíneas e por 18 dias para as espécies arbóreas. Foi mantida em 100\% a capacidade de campo da vermiculita nos recipientes com regas diárias, as quais foram realizadas colocando-se a água no fundo das bandejas, para evitar a perda excessiva dos extratos por lixiviação. 
O crescimento inicial das espécies-alvo foi determinado por meio de medidas com paquímetro digital, dos comprimentos das partes aéreas e radiculares de cada indivíduo plantado.
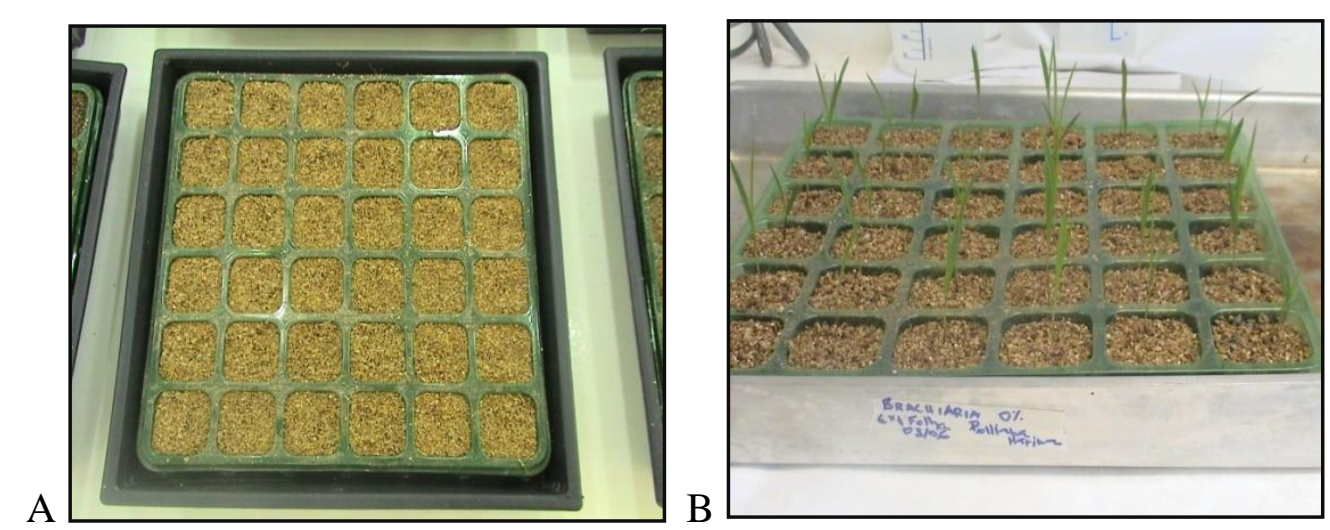

Figura 2- (A) Sementeira de 36 células com vermiculita no interior de bandeja plástica utilizada nos bioensaios laboratoriais e (B) Sementeira com plântulas de Urochloa decumbens cultivadas em vermiculita com extrato foliar de Lepidaploa aurea (tratamento controle - 0\% de extrato) em laboratório.

\section{Experimentos em casa de vegetação}

Foram realizados dois tipos de experimentos em casa de vegetação. O primeiro teve a finalidade de avaliar os efeitos alelopáticos das raizes de $L$. aurea, através da medição do comprimento das espécies-alvo após cultivo em solo em que a espécie doadora havia crescido previamente em condições semi-naturais, e o segundo, teve o objetivo de avaliar os efeitos dos aleloquímicos foliares de L. aurea, através da mensuração do comprimento e da biomassa seca das espécies-alvo cultivadas em solo coberto com folhas secas da espécie doadora, em condições semi-naturais, simulando a ação da serrapilheira em campo.

Experimento para avaliação dos aleloquímicos radiculares de L. aurea - Neste experimento foi avaliado o crescimento inicial das espécies-alvo, após o plantio em solo no qual a $L$. aurea foi previamente cultivada. 
Para o cultivo da L. aurea em condições semi-naturais, foram preenchidos dez vasos de 2,5 L com latossolo vermelho-amarelo peneirado, e em cada vaso foram plantadas dez sementes pré-germinadas de L. aurea. O procedimento de pré-germinação foi o mesmo realizado nos experimentos laboratoriais. Após o período de um mês, quatro plântulas de cada vaso foram retiradas. Os vasos com as seis plântulas restantes foram mantidos por seis meses em casa de vegetação com irrigação diária (fig. 3). Para maior contato com o sol, após esse período, os vasos foram transportados para uma área externa protegida com sombrite, dispostos em bandejas plásticas e mantidos por mais três meses com irrigação manual, de baixo para cima, de dois em dois dias. Após o período de 9 meses, as plantas foram retiradas dos vasos e o solo foi homogeneizado e dividido em duas partes. Para a atenuação dos efeitos alelopáticos da planta doadora e visando as comparações necessárias para a interpretação dos resultados, em uma das duas partes do solo foi acrescentado carvão ativado a uma concentração de $25 \mathrm{~mL}$ de carvão para $1 \mathrm{~L}$ de solo (Del Fabbro et al. 2014). O bioensaio teve, portanto, dois tratamentos, um de solo com carvão ativado e outro de solo sem carvão ativado. Os solos com e sem carvão ativado foram distribuídos cada qual em cinco sementeiras de 36 células (cada uma com capacidade de $40 \mathrm{~g}$ de substrato) e estas em bandejas plásticas. Em cada sementeira foram plantadas sementes pré-germinadas das espéciesalvo: U. decumbens, A. gayanus e L. chrysothrix, C. langsdorffii e A. polyphylla, uma plântula por célula (fig. 3). As espécies-alvo gramíneas, tanto as exóticas quanto a nativa, tiveram repetição de 36 sementes por tratamento, e as arbóreas, repetição de 30 sementes/tratamento.

As espécies-alvo plantadas nos tratamentos com e sem carvão ativado foram mantidas em câmara de crescimento a $25^{\circ} \mathrm{C}$ e fotoperíodo de 12 horas por 13 dias para 
as gramíneas e 18 dias para as espécies arbóreas. Foi mantida em 100\% a capacidade de campo do solo nos recipientes com regas diárias, as quais foram realizadas colocando-se a água no fundo das bandejas.

O crescimento inicial das espécies-alvo foi avaliado através de medições dos comprimentos das partes aéreas e das raizes de cada planta-alvo, utilizando um paquímetro digital.

A
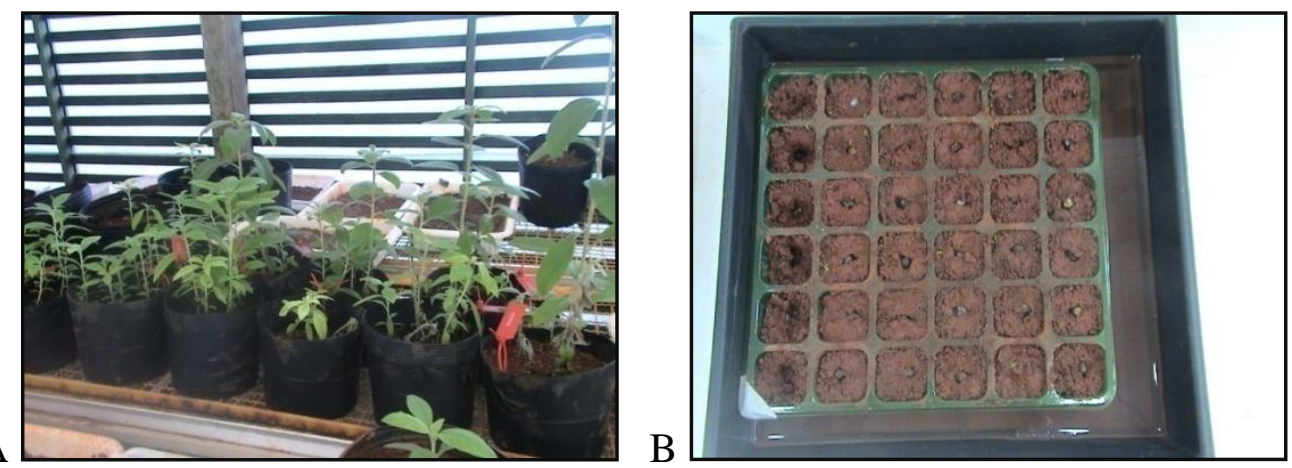

Figura 3- (A) Vasos com Lepidaploa aurea (6 indivíduos por vaso) em casa de vegetação após seis meses do plantio e (B) Sementeira com 30 sementes (pré-germinadas) de Copaifera langsdorffii dispostas em solo no qual $L$. aurea foi previamente cultivada em casa de vegetação (tratamento sem carvão ativado).

Experimento para avaliação dos aleloquímicos foliares de L. aurea - Neste experimento foi avaliado o crescimento inicial das espécies-alvo, através da medição dos seus comprimentos aéreos e radiculares e da mensuração da biomassa seca aérea e radicular de cada planta-alvo, após cultivo em latossolo vermelho-amarelo coberto com folhas secas de L. aurea, pelo período de 76 dias.

Para a implantação do experimento, noventa vasos com capacidade de $2,5 \mathrm{~L}$ e área de superfície de diâmetro de $15 \mathrm{~cm}$, foram preenchidos com uma mistura de latossolo vermelho-amarelo peneirado e areia fina, na concentração de $1 \mathrm{~kg}$ de areia para $15 \mathrm{~kg}$ de solo (Oliveira et al. 2012). Na superfície de um terço dos vasos foram dispostas folhas secas de L. aurea, em quantidade compatível com a da serrapilheira em 
campo, a qual foi previamente estimada. Os outros dois terços dos vasos foram utilizados para dois tipos de controle diferentes: um controle sem sombreamento (solo exposto) e um controle com sombreamento, no qual foi usado um sombrite para simular a redução da luminosidade proveniente da presença da serrapilheira.

Para estimar a quantidade da serrapilheira de L. aurea produzida em campo foram coletadas 20 amostras de serrapilheira em áreas dominadas pela planta. As coletas foram feitas em quadrados de 15 x $15 \mathrm{~cm}$ (área similar à superfície dos vasos usados na casa de vegetação). A serrapilheira coletada foi seca em estufa $\left(60^{\circ} \mathrm{C}\right.$ por 48h) e pesada. A média de serrapilheira nestas amostras $(4,3 \mathrm{~g})$ foi a quantidade utilizada nos vasos no experimento para avaliação dos efeitos dos aleloquímicos foliares de L. aurea.

Para medir o sombreamento causado pela serrapilheira, 4,3 g do material foram dispostos em papel-filme transparente, conforme área da superfície do vaso, e por baixo do papel-filme utilizou-se um fotômetro digital para medir a luminosidade com e sem a serrapilheira. O procedimento foi repetido vinte vezes e constatou-se que a média da porcentagem de luminosidade que a serrapilheira deixou passar foi de $30 \%$. Posteriormente os trinta vasos do controle de luminosidade foram cobertos com sombrite de gramatura de $70 \%$ de sombreamento. O sombrite foi mantido sobre os vasos no controle com sombreamento até que as plantas do tratamento com a serrapilheira ultrapassassem a barreira das folhas secas.

$\mathrm{Na}$ metade dos vasos de cada tratamento foram plantadas sementes prégerminadas de $U$. decumbens e na outra metade, de L. chrysothrix, perfazendo um número de repetições de 15 para cada espécie-alvo por tratamento. Inicialmente foram 
plantadas quatro sementes pré-germinadas por vaso e após uma semana, três delas foram retiradas e foi mantida apenas uma planta por vaso. As plantas foram cultivadas em casa de vegetação e regadas periodicamente para manutenção de $100 \%$ da capacidade de campo dos vasos, pelo período de 76 dias. As regas foram feitas de cima para baixo, para a liberação no solo dos compostos existentes na serrapilheira. Para a quantificação do crescimento inicial, após o desmonte do bioensaio, foi medido o comprimento e mensurada a biomassa seca das partes aéreas e radiculares de cada planta-alvo.

\section{Experimento em campo}

O bioensaio in situ teve a finalidade de avaliar a germinação e o crescimento inicial das espécies-alvo em condições naturais, através do plantio de sementes das plantas-alvo em áreas afetadas e não afetadas pela $L$. aurea, em parcelas com e sem carvão ativado. Para isso, em novembro de 2014, foram selecionadas dez manchas de $L$. aurea (áreas dominadas pelo arbusto) em áreas de plantios de restauração ecológica realizados em 2012, na Reserva Biológica da Contagem, DF. Em cada uma dessas manchas foram plantadas as espécies-alvo: $U$. decumbens, A. gayanus, L. chrysothris, A. polyphylla e C. langsdorffii em parcelas de 20 x $20 \mathrm{~cm}$. As parcelas foram demarcadas em dois tipos de tratamento: dentro da mancha (cerca de $20 \mathrm{~cm}$ de uma planta de $L$. aurea) e fora da mancha (mínimo de $3 \mathrm{~m}$ de distância de um indivíduo de L. aurea). Em cada tratamento foram feitas duas parcelas $(20 \times 20 \mathrm{~cm})$ para cada espécie-alvo, em uma delas, foi incorporado o carvão ativado em aproximadamente $2 \mathrm{~kg}$ de solo, na proporção de $25 \mathrm{~mL}$ de carvão para $1 \mathrm{~L}$ de solo (Del Fabbro et al. 2014). Para a incorporação do carvão ativado ao solo, os $2 \mathrm{~kg}$ de solo foram retirados da parcela e o carvão ativado foi acrescentado ao substrato, revolvendo-se a mistura. Sendo 
assim, cada espécie-alvo foi plantada em quatro parcelas por mancha: com carvão dentro, sem carvão - dentro, com carvão - fora, sem carvão - fora e cada mancha representou uma repetição. Para eliminar o efeito da perturbação decorrente da adição do carvão ativado ao solo, nas parcelas sem o carvão ativado, antes do plantio, o solo foi revolvido da mesma maneira que nas parcelas nas quais foi misturado o carvão. Em cada mancha foram demarcadas duas parcelas nas quais não foi plantada nenhuma espécie-alvo (uma dentro e uma fora da mancha), para excluir o efeito do surgimento de espécies espontâneas. Nestas parcelas de controle de espontâneas, o solo foi revolvido da mesma maneira que nas outras parcelas com e sem carvão ativado (fig. 4).

Em cada parcela foram plantadas 40 sementes de cada espécie-alvo, com exceção da espécie L. chrysothrix, para a qual foram plantadas 100 sementes por parcela. Optou-se por plantar um número maior de sementes de L. chrysothrix por que foi constatado, em experimentos anteriores, que esta espécie apresenta baixo percentual de germinação de sementes. Após o plantio, foram realizados cinco monitoramentos da germinação, semanalmente durante o primeiro mês e ao final do segundo mês. No final do segundo mês reduziu-se o número de plantas por parcelas para no máximo de 20 , para evitar efeitos decorrentes da densidade. O experimento foi desmontado após seis meses de crescimento e as plantas remanescentes foram retiradas das parcelas com o auxílio de ferramentas de jardinagem, acondicionadas em sacos plásticos identificados e levadas a laboratório para avaliação do crescimento inicial, através da realização das medições do comprimento e a quantificação da biomassa seca das partes aéreas e raizes de cada planta-alvo. 


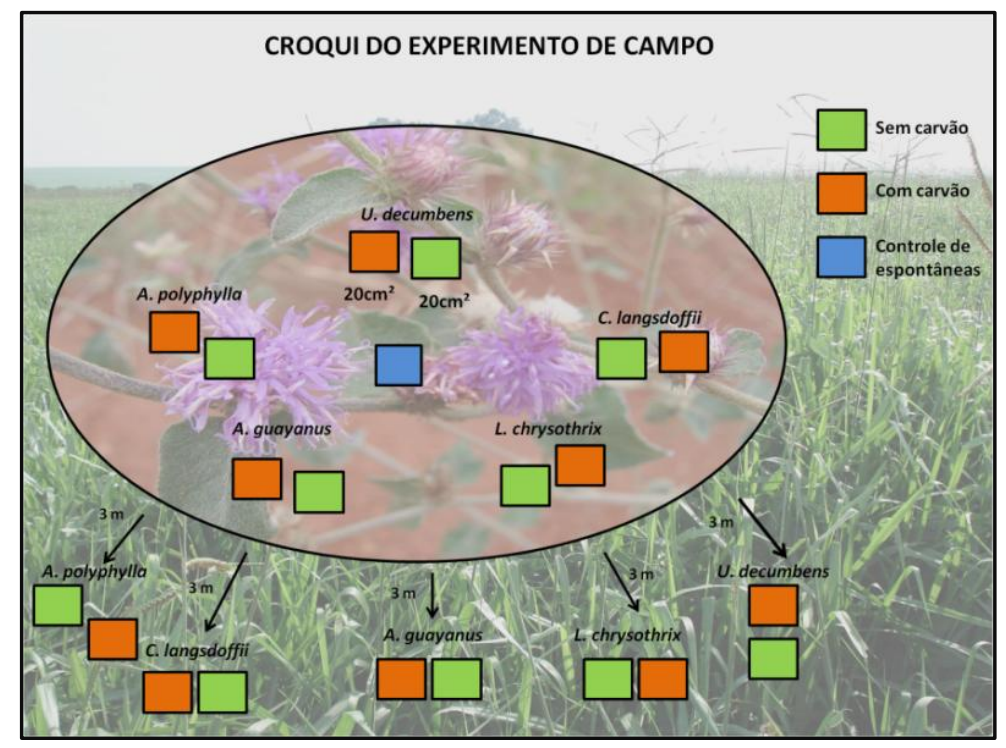

Figura 4- Croqui do experimento em campo. Disposição das parcelas em uma mancha de Lepidaploa aurea (áreas dominadas pela espécie). As cinco espécies-alvo: Andropogon gayanus, Urochloa decumbens, Loudetiopsis chrysothrix, Copaifera langsdorffii e Acacia polyphylla, foram plantadas em duas condições (com e sem carvão ativado no solo) em parcelas de 20 x $20 \mathrm{~cm}$ localizadas dentro de áreas dominadas por Lepidaploa aurea (no círculo) e fora de áreas dominadas por esta espécie potencialmente alelopática, a no mínimo 3 metros de distância de um indivíduo de Lepidaploa aurea. Também foram demarcadas parcelas de controle de espontâneas dentro e fora das manchas de Lepidaploa aurea, para evitar erros na contagem de indivíduos, caso ocorresse o surgimento espontâneo de espécies que não foram plantadas.

\section{Análises Estatísticas}

Os resultados dos bioensaios para avaliar o crescimento inicial das espécies-alvo realizados em laboratório e em casa de vegetação foram avaliados por meio de Análises de Variância (ANOVA), considerando os tratamentos para cada espécie. Para os resultados de germinação e crescimento inicial das espécies-alvo cultivadas em campo, foram realizadas ANOVA de dois fatores: local (dentro e fora das manchas de L. aurea) e presença de carvão ativado na parcela (com ou sem) para cada espécie separadamente. As médias foram comparadas pelo teste de Tukey a 5\% de significância. As análises foram realizadas no Programa R, versão 3.2.1 (R Development Core Team 2015). 


\section{Resultados}

\section{Experimentos laboratoriais}

Nos testes para avaliação do crescimento inicial realizados em laboratório, o extrato foliar de L. aurea provocou forte efeito sobre as plantas-alvo, reduzindo significativamente os crescimentos das partes aéreas e radiculares de todas elas, com exceção da parte aérea de $C$. langsdorffii. A espécie mais afetada pelo extrato foliar foi a $U$. decumbens (parte aérea: $\mathrm{F}_{4,175}=7,2 ; \mathrm{p}<0,0001 ; \mathrm{N}=36$ e parte radicular $=\mathrm{F}_{4,175}=$ 156; $\mathrm{p}<0,0001 ; \mathrm{N}=36$ ), que mostrou redução da radícula a partir da concentração de extrato de $1,25 \%$ (fig. 6 ). Já o extrato de raiz de $L$. aurea teve pouca influência sobre o crescimento inicial das espécies-alvo, afetando apenas o crescimento radicular de duas espécies: $U$. decumbens $\left(\mathrm{F}_{4,175}=5,9 ; \mathrm{p}<0,0001 ; \mathrm{N}=36\right)$, que apresentou redução da radícula conforme o aumento da concentração do extrato (fig. 6) e C. langsdorffii $\left(\mathrm{F}_{4}\right.$, $\left.{ }_{175}=3,5 ; \mathrm{p}=0,0085 ; \mathrm{N}=30\right)$, que apresentou aumento da radícula proporcional ao aumento da concentração do extrato (figs. 5, 6 e 7).
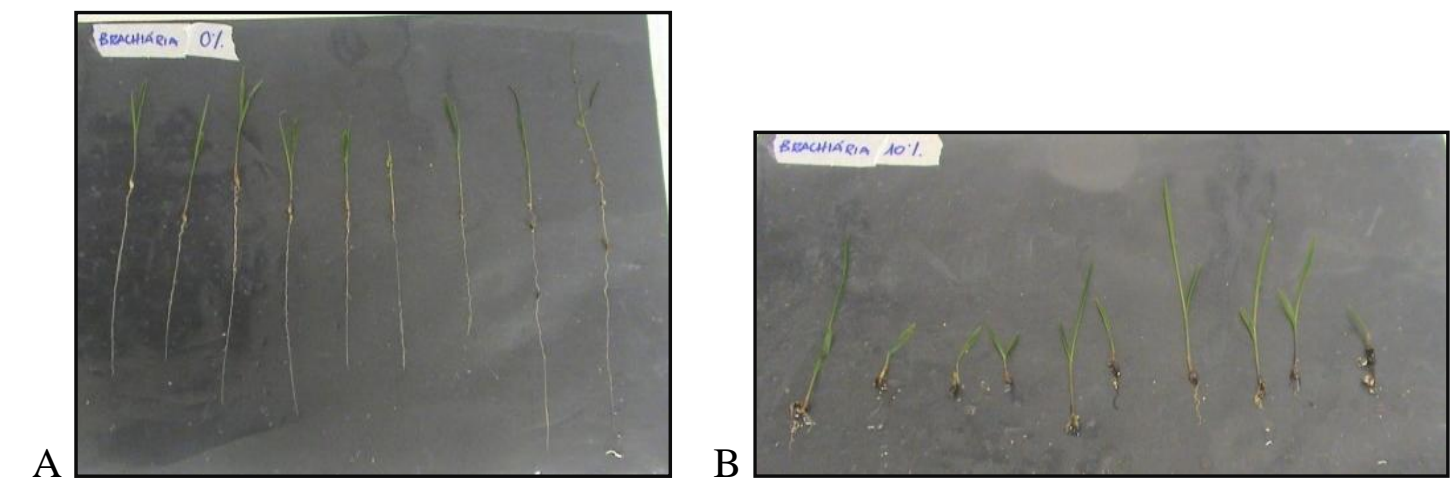

Figura 5- Urochloa decumbens após cultivo em vermiculita em laboratório: (A) com extrato de folha de Lepidaploa aurea na concentração $0 \%$ (controle), (B) com extrato de folha de L. aurea na concentração $10 \%$. 


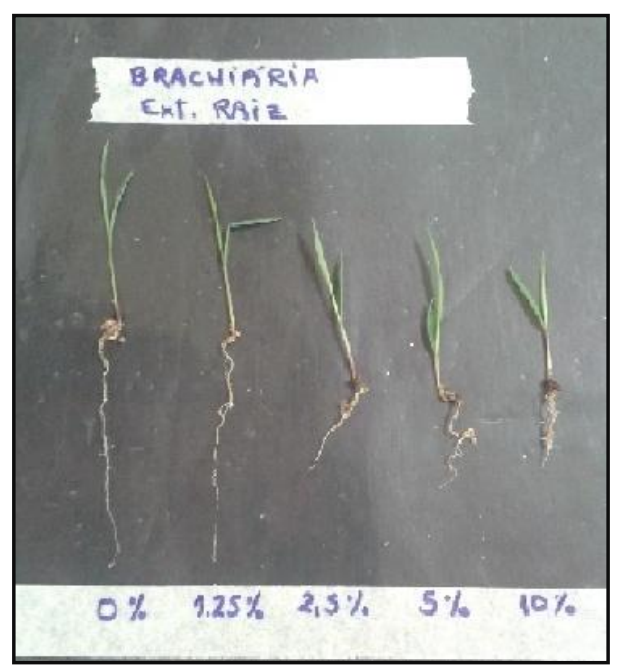

Figura 6- Urochloa decumbens cultivada em laboratório em vermiculita com extrato de raiz de $L$. aurea nas concentrações de $0 \%$ (controle), 1,25\%,2,50\%, 5,00\% e 10,00\%, respectivamente da esquerda para a direita.
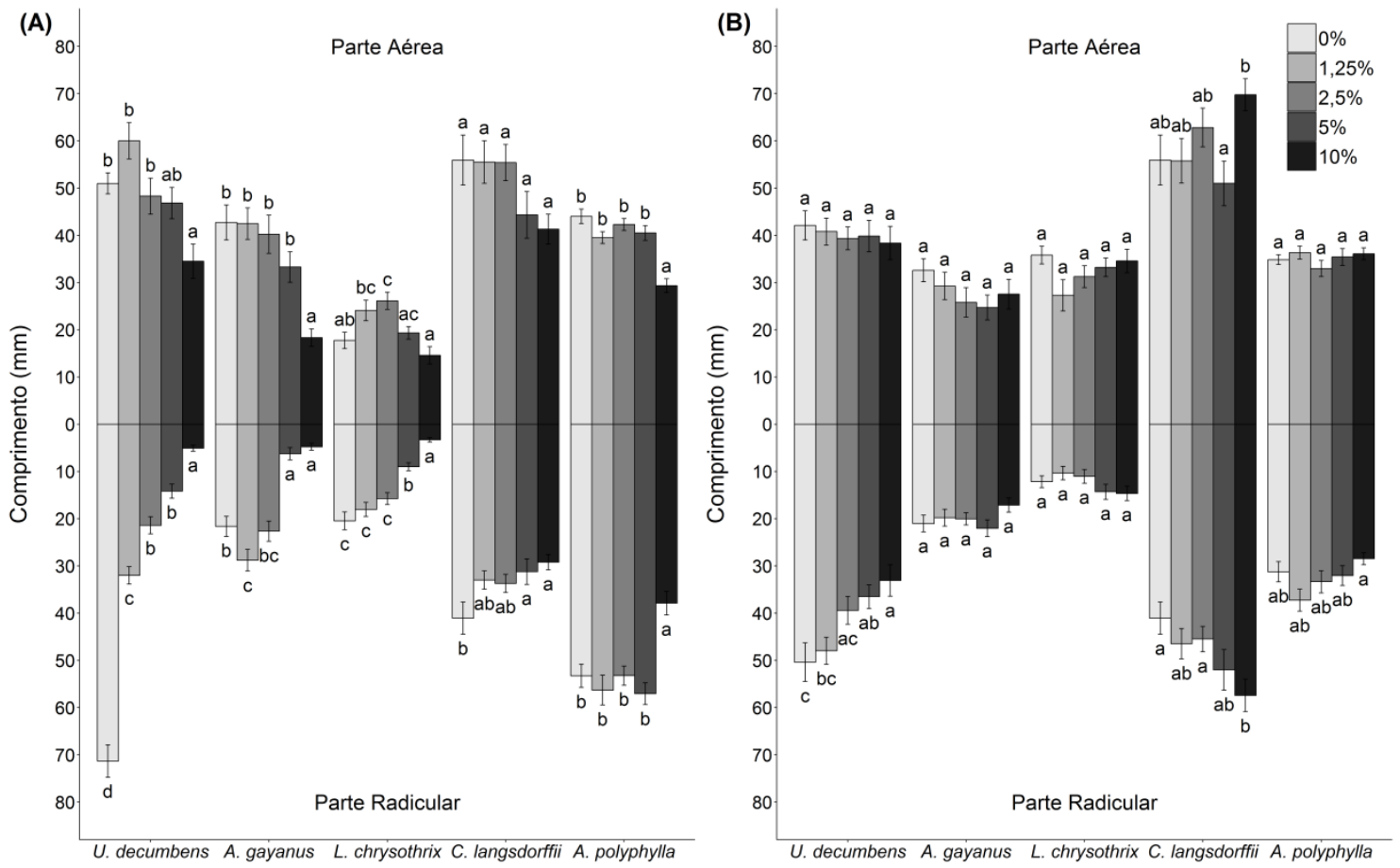

Figura 7- Comprimento das espécies-alvo cultivadas em vermiculita em laboratório pelo período de 13 dias para as gramíneas e de 18 dias para as espécies arbóreas: (A) com extrato de folha de Lepidaploa aurea e (B) com extrato de raiz de Lepidaploa aurea. As barras representam as médias dos comprimentos das espécies-alvo para cada tratamento (concentrações dos extratos). Diferentes letras representam as diferenças entre os tratamentos. As análises foram feitas para cada espécie separadamente e letras iguais sobre diferentes espécies não indicam resultados iguais. 


\section{Experimentos em Casa de Vegetação}

No experimento para avaliação do crescimento inicial das espécies-alvo cultivadas em solo no qual a $L$. aurea foi previamente plantada, os compostos alelopáticos liberados pelas raizes de $L$. aurea possivelmente afetaram significativamente o crescimento inicial de três das cinco espécies-alvo. Tais substâncias aparentemente inibiram o crescimento aéreo e radicular da espécie $A$. polyphylla (parte aérea: $\mathrm{F}_{1,58}=17,59 ; \mathrm{p}<0,0001 ; \mathrm{N}=30$ e parte radicular: $\mathrm{F}_{1,58}=5,843$; $\mathrm{p}=0,0188 ; \mathrm{N}=30$ ), pois a espécie apresentou crescimento reduzido em solo sem carvão ativado, se comparado ao tratamento com carvão ativado. Padrão semelhante foi observado para o crescimento radicular de $U$. decumbens $\left(\mathrm{F}_{1,70}=30,69 ; \mathrm{p}<0,0001 ; \mathrm{N}=\right.$ 36). Por outro lado, os aleloquímicos presentes no solo possivelmente foram responsáveis pelo aumento do crescimento da radícula de $C$. langsdorffii $\left(\mathrm{F}_{1,31}=6,173\right.$; $\mathrm{p}=0,019 ; \mathrm{N}=19)$, já que esta espécie apresentou crescimento significativamente maior no tratamento sem carvão ativado (fig. 8)

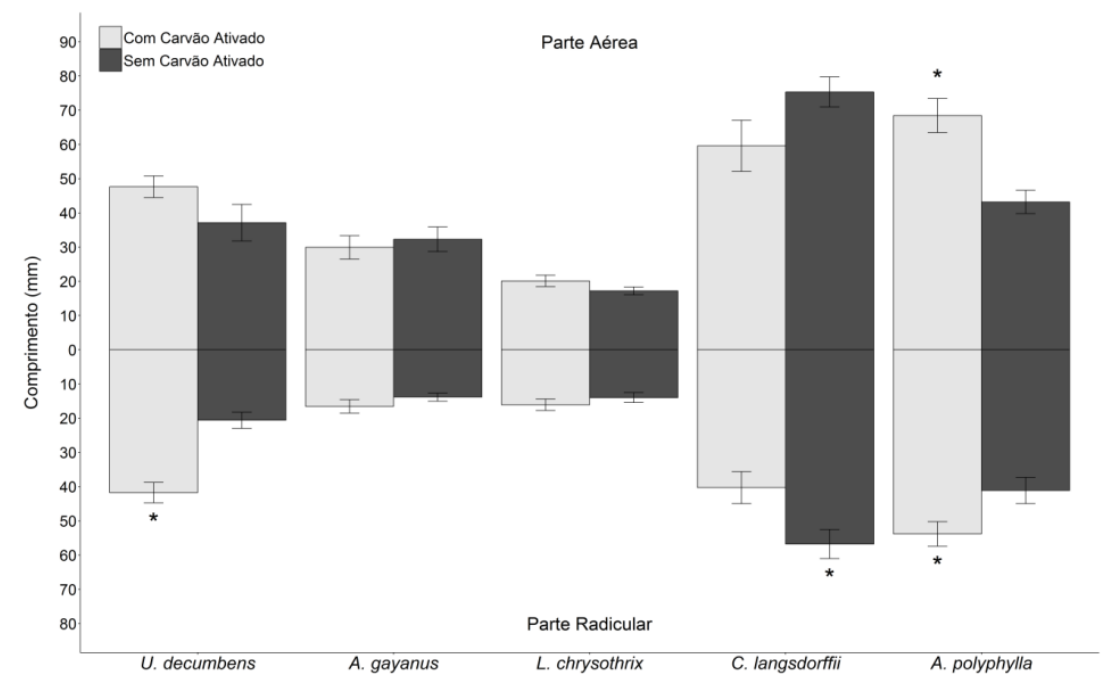

Figura 8: Comprimento das espécies-alvo cultivadas pelo período de 13 dias para as gramíneas e de 18 dias para as espécies arbóreas, em solo no qual Lepidaploa aurea cresceu durante 9 meses em casa de vegetação, com e sem carvão ativado. As barras representam a média do comprimento das espécies-alvo para cada tratamento (com e sem carvão ativado). Os asteriscos representam diferenças significativas entre os tratamentos. 
No experimento para avaliação do crescimento inicial das espécies-alvo cultivadas em solo coberto com folhas secas de L. aurea em casa de vegetação, aparentemente os aleloquímicos foliares da espécie doadora tiveram pouca influência no crescimento inicial das espécies-alvo, possivelmente afetando somente a biomassa radicular de $L$. chrysothrix (parte radicular: $\mathrm{F}_{2,40}=6,4 ; \mathrm{p}=0,004 ; \mathrm{N}=15$ ), que apresentou a média dos valores significativamente maior no tratamento com a presença das folhas secas, se comparados à média dos valores do controle sem luminosidade (solo exposto). Os comprimentos das espécies-alvo não foram influenciados neste bioensaio. Todavia, $U$. decumbens (parte radicular: $\mathrm{F}_{2,38}=4,3 ; \mathrm{p}=0,021 ; \mathrm{N}=15$ ) obteve comprimento significativamente reduzido no tratamento de controle com sombreamento se comparado ao controle sem sombreamento (fig. 9).
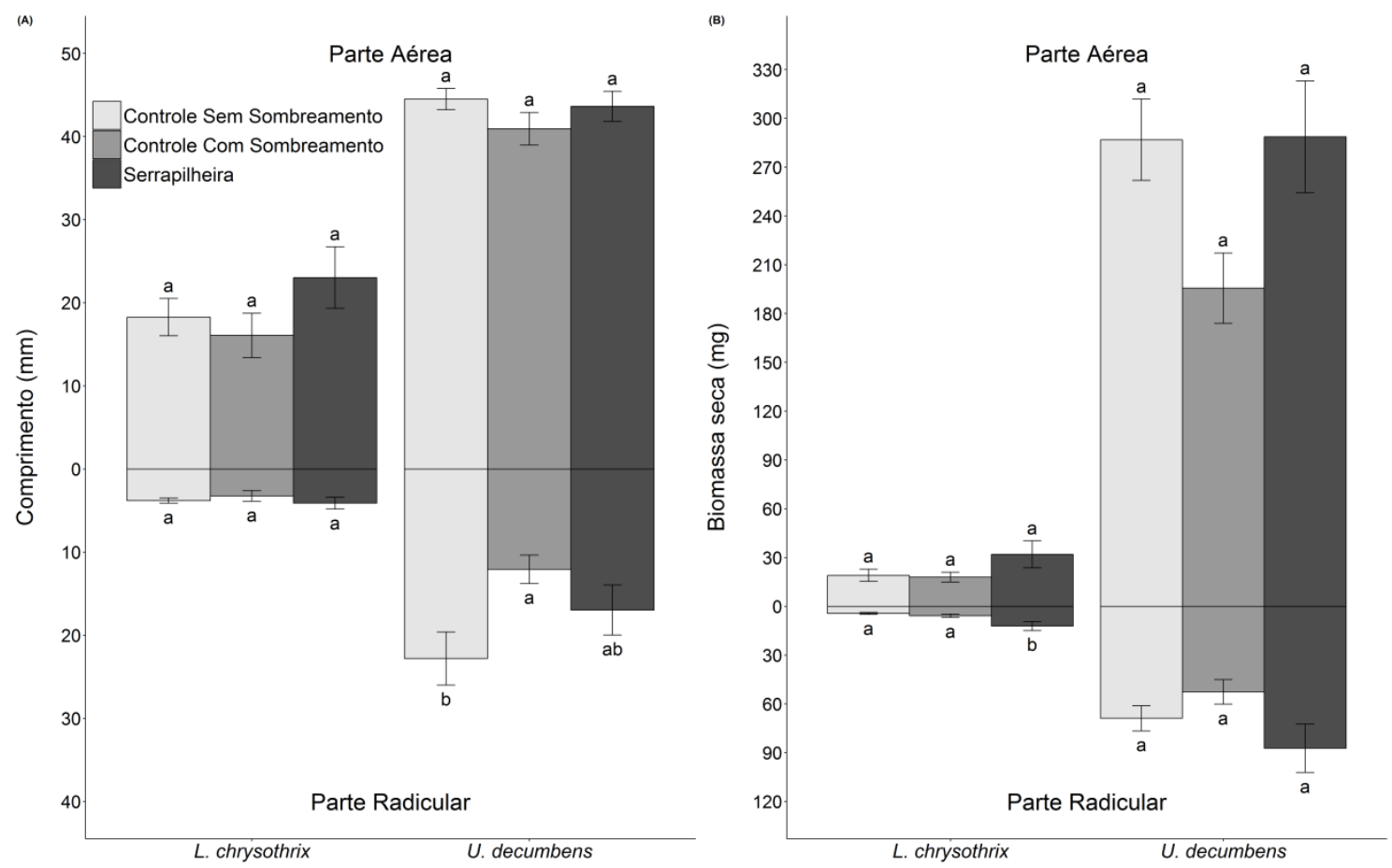

Figura 9- (A) Comprimento das espécies-alvo cultivadas por 76 dias em solo coberto com folhas secas de Lepidaploa aurea em casa de vegetação e (B) Biomassa seca das espécies-alvo cultivadas por 76 dias em solo coberto com folhas secas de $L$. aurea em casa de vegetação. As barras representam a média nos valores de comprimento e biomassa seca das espécies-alvo em cada tratamento (serrapilheira e controles com e sem sombreamento). Diferentes letras representam as diferenças entre os tratamentos. As análises foram feitas para cada espécie separadamente e letras iguais sobre diferentes espécies não indicam resultados iguais. 
No bioensaio de crescimento realizado em casa de vegetação no qual foram avaliados os efeitos dos aleloquímicos radiculares de $L$. aurea, foram observados efeitos inibitórios sobre o comprimento de $U$. decumbens, os quais não foram constatados no bioensaio com a utilização de folhas secas da espécie doadora, na mesma condição. Esse padrão de respostas foi diferente do observado nos testes de crescimento realizados em laboratório, já que em condições laboratoriais os extratos de folha de L. aurea tiveram maior influência sobre o crescimento inicial das espécies-alvo do que os extratos de raiz.

A outra espécie testada no experimento para avaliação dos aleloquímicos das folhas de L. aurea em casa de vegetação: L. chrysothrix, também apresentou comportamento diferente do observado nos testes de crescimento realizados em laboratório com o uso do extrato foliar da planta doadora. Em condições controladas, o contato com o extrato foliar de L. aurea provocou a redução do crescimento inicial de $L$. chrysothix, já em condições semi-naturais, foi observado o aumento da biomassa radicular desta espécie-alvo no tratamento de solo coberto com folhas secas, o que sugere a possibilidade de que aleloquímicos foliares de $L$. aurea tenham sido responsáveis pelo estímulo ao crescimento desta espécie, nesta condição.

\section{Experimentos em Campo}

Nos experimentos para avaliação da germinação das espécies-alvo realizado em condições naturais, foi constatado que os aleloquímicos produzidos por L. aurea aparentemente tiveram pouca influência sobre a germinação das espécies-alvo em campo, afetando somente $C$. langsdorffii $\left(\mathrm{F}_{1,34}=17,4 ; \mathrm{p}=0,0002 ; \mathrm{N}=10\right)$, que teve sua germinação estimulada, já que a espécie apresentou um número maior de sementes 
germinadas nas parcelas sem carvão ativado dentro das manchas de L. aurea, se comparado ao das parcelas com carvão ativado. Para a maioria das espécies-alvo, independente da localização da parcela (dentro ou fora das manchas), a presença do carvão ativado não alterou significativamente os valores de germinação. Todas as espécies-alvo apresentaram maiores valores de germinação dentro das manchas de $L$. aurea (fig. 10).

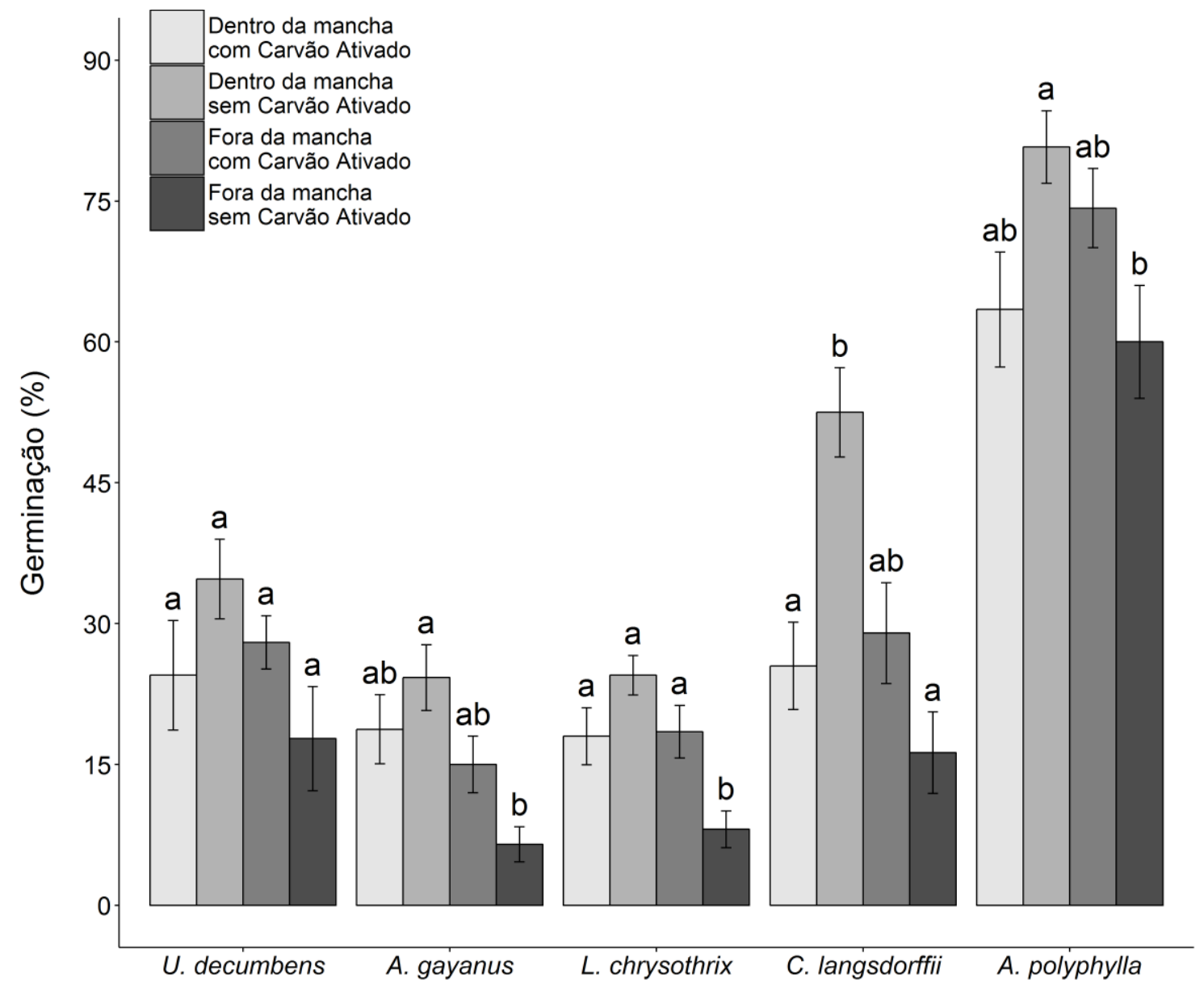

Figura 10- Percentual de germinação das espécies-alvo cultivadas em campo por 6 meses, dentro e fora de manchas de Lepidaploa aurea (áreas dominadas pela espécie) em parcelas com e sem carvão ativado. As barras representam as médias dos percentuais de germinação das espécies-alvo em cada tratamento (dentro - com carvão, dentro - sem carvão, fora - com carvão, fora - sem carvão). Diferentes letras representam as diferenças entre os tratamentos. As análises foram feitas para cada espécie separadamente e letras iguais sobre diferentes espécies não indicam resultados iguais.

Os aleloquímicos de L. aurea aparentemente não afetaram o crescimento inicial das espécies-alvo em condições de campo, já que não foram observadas diferenças nos 
comprimentos e nas biomassas secas das espécies-alvo ao se comparar as parcelas com e sem carvão ativado localizadas dentro das manchas de L. aurea. No geral, foi observado maior crescimento inicial das espécies-alvo dentro das manchas de L. aurea do que fora delas, com exceção da espécie C. langsdorffii $\left(\mathrm{F}_{3,277}=3,8 ; \mathrm{p}=0,016 ; \mathrm{N}=10\right)$ que apresentou maiores valores de biomassa seca da parte radicular nas parcelas fora das manchas, sem, no entanto, mostrar diferenças significativas nos valores observados nas parcelas com e sem carvão ativado (fig. 11). O tratamento fora da mancha com carvão ativado foi desconsiderado para a espécie A. gayanus, pois neste tratamento, a espécie apresentou um $\mathrm{N}$ muito pequeno, de apenas 3 indivíduos, o que poderia influenciar erroneamente o resultado do bioensaio.
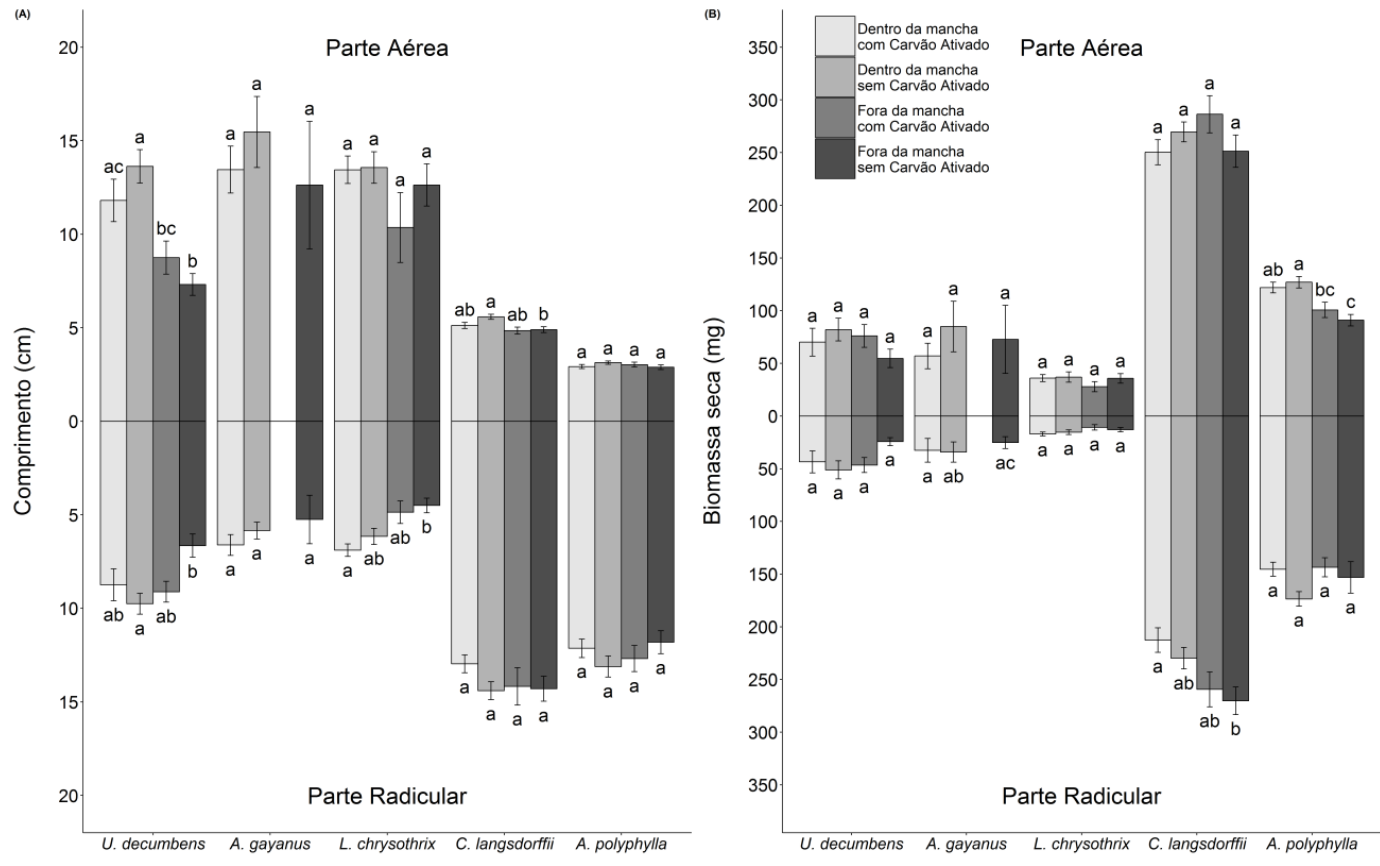

Figura 11- (A) Comprimento das espécies-alvo cultivadas em campo por 6 meses, dentro e fora de manchas de Lepidaploa aurea, em parcelas com e sem carvão ativado. (B) Biomassa seca das espéciesalvo cultivadas em campo por 6 meses, dentro e fora de manchas de L. aurea, em parcelas com e sem carvão ativado. As barras representam as médias dos valores de comprimento e de biomassa seca das espécies-alvo em cada tratamento (dentro - com carvão, dentro - sem carvão, fora - com carvão, fora sem carvão). Diferentes letras representam as diferenças entre os tratamentos. As análises foram feitas para cada espécie separadamente e letras iguais sobre diferentes espécies não indicam resultados iguais. 


\section{Discussão}

Foi observado em condições laboratoriais, que os extratos foliares de L. aurea produziram efeitos mais acentuados sobre o crescimento inicial das espécies-alvo do que os extratos de raízes, o que pode ter acontecido em decorrência do fato da planta produzir uma grande quantidade de folhas, que após liberadas no solo, formam uma camada de serrapilheira relativamente densa, de $191 \mathrm{~g} / 1 \mathrm{~m}^{2}$, que recobre o solo abaixo dos indivíduos de L. aurea durante todo o ano. Adicionalmente, a planta possui um sistema radicular relativamente pequeno, o que sugere que $L$. aurea possivelmente invista mais na produção e/ou alocação de aleloquímicos em suas folhas. Ademais, resultados similares foram obtidos em bioensaios preliminares com extratos de folhas e raizes de $L$. aurea sobre a germinação e o crescimento inicial de espécies-modelo (Capítulo 1 deste trabalho). Nestes bioensaios, também foi observado, após testes de osmolaridade, que os efeitos dos extratos foliares de L. aurea, mesmo na concentração mais alta (10\%), não foram de natureza osmótica. O mesmo padrão de respostas foi encontrado em outros trabalhos que comparam os efeitos de extratos aquosos de folhas e de raizes sobre o desenvolvimento inicial de espécies-alvo (Dorning \& Cippolini 2005, Pereira et al. 2008).

No geral, os extratos de L. aurea testados em condições laboratoriais, especialmente os foliares, provocaram a inibição do crescimento inicial das espéciesalvo. A única espécie que teve o crescimento aumentado em condições controladas foi C. Langsdorffii, que apresentou o crescimento radicular estimulado na presença do extrato de raiz de L. aurea. 
Com relação aos resultados obtidos em laboratório, é importante ter em mente que, com exceção da espécie $U$. decumbens, grande parte das outras espécies-alvo que foram afetadas pelos extratos foliares e radiculares de L. aurea em condições controladas, apresentou o crescimento reduzido somente na maior concentração dos extratos $(10 \%)$, cuja reprodução em condições naturais é pouco provável. De fato, muitos autores discutem que as concentrações de extratos vegetais utilizadas em testes laboratoriais frequentemente não correspondem à realidade encontrada no campo (Inderjit \& Nilsen 2003, Inderjit \& Callaway 2003). Ou seja, as respostas das espéciesalvo obtidas em testes laboratoriais, devem ser corroboradas por testes realizados em condições semi-naturais e naturais, para que tenham, de fato, relevância na formação do padrão de distribuição de espécies observado na área de estudo.

As diferenças nos padrões de respostas das espécies-alvo após contato com os aleleoquímicos foliares de L. aurea observadas nos bioensaios de crescimento realizados em condições laboratoriais e semi-naturais, podem ser explicadas pela ação de fatores ambientais inerentes ao experimento com a utilização das folhas secas de $L$. aurea em casa de vegetação, como por exemplo, efeitos da biota do solo ou da disponibilidade de recursos, os quais podem ter provocado modificações nos efeitos alelopáticos de L. aurea (Hadacek 2002, Macías et al. 2007, Reigosa et al. 2013) . No experimento com a utilização de folhas secas de $L$. aurea em casa de vegetação também foi observado que o comprimento da parte radicular da espécie $U$. decumbens foi reduzido no tratamento de controle de luminosidade (sombrite) em comparação ao controle sem sombreamento, o que pode ser considerado mais um indício de que fatores ambientais possivelmente tenham afetado os resultados deste experimento. Apesar de previamente estimado, o efeito da redução da luminosidade gerado pelo sombrite, talvez 
tenha sido maior do que o da serrapilheira, e possivelmente tenha se sobreposto ao efeito alelopático de $L$. aurea, fazendo com que $U$. decumbens apresentasse menor crescimento radicular.

Foi observada a redução da parte radicular de $U$. decumbens (fig. 12) e o aumento da parte radicular de $C$. langsdorffii possivelmente em decorrência da ação dos aleloquímicos produzidos pelas raizes de L. aurea, tando em laboratório quanto em casa de vegetação. A provável ocorrência de efeitos alelopáticos de L. aurea sobre $U$. decumbens e $C$. langsdorffii observados também em condições semi-naturais, aumenta a evidência de que essas espécies-alvo podem ser, de fato, susceptívies à ação dos aleloquímicos da espécie doadora. O resultado de inibição da gramínea exótica invasora - U. decumbens, em decorrência da exposição aos aleloquímicos da espécie nativa $-L$. aurea, condiz com o padrão estabelecido pela hipótese da defesa de território (homeland security), a qual sugere que espécies exóticas introduzidas em um novo ambiente potencialmente não possuem defesas ou possuem poucas defesas contra os aleloquímicos de espécies nativas do local, já que as espécies não compartilham um histórico evolutivo (Callaway \& Ridenour 2004). No entanto, antes considerar que o padrão desta hipótese esteja atuando no local de estudo, é necessário observar outros resultados obtidos neste trabalho: Primeiro; a gramínea exótica invasora A. gayanus só teve o crescimento inicial reduzido em laboratório, e não foi afetada nos bioensaios para avaliação dos efeitos dos aleloquímicos radiculares de $L$. aurea em casa de vegetação. Além disso, a espécie não foi testada no experimento de crescimento realizado com a utilização de folhas secas da espécie doadora em condições semi-naturais. Sendo assim, foi demonstrado que a atividade alelopática de L. aurea possivelmente foi responsável pela inibição do crescimento de apenas uma espécie exótica invasora, resultado pouco 
consistente para extrapolação ou generalização. Segundo; foi observado o estímulo ao crescimento radicular da gramínea nativa L. chrysothrix no experimento com o uso de folhas secas de L. aurea em condições semi-naturais, mesmo que este efeito não tenha sido observado anteriormente em laboratório.

Os diferentes comportamentos das gramíneas $U$. decumbens, A. gayanus e $L$. chrysothrix, após contato com os aleloquímicos de $L$. aurea, sugerem que possivelmente as diferenças nas características funcionais e/ou morfofisiológicas das espécies, talvez tenham tido mais importância para a susceptibilidade aos aleloquímicos de $L$. aurea do que o fato de elas serem exóticas ou nativas. Um exemplo desse entendimento é o fato da espécie exótica $U$. decumbens possuir o hábido de crescimento decumbente, que se caracteriza por um rápido crescimento inicial das plantas, as quais acabam se prostrando no solo e fechando-o por completo em pouco tempo (Macedo 2002). Característica esta, diferente da outra gramínea exótica - A. gayanus, e da gramínea nativa - L. chrysothrix, que possuem ambas o hábito de crescimento ereto, com maior investimento em crescimento vertical, o que promove às espécies um porte mais alto (Da Silva 2008). O crescimento inicial mais vigoroso de U. decumbens, possivelmente faz com que esta espécie necessite de uma maior quantidade de água na fase inicial de desenvolvimento, o que pode resultar em um maior acesso aos aleloquímicos que estão disponíveis na água presente no substrato. De fato, o rápido crescimento inicial de $U$. decumbens foi constatado em todos os bioensaios deste trabalho, pois mesmo apresentando o crescimento inicial mais inibido pelos aleloquímicos de L. aurea do que as outras duas gramíneas, ainda assim mostrou maiores comprimentos ou comprimentos similares das partes aéreas e radiculares se comparados aos das espécies A. gayanus e L. chrysothrix. Por outro lado, considerando que A. gayanus e L. chrysothrix possuem características morfofisiológicas mais 
semelhantes, em decorrência do mesmo habito de crescimento, o fato de os aleloquímicos de $L$. aurea aumentarem o crescimento inicial de $L$. chrysothrix e não produzirem efeitos sobre o crescimento de A. gayanus, talvez possa ser explicado pelo fato de a primeira espécie ser nativa e possuir, portanto, um histórico evolutivo com a $L$. aurea. Ainda assim, para que o padrão de distribuição de espécies seja explicado pela hipótese da defesa de território, devem ser realizados testes com mais espécies exóticas e nativas com semelhantes características funcionais, fisiológicas e morfológicas. O passo subsequente seria, portanto, a realização de testes para avaliação do potencial alelopático de $L$. aurea sobre gramíneas nativas que convivam na mesma área com a espécie doadora e que possuam semelhantes características morfofisiológicas e funcionais das observadas em $U$. decumbens.
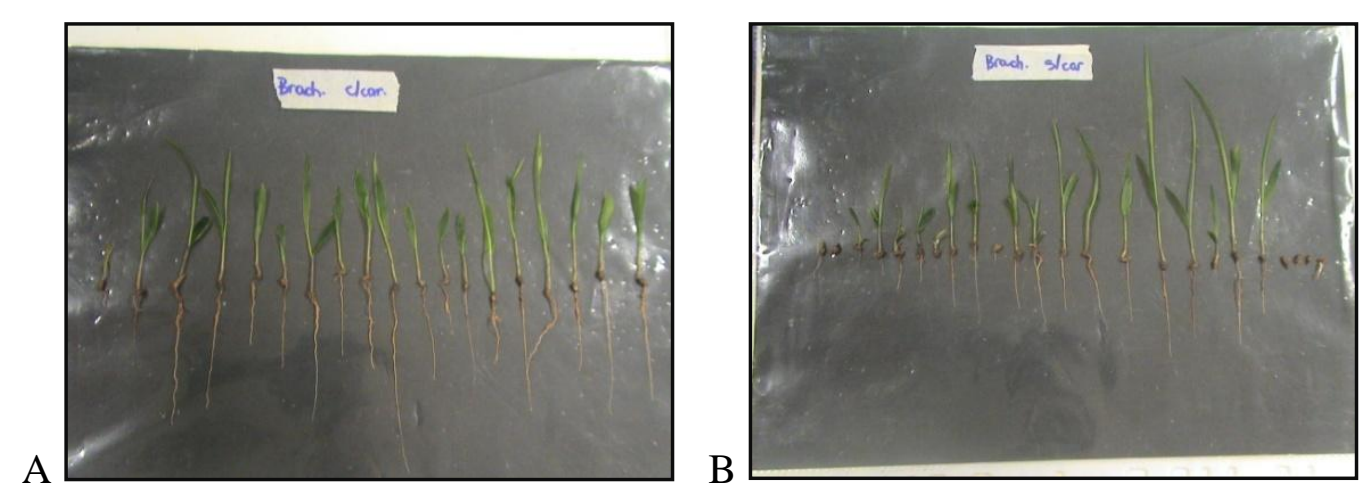

Figura 12- (A) Urochloa decumbens após plantio em solo no qual Lepidaploa aurea foi previamente cultivada em casa de vegetação (tratamento com carvão ativado) e (B) Urochloa decumbens após plantio em solo no qual Lepidaploa aurea foi previamente cultivada em casa de vegetação (tratamento sem carvão ativado).

Apesar dos aleloquímicos de L. aurea provavelmente terem beneficiado as espécies nativas $C$. langsdorffii e L. chrysothrix em condições semi-naturais, eles possivelmente também foram responsáveis pela redução do crescimento aéreo e radicular da espécie arbórea nativa A. polyphylla, demonstrando que algumas espécies nativas podem ser prejudicadas pelo contato com os compostos alelopáticos de $L$. aurea. Essa resposta negativa de A. polyphylla aos aleloquímicos de L. aurea, indica 
que possivelmente, na condição semi-natural, fatores relacionados ao solo atuaram na intensificação dos efeitos alelopáticos de L. aurea sobre esta espécie-alvo, o que pode ter sido em decorrência da ação microbiana, através da transformação dos compostos em subprodutos tóxicos (Inderjit 2005, Lankau 2009, Inderjit \& Weston 2000, Andrade et al. 2013). Esse entendimento pode ser reforçado pelo fato de que em bioensaios laboratoriais preliminares com espécies-modelo, foi demonstrado que os efeitos fitotóxicos dos extratos vegetais de L. aurea foram reduzidos pela microbiota do solo para algumas espécies-alvo e potencializados para outras (Capítulo 1). Outra explicação possível para a resposta de A. polyphylla observada nos testes de crescimento em condições semi-naturais, é o fato de a espécie ocorrer tipicamente em áreas da fitofisionomia de mata seca, diferente das outras espécies nativas testadas neste estudo C. langsdorffii, L. chrysothrix e L. aurea, que ocorrem preferencialmente em áreas mais abertas do Cerrado, como no Cerrado "stricto sensu". A diferença geográfica nos locais de ocorrência de L. aurea e de A. polyphylla sugere que as espécies possivelmente não possuem uma relação coevolutiva forte, o que talvez tenha se refletido em uma maior suceptibilidade de A. polyphylla à ação alelopática de L. aurea em condições mais próximas às naturais. Por outro lado, o maior contato entre $L$. aurea e as espécies-alvo C. langsdorffii e L. chrysothrix, em decorrência da coexistencia no mesmo ambiente, pode ter promovido nestas espécies-alvo a existência de defesas mais eficazes contra aleloquímicos prejudiciais de $L$. aurea e talvez tenha possibilitado a relação de benefício observada entre as três espécies.

O comportamento de A. polyphylla, apesar de não se tratar de uma espécie exótica, mas de uma espécie nativa que não coexiste geograficamente com a espécie doadora, pode indicar que a experiência evolutiva das plantas, sendo elas exóticas ou não, é, de fato, um dos fatores importantes para a definição do padrão de distribuição 
de espécies existente no local de estudo. Esses resultados reforçam o entendimento de se considerar diversos fatores para o compreensão do papel da alelopatia nas comunidades vegetais. Para interpretações mais consistentes dos resultados de estudos que envolva o potencial alelopático de espécies exóticas e nativas, os trabalhos devem considerar tanto as características das espécies quanto o seu histórico evolutivo.

Idependentemente dos resultados encontrados neste trabalho não terem sido suficientes para a comprovação ou não da existência do padrão estabelecido pela hipótese de defesa de território no local de estudo, ainda assim, a descoberta de que $L$. aurea potencialmente possa inibir o crescimento inicial de $U$. decumbens, uma das gramíneas exóticas invasoras mais prejudiciais à conservação do Cerrado, pode ser considerada como mais uma ferramenta de apoio em projetos de restauração ecológica. A maior inibição do crescimento da parte radicular de $U$. decumbens observada na presença dos aleloquímicos de $L$. aurea, pode ser útil no controle desta gramínea exótica, já que raizes menos desenvolvidas em gramíneas podem facilitar sua remoção mecânica e possivelmente resultam na redução do potencial de sobrevivência e de rebrota destas plantas, especialmente nos meses de déficit hídrico típicos do Cerrado durante a estação seca. Todavia, este resultado deve ser visto como um dos instrumentos de apoio à prática da restauração ecológica em áreas invadidas pela $U$. decumbens, o qual deve estar aliado a outros instrumentos e técnicas para uma maior eficiência no restabelecimento vegetal, isso porque, apesar desta gramínea exótica aparenemente ter tido o crescimento inibido pelos compostos alelopáticos de L. aurea, ainda assim, mostrou maior crescimento do que a gramínea nativa testada - L. chrysothrix, demonstrando que mesmo após ser afetada negativamente pela ação alelopática da espécie doadora, ainda apresenta maior potencial competitivo do que a gramínea nativa. 
O fato dos crescimentos das espécies nativas C. langsdorffii e L. chrysothrix aparentemente terem sido aumentados na presença de aleloquímicos de L. aurea, reforça a utilidade da espécie em projetos de restauração ecológica, pois indica que $L$. aurea pode contribuir para que o restabelecimento vegetal aconteça de forma mais rápida. Esse resultado também pode servir de base para a seleção de um rol de espécies nativas com as mesmas características de C. langsdorffii e L. chrysothrix, as quais podem contribuir para o sucesso de projetos de restauração ecológica.

No geral, os aleloquímicos liberados por $L$. aurea não tiveram influência no desenvolvimento inicial das espécies-alvo em campo, pois não foram observadas diferenças entre os valores de germinação e crescimento inicial da maioria das espéciesalvo nas parcelas sem e com carvão ativado dentro das manchas de L. aurea. A única exceção foi a espécie $C$. langsdorffii que apresentou maior germinação nas parcelas sem carvão ativado dentro das manchas, se comparada às com carvão no mesmo local, o que indica que os aleloquímicos de L. aurea provavelmente estimularam a germinação desta espécie. Não foram observadas diferenças nos valores de germinação de C. langsdorffii nas parcelas sem e com carvão ativado fora das manchas de $L$. aurea, o que reforça a interpretação de que os aleloquímicos foram a provável causa do aumento da germinação da espécie. Sendo assim,os resultados de germinação em campo corroboram o padrão de resposta de $C$. langsdorffii constatado nas outras fases do trabalho, em condições de laboratório e em casa de vegetação.

Apesar de C. Langsdorffii ter tido a germinação aparentemente estimulada pelo contato com os aleloquímicos de L. aurea em campo, foi observado, na mesma condição, que o comprimento da parte aérea desta espécie-alvo, assim como o da outra espécie arbórea testada $-A$. polyphylla, foi menor do que o das duas gramíneas exóticas invasoras - A. gayanus e $U$. decumbens, padrão este, que em condições não 
experimentais, possivelmente pode dificultar o recrutamento das plântulas das espécies lenhosas, através da redução da luminosidade na superfície do solo. De fato, já é bem discutido na literatura que esta é uma das muitas características que tornam as gramíneas exóticas tão prejudiciais ao restabelecimento vegetal em áreas naturais (Holl 2002, Florentine \& Westbrooke 2004).

A maioria das espécies testadas apresentou germinação e crescimento inicial maior nas parcelas dentro das manchas de L. aurea. Esse padrão aliado ao fato dos aleloquímicos não terem afetado a maioria das espécies-alvo, sugere que condições ambientais foram as prováveis responsáveis pelo melhor desenvolvimento inicial das espécies-alvo em campo. O microclima mais ameno dentro das manchas, com menor temperatura e maior umidade podem ter sido decisivos para os resultados observados. De fato, Bezerra (2003) afirma que as variáveis temperatura, luminosidade e umidade são tão importantes para estabelecimento de plantas, principalmente nos estágios iniciais de desenvolvimento, que muitas vezes esses fatores são controlados, como no caso da produção de mudas.

Diante dos resultados obtidos nas três condições testadas: laboratório, casa de vegetação e campo, a hipótese do trabalho de que L. aurea possui potencial alelopático que produz maiores efeitos inibitórios no desenvolvimento das gramíneas exóticas invasoras A. gayanus e $U$. decumbens do que no de outras espécies nativas, especialmente as arbóreas A. polyphilla e C. langsdorffii, foi corroborado para duas espécies: $U$. decumbens e $C$. langsdorffii, já que a espécie exótica $U$. decumbens apresentou redução do seu crescimento inicial na presença de aleloquímicos de L. aurea em condições de laboratório e semi-naturais, e a espécie arbórea nativa C. langsdorffii apresentou melhor desenvolvimento inicial sob essa mesma influência: nas três condições testadas. Adicionalmente, os aleloquímicos foliares de L. aurea 
possivelmente também foram responsáveis pelo aumento do crescimento inicial de outra espécie nativa em condições semi-naturais: a gramínea L. chrysothrix. Todavia, esta hipótese não foi corroborada para as espécies A. gayanus e A. polyphylla, pois a gramínea exótica invasora A. gayanus só apresentou redução do crescimento inicial em condições laboratoriais, o que não foi observado nas outras condições: casa de vegetação e campo, portanto, o potencial alelopático de L. aurea sobre esta espécie não foi evidenciado. Já a espécie arbórea A. polyphylla apresentou o crescimento inicial reduzido na presença do extrato foliar de L. aurea em laboratório e também na presença dos aleloquímicos radiculares da espécie doadora em casa de vegetação, demonstrando, portanto, que L. aurea porduz efeitos inibitórios no crescimento desta espécie nativa.

Já é bem discutido que em estudos de alelopatia, especialmente nos realizados em campo, deve-se considerar vários cenários ambientais para que os efeitos alelopáticos sejam de fato evidenciados (Nilsson 1994, Del Fabbro 2014). Neste sentido, para a comprovação da alelopatia em campo, talvez a metodologia utilizada neste trabalho tenha sido muito simplificada, todavia, sua execução foi de extrema importância para a compreensão da complexidade de estudos de alelopatia em condições naturais, possibilitando o aperfeiçoamento do método utilizado. Para um melhor entendimento do papel da alelopatia nas interações planta-planta em campo, devem ser realizados trabalhos com a exclusão das condições ambientais que se sobrepuseram aos efeitos alelopáticos neste estudo, como por exemplo o plantio de espécies-alvo em parcelas com serrapilheira da espécie doadora em campo. Outra forma de facilitar as interpretações dos resultados de testes realizados campo é a separação da alelopatia de outros tipos de interferência, como por exemplo a competição por recursos (Nilsson 1994), o que pode ser feito com a realização de biensaios com a utilização de 
carvão ativado e de canos de PVC para separação de raízes das espécies receptora e doadora.

A despeito dos resultados obtidos em campo, as descobertas provenientes das outras fases do trabalho foram importantes para a confirmação de mais uma característica de $L$. aurea que reforça sua escolha como uma boa alternativa para uso em projetos de restauração ecológica: a potencial capacidade de inibição do desenvolvimento inicial da gramínea exótica $U$. decumbens e o estímulo ao melhor desenvolvimento de outras espécies nativas. Além disso, este trabalho pode servir de base para estudos futuros na área. 


\section{Discussão Geral}

O potencial alelopático de L. aurea foi identificado nas três condições testadas (laboratório, casa de vegetação e campo), em amplitudes diferentes e a partir de diversas evidências. Os resultados foram dependentes da espécie-alvo, do processo fisiológico avaliado (germinação ou crescimento inicial), do tipo de extrato ou da parte da planta doadora testada (folhas, serrapilheira ou raizes) e de fatores ambientais inerentes a cada condição.

Em laboratório, os efeitos dos compostos químicos presentes nas folhas e raizes de $L$. aurea tiveram uma intensidade maior do que nas outras condições. O extrato foliar da planta doadora foi responsável pela inibição de todas as espécies-alvo de alguma forma, tanto das espécies-modelo quanto das espécies exóticas e nativas testadas. Em contrapartida, em condições semi-naturais os efeitos dos aleloquímicos de L. aurea foram menos evidentes do que o observado em laboratório, já que um número menor de espécies-alvo foram afetadas pelos compostos alelopáticos das folhas secas e das raizes de $L$. aurea em casa de vegetação. No total, duas espécies nativas, uma gramínea ( $L$. chrysothrix) e uma arbórea (C. langsdorffii), apresentaram aumento do crescimento radicular em resposta aos aleloquímicos de $L$. aurea, e outras duas, uma exótica ( $U$. decumbens) e uma nativa arbórea (A. polyphylla), apresentaram redução do crescimento inicial, nas mesmas condições.

Em campo, as evidências de alelopatia em L. aurea foram ainda mais reduzidas, mais pôde ser observada no estímulo à germinação da espécie $C$. langsdorffii. As outras espécies-alvo aparentemente tiveram seus processos fisiológicos influenciados mais fortemente por fatores ambientais em condições naturais. 
A primeira hipótese do trabalho de que L. aurea possui potencial alelopático com efeitos inibitórios sobre o desenvolvimento das gramíneas exóticas invasoras, Andropogon gayanus e Urochloa decumbens, foi corroborada em parte e para uma das duas espécies, já que somente $U$. decumbens apresentou redução do crescimento inicial em decorrência do contato com aleloquímicos de L. aurea em mais de uma condição: laboratório e casa de vegetação, todavia essa resposta não foi observada em condições naturais. A outa espécie exótica invasora, A. gayanus, somente teve o crescimento inicial reduzido pelo extrato foliar de L. aurea em condições controladas, o que foi observado também em todas as outras espécies-alvo testadas neste bioensaio, tanto as exóticas quanto as nativas. Considerando que esse comportamento de A. gayanus não se repetiu no bioensaio com extrato de raiz de L. aurea em laboratório, nem nas outras condições: casa de vegetação e campo, não há evidências suficientes da suceptibilidade desta espécie à ação alelopática de L. aurea.

A segunda hipótese do trabalho de que o potencial alelopático de L.aurea apresenta menores efeitos inibitórios sobre as espécies nativas arbóreas C. langsdorffii e A. polyphylla e sobre a gramínea nativa L. chrysothris, também foi corroborado em parte e para algumas espécies. A espécie arbórea $C$. langsdorffii teve melhor desenvolvimento inicial na presença dos aleloquímicos de L. aurea, nas três condições testadas: laboratório, casa de vegetação e campo, e a gramínea nativa L. chrysothris aparentemente teve o crescimento inicial aumentado em decorrência do contato com os aleloquímicos foliareas de L. aurea em casa de vegetação, sem no entanto, mostrar o mesmo comportamento em laboratório e em campo. Por outro lado, esta hipótese foi refutada para a outra espécie nativa arbórea, A. polyphylla, já que a espécie apresentou redução do crescimento inicial em decorrência do contato com o extrato foliar de $L$. 
aurea em laboratório, e na presença dos aleloquímicos radiculares da planta doadora em casa de vegetação, o que evidencia que $L$. aurea potencialmente pode prejudicar o desenvolvimento inicial desta espécie nativa.

Os resultados encontrados neste trabalho confirmam a vantagem da utilização de L. aurea em projetos de restauração ecológica. O fato de L. aurea potencialmente inibir o crescimento de $U$. decumbens, e adicionalmente estimular o desenvolvimento de outras espécies nativas, pode trazer à prática da restauração uma série de possibilidades benéficas, que vão desde o aperfeiçoamento de técnicas, a redução de custos com o controle de $U$. decumbens, até a seleção de espécies nativas com melhor desempenho no crescimento e estabelecimento, que contribuirão de forma positiva ao restabelecimento da vegetação original do Cerrado.

Estudos baseados em padrões de distribuição de espécies em condições naturais, com hipóteses e justificativas claras, são fundamentais para o entendimento da complexidade das interações planta-planta em condições naturais e podem resultar em uma série de aplicações ecológicas e em contribuições para a conservação e o manejo de ambientes naturais. A realização de trabalhos abrangentes, nos quais sejam contempladas diversos fatores e condições (laboratoriais, semi-naturais e naturais) é importante para a redução de erros na interpretação de resultados, além de contribuir para o enriquecimento de metodologias em estudos de alelopatia, as quais se encontram em processo de construção e aperfeiçoamento no mundo inteiro. 


\section{Referências Bibliográficas}

Abhilasha, D.; Quintana, N.; Vivanco, J.; Joshi, J. 2008. Do allelopathic compounds in invasive Solidago canadensis s.l. restrain the native European flora? Journal of Ecology 96: 993-1001.

Adkins, S.; Ashmore, S. and Navie, S. 2007. Seeds: biology, development and ecology. Cambridge: CAB International, 496 p.

Aires, S. S.; Ferreira, A. G. \& Borghetti, F. 2005. Efeito alelopático de folhas e frutos de Solanum lycocarpum A. St-Hil. (Solanaceae) na germinação e crescimento de Sesanum indicum L. (Pedaliaceae) em solo sob três temperaturas. Acta Botânica Brasilica, 19(2): 339-344.

Allem, L. N.; Gomes, A. S.; Borghetti, F. 2014. Pequi leaves incorporated into the soil reduce the initial growth of cultivated, invasive and native species. Annals of the Brazilian Academy of Sciences. ISSN 0001-3765.

Almeida, F. S. 1991. Controle de plantas daninhas em plantio direto. Londrina: Circular 67. lapar, 34p.

Alves, S. M.; Arruda, M. S. P.; Souza Filho, A. P. S. 2002. Biossíntese e Distribuição de Substâncias Alelopáticas. In: Souza Filho, A. P. S.; Alves S. M., editores. Alelopatia: princípios básicos e aspectos gerais. Belém: Embrapa Amazônia oriental. p 79-109.

An, M.; Pratley, J. E.; Haig, T.; Jellett, P. 1997. Genotypic variation of plant species to the allelopathic effects of vulpia residues. Austral. J. Exp. Agric., v.37, p. 647-660.

Andrade, E. R. de et al. 2013. Efeito da microbiota do solo na atividade fitotóxica de extratos foliares de Stryphnodendron adstringens (Mart.) Coville. Iheringia. Série Botânica, v. 68, n. 2, p. 187-194.

Anese S. et al. 2015. Phitotoxic activity of different plant parts of Drimys brasiliensis miers on germination and seedling develepment. Biosc. J. v. 31, n. 3, p. 923-933.

Atale, N. et al. 2011. Phytochemical and Antioxidant Screening of Syzygisem cumini Seed Extracts: a comparative study. Journal of Pharmacy Research, v. 4, n. 12, p. 4530-4532.

Azevedo Neto, E. N. 2010. Potencial Alelopático de Leucena e de Sabiá na Germinação, na Emergência e no Crescimento Inicial do Sorgo. Monografia (Engenheiria Florestal), Universidade Federal de Campina Grande, Paraíba. 25 f. 
Barbosa, E. G.; Pivello, V. R. and Meirelles, S. T. 2008. Allelopathic Evidence in Brachiaria decumbens and its Potential to Invade the Brazilian Cerrado. Braz. arch. biol. technol. 51(4), 825-831.

Barney, J. N.; Sparks, J. P.; Greenberg, J.; Whitlow, T. H.; Guenther. A. 2009. Biogenic volatile organic compounds from an invasive species: impacts on plant-plant interactions. Plant Ecology 203:195-205.

Belinelo, V. J. et al. 2008. Alelopatia de Arctium minus Bernh (Asteraceae) na germinação e crescimento radicular de sorgo e pepino. Revista Caatinga 21.4.

Bensusan, N. 2006. Conservação da biodiversidade em áreas protegidas. Rio de Janeiro: FGV Editora.

Bezerra, F. C. 2003. Produção de mudas de hortaliças em ambiente protegido. Embrapa Agroindústria Tropical.

Blum, U. 1999. Designing laboratory plant debris-soil bioassays: some reflections. Principles and practices in plant ecology: allelochemical interactions. CRC, Boca Raton, p. 17-23.

Blum U. 2011. Plant-Plant Allelopathic Interaction. Phase II: Field/Laboratory Experiments. In: BLUM U. Plant-Plant.

Blum, U.; Gerig, T. M.; Worsham, A. D. and King, L. D. 1993. Modification of allelopathic effects of p-Coumaric acid on morning-glory seedling biomass by glucose, methionine, and nitrate. J. Chem. Ecol. 19: 2791-2811.

Bremer, K. 1994. Asteraceae: Cladistics and classification. Timber Press, Portland.

Burgos, N. R., et al. 2004. Growth inhibition and root ultrastructure of cucumber seedlings exposed to allelochemicals from rye (Secale cereale). Journal of chemical ecology 30.3: 671-689.

Callaway, R. M. and Aschehoug, E. T., 2000. Invasive plants versus their new and old neighbors: a mechanism for exotic invasion. Science 290: 521-523.

Callaway, R. M and Ridenour, W. M. 2004. Novel weapons: invasive success and the evolution of increased competitive ability. Front Ecol Environ 2:436-443.

Candido, A. C. S.; Schmidt, V.; Laura, V. A.; Faccenda, O.; Hess, S. C.; Simionatto, E. \& Peres, M. T. L. P. 2010. Potencial alelopático da parte aérea de Senna occidentalis (L.) Link ( Fabaceae, Caesalpinioideae ): bioensaios em laboratorio. Acta Botanica Brasilica 24(1): 235-242. 
Carvalho, S. J. C. 1993. Caracterização dos efeitos alelopáticos de Brachiaria brizantha cv. Marandu no estabelecimento das plantas de Stylosanthes guianensis var. vulgaris e cv. Bandeirante. Revista Sociedade Brasileira de Zootecnia. 22(6): 930- 937.

Chen, I. 1992. A conceptual framework for assessing allelochemicals in soil environment. In Allelpathy: Basic and applied Aspects (Rizvi, S. J.\& Rizvi, V., eds.). Londres: Capman \& Hall. p. 21-29.

Cheng, H. H. 1999. A conceptual framework for assessing allelochemicals in the soil environment. In: Narwall, S. S, editor. Allelopathy update. Enfield, N. H, USA: Science Pub. p 20-29.

Cheung, K. C. et al. 2009. Relação entre a presença de vegetação herbácea e a regeneração natural de espécies lenhosas em pastagens abandonadas na Floresta Ombrófila Densa do Sul do Brasil. Acta bot. bras. 23(4): 1048-1056.

Chon, S. U \& Nelson, C. J. 2010. Allelopathy in Compositae plants: a review. Agron Sust Dev 30:349-358.

Chou, C. H. 1999. Role of allelopathy in plant biodiversity and sustainable agriculture. Critical Review in Plant Sciences 18: 609-636.

Chou, C. H. 2006. Introduction to allelopathy. Cap. 1, p. 1-10. in Reigosa, M. J.; Pedrol, N.; Gonzalez, L. (editors). Allelopathy: a physiological process with ecological implications. Netherlands: Springer.

Chung, I. M.; Ahn, J. K.; Yun, S. J. 2001. Assesment of allelopathic potential of barnyard grass (Echinochloa crus-galli) on rice (Oriza sativa L.) cultivars. Crop Protection, Guildford, v. 20, n. 10, p. 921-928.

Costa, S. M. L. and Pasin, L. A. A. P. 2015. "Potencialidade Alelopática de Extratos de Ingá sobre o Desenvolvimento Inicial de Plântulas de Ipê Amarelo do Cerrado." Revista Científica da FEPI 6.1.

Coutinho, L. M. 1982. Aspectos ecológicos da saúva no cerrado - os murundus de terra, as características psamofíticas das espécies de sua vegetação e a sua invasão pelo capim-gordura. Revista Brasil Bot. 42, p. 147-153.

Cummings, J. A.; Parker, I. M.; Gilbert, G. S., 2012, Allelopathy: a tool for weed management in forest restoration, Plant Ecol. 213:1975-1989.

D'antonio, C. M and Vitousek, P. M. 1992. Biological Invasions by Exotic Grasses, the Grass/Fire Cycle, and Global Change. Annual Review of Ecology and Systematics, Vol. 23, p. 63-87. 
Da Silva, L. F. 2008. Atributos Físicos e Suscetibilidade à Compactação de Solos sob Pastagens Cultivadas no Norte de Minas Gerais. Diss. Universidade Estadual de Montes Claros.

Del Fabbro, C.; Güsewell, S; Prati, D. 2014. Allelophathic effects of three plant invaders on germination of native species: a field study. Biol Invasions 12: 10351042.

Dematteis, M. \& Almeida, G. 2015. Lista de Espécies ds Flora do Brail. (Jardim Botânico do Rio de Janeiro) Acesso em 21 de Junho de 2015, disponível em:http://floradobrasil.jbrj.gov.br/jabot/floradobrasil/FB27132.

Dorning, M. and Cipollini, D. 2006. Leaf and root extracts of the invasive shrub, Lonicera maakii, inhibit seed germination. Plant Ecology, v. 184, p. 287-296.

Drenovsky, R. E.; Grewell, B. J.; D'antonio, C. M. et al. 2012. A functional trait perspective on plant invasion. Annals of Botany, v.110, p.141-153.

Durigan, G. 2008. Bases e Diretrizes para a Restauração da Vegetação do Cerrado (Cap. 3) in Kageyama, P. Y.; Oliveira, R. E.; Moraes, L. F. D.; Engel, V. L., Gandara, F. B. (organizadores). Restauração Ecológica de Ecossistemas Naturais. 1 ed. Botucatu, SP: FEPAF.

Farias, R.; Alves, E. R.; Martins, R. C.; Barboza, M. A.; Zanenga-Godoy, R.; Reis, J. B. \& Rodrigues-da-Silva, R. 2002. Caminhando pelo cerrado: plantas herbáceo arbustivas, caracteres vegetativos e organolépticos. Brasília, EDUnB.

Fenner, M. 2000. Seeds: the ecology of regeneration in plant comunities. New York: Cambrige university Press.

Ferreira, A. G. et al. 2001. Germinação de sementes de Asteraceae nativas no Rio Grande do Sul, Brasil. Acta Botanica Brasilica 15.2: 231-242.

Ferreira, A. G. 2004. Interferência, competição e alelopatia. In Germinação: do básico ao aplicado (Ferreira, A.G \& Borghetti, F., eds). Artmed, p.251-262.

Ferreira, A. G. \& Áquila, M. E. A. 2000. Alelopatia: uma área emergente da ecofisiologia. Revista Brasileira de Fisiologia Vegetal 12(edição especial): 175204.

Ferreira, A. G.; Borghetti, F. 2004. Germinação: do básico ao aplicado. Porto Alegre: Artmed.

Florentine, S. K. \& Westbrooke, M. E. 2004. Restoration on abandoned tropical pasturelands - do we know enough? Journal for Nature Conservation 12:85-94. 
França, A. C.; Souza, I. F. de; Santos, C. C.; Oliveira, E. Q. de; Martinoto, C. 2008. Atividades Alelopáticas de Nim Sobre o Crescimento de Sorgo, Alface e Picão-preto. Ciênc. Agrotec., Lavras, v.32, n. 5, p.1374-1379, set/out 2008.

Freitas, G. K. 1999. Invasão biológica pelo capim-gordura (Melinis minutiflora Beauv.) em um fragmento de Cerrado (A.R.I.E Cerrado Pé-de-Gigante, Santa Rita do Passa Quatro, SP). Departamento de Ecologia Geral, Instituto de Biociências, Universidade de São Paulo, São Paulo. Dissertação de Mestrado.

Gatti, A. B.; Ferreira, A. G.; Arduin, M.; Perez, S. C. G. de A. 2010. Allelopathic effects of aqueous extracts of Artistolochia esperanzae O. Kuntze on developement of Sesamun indicum L. seedlings. Acta bot. bras, v. 24, n. 2, p. 454-466.

Hadacek, F. 2002. Secondary metabolites as plants traits: Current assessment and future perspectives. Critical Reviews in Plant Sciences 21(4): 273-322.

Haemig, P.D. 2011. Engenheiros do Ecossistema: Organismos que Criam, Modificam e Mantêm Habitats. ECOLOGIA. INFO 12 http: www.ecologia.info/engenheiros-doecossistema.htm Acesso em 05/12/2015.

Hils, M. H.; Vankat, J. L. 1982. Species removals from a first-year old-field plant community. Ecology 63:705-711

Holl, K. D. 2002. Effect of shrubs on tree seedling establishment in an abandoned tropical pasture. Journal of Ecology 90: 179-187.

Hooper, E.; Condit, R.; Legendre. P. 2002. Responses of 20 native tree species to reforestation strategies for abandoned farmland in Panama. Ecol Appl 12:16261641.

Horowitz , C.; Oliveira, A. S.; Da Silva, V.; Pacheco, G. \& Sobrinho, R. I. 2013 Manejo da Flora Exótica Invasora no Parque Nacional de Brasília: Contexto Histórico e Atual. Biodiversidade Brasileira, 3(2): 217-236.

Inderjit. 2001. Soil: Enviromental effects on allelochemical activity. Agronomy Journal 93: 79-84.

Inderjit. 2005. Soil microorganisms: An important determinant of allelopathic activity Plant and Soil 274: 227-236.

Inderjit and Callaway; R. M. 2003. Experimental designs for the study of allelopathy. Plant and Soil 256: 1-11.

Inderjit and Dakshin, K. M. M. 1995. On laboratory biossays in Allelopathy. The Botanical Review, v. 61, n. 1. 
Inderjit and Dakshini, K. M. M. 1999. Bioassays for Allelopathy: Interactions of soil organic and inorganic constituents. In: Inderjit; Dakishini, K. M. M.; Foy, C. L., editors. Principles and practices in plant ecology: allelochemical interactions. Boca Raton: CRS Press. p 35-44.

Inderjit and Nilsen, E. T. 2003. Bioassays and field studies for allelopathy in terrestrial plants: progress and problems. Crit. Rev. Pl. Sci. 22, 221-238.

Inderjit and Weston, L. A. 2000. Are laboratory biossays for allelopathy suitable for prediction on field responses? Journal of Chemical Ecology, v. 26, n. 9.

Jarchow, M. E. and Cook, B. J. 2009. Allelopathy as a mechanism for the invasion of Typha angustifolia. Plant Ecology 204:113-124.

Johnson, E. A. 1977. Succesion an unfinished revolution. Ecology, v. 60, n. 238-240.

Jones, E .R.; Wishnie, M .H.; Deago J.; Sautu A.; Cerezo A. 2004. Facilitating natural regeneration in Saccharum spontaneum (L.) grasslands within the Panama Canal watershed: effects of tree species and tree structure on vegetation recruitment patterns. For Ecol Manag 191:171-183.

Joo Kim, T.; Montagnini, F.; Dent, D. 2008. Rehabilitating abandoned pastures in Panama: control of the invasive exotic grass, Saccharum spontaneum L., using artificial shade treatments. J Sustain For 26:192-203.

Judd, W. S.; Campbel, C. S.; Kellongg, E. A.; Steens, P. F.; Donogue, M. J. 2009. Sistemática vegetal: um enfoque filogenético. 3.ed. Porto Alegre: Artmed, 612p.

Kabouw, P.; Nab, M.; Van Dam, N.M. 2010. Activated carbon addition affects substrate $\mathrm{pH}$ and germination of six plant species. Soil Biology and Biochemistry 42:11651167.

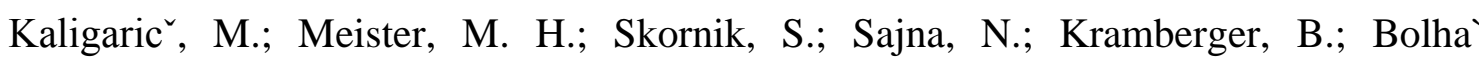
Nordenkampf, H. R. 2011. Grassland succession is mediated by umbel liferous colonizers showing allelopathic potential. Plant Biosyst 145:688-698

Kaur, H.; Kaur, R.; Kaur, S.; Baldwin, I. T. \& Inderjit. 2009. Taking Ecological Function Seriously: Soil Microbial Communities Can Obviate Allelopathic Effects of Released Metabolites. PLoS ONE 4(3): e 4700.

King, R. M. \& Dawson, H. W. 1975. Cassini on Compositae 1-3. Oriole, New York.

Koitabashi, R. et al. 1997. 1, 8 - Cineole inhibits root growth and DNA synthesis in the root apical meristem of Brassica campestris L. Journal of Plant Research 110.1 (1997): 1-6. 
Kolar, C. S. \& Lodge, D. M. 2001. Progress in invasion biology: predicting invaders. TREE, 16, 199-205.

Kulmatiski, A. 2011. Changing soils to manage plant communities: activated carbon as a restoration tool in ex-arable fields. Restoration Ecology 19:102-110.

Kulmatiski, A.; Beard, K. H.; 2006. Activated carbon as a restoration tool: potential for control of invasive plants in abandoned agricultural fields. Restoration Ecology $14: 251-257$.

Lankau, R. 2010. Soil microbial communities alter allelopathic competition between Alliaria petiolata and a native species. Biological Invasions 12.7: 2059-2068.

Lau, J. A.; Puliafico, K. P.; Kopshever, J. A.; Steltzer, H.; Jarvis, E. P.; Schwarzlander, M.; Strauss, S.Y.; Hufbauer, R.A. 2008. Inference of allelopathy is complicated by effects of activated carbon on plant growth. New Phytologist 178:412-423.

Lima-Ribeiro, M. \& Prado, E. 2007. Distribuição Espacial de uma População de Vernonia aurea Mart. ex DC. (Asteraceae) em um Fragmento de Cerradão no Município de Paiapônia, GO, Brasil. Bioscience Journal , 23 (3), pp. 81-89.

Lockwood et al. 2007. Invasion Ecology/Julie L. Lockwood, Martha F. Hoopes, Michael P. Marchetti. Blackwell Publishing. 304p.

Lorenzi, H., 2000. Plantas daninhas do Brasil: terrestres, aquáticas, parasitas e tóxicas. Nova Odessa, Instituto Plantarum.

Lovett, J.; Ryuntyu, M. 1992. Allelopathy: Broadening the context. In: Rizvi, S. J. H., Rizvi, V., editors. Allelopathy: Basics and applied aspects. London: Chapman Hall. p 480.

Macedo, M. C. M. 2002. Degradação, renovação e recuperação de pastagens cultivadas: ênfase sobre a região dos cerrados. In: Obeid, J. A.; Pereira, O. G.; Fonseca, D. M.; Nascimento Jr, D. (Eds). Simpósio sobre manejo estratégico da pastagem, 1, Viçosa, 2002. Anais... Viçosa: UFV. p. 37-146.

Macías, F. A.; Molinillo, J. M. G.; Varela, R. M.; Galindo, J. G. C. 2007. Allelophaty a natural alternative for weed control. Pest Management Science. 63: 327-348.

Maraschin-Silva, F. and Aquila M. E. A.. Potencial alelopático de espécies nativas na germinação e crescimento inicial de Lactuca sativa L.(Asteraceae). Acta Botanica Brasilica 20.1 (2006): 61-69.

Martins, C. R.; Hay, J. D. V.; Walter, B. M. T.; Proença, C. E. B. \& Vivaldi, L. J. 2011. Impacto da invasão e do manejo do capim-gordura (Melinis minutiflora P. Beauv.) 
sobre a riqueza e biomassa da flora nativa do Cerrado sentido restrito. Revista Brasileira de Botânica, 34(1): 73-90.

Meiners, S. J. et al. 2012. Functional correlates of allelopathic potential in a successional plant community. Plant Ecology 215: 661-672.

Miranda, J. C. Sucessão Ecológica: Conceitos, Modelos e Perspectivas. SaBios: Rev. Saúde e Biol. Vol. 4, n. 1, p. 31-37.

MMA - Ministério do Meio Ambiente. 2010. Plano de ação para prevenção e controle do desmatamento e das queimadas no Cerrado - PPCerrado.

Morin, P. J. 1999. Community Ecology. Blackwell Science, Inc. 424p.

Moosavi, A.; Tavakkol Afshari, R.; Asadi, A.; Gharineh, M. H. 2011. Allelopathic effects of aqueous extract of leaf, steam and root of Sorghum bicolor of seed germination and seedling growth of Vigna radiata L. Notulae Scientia Biologicae, v. 3, n. 2, 114-118.

Muller, C. H. 1969. Allelopathy as a factor in ecological processes. Vegetatio 18: 348357.

Muraschin, F \& Aquila, M. E. F. 2006. Potencial alelopático de espécies nativas na germinação e crescimento inicial de Lactuca sativa L. (Asteraceae). Acta bot. bras. 20(1): 61-69.

Murrell, C. et al. 2011. Invasive knotweed affects native plants through allelopathy. American Journal of Botany 98(1): 38-43.

Myster, R.W. \& Pickett, S. T. A. 1992. Dynamics of associations between plants in ten old fields during 31 years of succession. J Ecol 80:291-302

Nentwig, W. (Ed). 2007. Biological Invasions. Springer. New York.

Nilsson, M. C. 1994. Separation of allelopathy and resource competition by the boreal dwarf shrub Empetrum hermaphroditum Hagerup. Oecologia 98: 1-7.

Nolan, N. E. et al. 2014. Activated carbon decreases invasive plant growth by mediating plant-microbe interactions. AOB Plants. Special Issue: The role below-ground processes in mediating plant invasions.

Novaes, P.; Molinillo, J. M. G.; Varela, R. M., Macías, F. A. 2013. Ecological phytochemistry of Cerrado (Brazilian savanna) plants. Phytochem Rev 12:839-85.

Oliveira, M. C., Pereira, D. J. S., Ribeiro, J. F. 2012. Manual de viveiro e produção de mudas: espécies arbóreas nativas do cerrado, Brasília, DF:EMBRAPA, 64p. 
Oliveira, M. G. F. de, et al. 2014. Potencial alelopático de extratos aquosos de folhas de Mimosa tenuiflora e semente de Achyrocline satureioides sobre a germinação e desenvolvimento de plântulas de alface. Agropecuária Científica no Semiárido 10.3 (2014): 26-33.

Pennacchio, M.; Jefferson, L. V. \& Havens, K. 2005. Arapdopsis thaliana: a new test species for phytotoxic bioassays. Journal of Chemical Ecology, 31(8): 1877- 1885.

Pearson, H. L. and Vitousek, P. M. 2001. Stand dynamics, nitrogen accumulation, and symbiotic nitrogen fixation in regenerating stands of Acacia koa. Ecol Appl 11:1381-1394.

Pereira, B. Fraga, Sbrissia, A. F and Serrat, B. M. 2008. Alelopatia intra-específica de extratos aquosos de folhas e raízes de alfafa na germinação e no crescimento inicial de plântulas de dois materiais de alfafa: crioulo e melhorado. Ciencia rural 38.2: 561-564.

Pires, N. de M. \& Oliveira, V. R. 2011. Alelopatia. Embrapa Hortaliças - Capítulo em livro técnico-científico.

Prati, D. and Bossdorf, O. 2004. Allelopathic inhibition of germination by Alliaria petiolata (Brassicaceae). American Journal of Botany 91: 285-288. doi: 10.3732/ajb.91.2.285.

Pivello, V. R. 2011. Invasões Biológicas no Cerrado Brasileiro: Efeitos da Introdução de Espécies Exóticas sobre a Biodiversidade. ECOLOGIA. INFO 33. Disponível em: http://www.ecologia.info/cerrado.htm. Acesso em 23 de dezembro de 2015.

R. Development Core Team. 2015. R: A language and environment for statistical computing. R. Foundation for Statistical Computing, R version 3.2.1 (2015-0618). São Paulo, Brazil. URL http://www.vps.fmvz.usp.br/CRAN/.

Reigosa, M. et al. 2013. Allelopathic research in Brazil. Acta Botanica Brasilica 27.4: 629-646.

Rice, E. L. 1984. Allelopathy. Academic Press. New York. 422 p. Santana, D. G.; Ranal, M. A.; Mustafa, P. C. Y. \& Silva, R. M. G. 2006. Germination measurements to evaluate allelopathic interactions. Allelopathy Journal, 17(1): 43-52.

Richardson, D. M.; Pyšek, P.; Rejmánek, M.; Barbour, M. G.; Panetta, F. D.; West, C. J. 2000. Naturalization and invasion of alien plants: concepts and definition. Diversity and Distribution, v. 6, n. 93-107. 
Robinson, H. 1987a. Studies in the Lepidaploa Complex (Vernonieae: Asteraceae) IIThe new genus Echinocoryne. Proceedings of the Biological Society of Washington 100:584-589.

Robinson, H. 1988a. Studies in the Lepidaploa Complex (Vernonieae: Asteraceae) V The new genus Chrysolaena. Proceedings of the Biological Society of Washington 101:952-958.

Robinson, H. 1988b. Studies in the Lepidaploa Complex (Vernonieae: Asteraceae) VI A genus, Aynia. Proceedings of the Biological Society of Washington 101:959965.

Robinson, H. 1990. Studies in the Lepidaploa Complex (Vernonieae: Asteraceae) VII The new genus, Lepidaploa. Proceedings of the Biological Society of Washington 103:464-498.

Robinson, H. 1996. The Paralychnophora group of Eremanthus (Vernonieae: Asteraceae). Rhodora 98:85-93.

Robinson, H. 1999. Generic and subtribal classification of American Vernonieae. Washington, Smithsonian Contributions to Botany 89:1-116.

Romeo J. T. and Weidenhamer J. D. 1998. Bioassays for allelopathy in terrestrial plants In Methods in Chemical Ecology. Vol. 2. Bioassay Methods. Eds. K F Hayne and J G Millar. pp. 179-211. Kluwer Academic Publishers, Norvell, MA.

Sampaio, A. B. et al. 2015. Guia de Restauração do Cerrado, Volume 1: semeadura direta. Brasília: Universidade de Brasília, Rede de Sementes do Cerrado. 40p.

Sampaio, A. B. and Schmidt, I. B. Espécies Exóticas Invasoras em Unidades de Conservação Federais do Brasil. Biodiversidade Brasileira, v. 3, n. 2, p. 32-49, 2013 .

Santos, S.; Moraes, M. L. L.; Rezende, M. O. O.; Souza Filho, A. P. S. 2011. Potencial alelopático e identificação de compostos secundários em extratos de calopogônio (Calopogonium mucunoides) utilizando eletroforese capitar. Eclética Química, v. 36, n. 2, 2011. (São Paulo).

Schertzer, J.W.; Boulette, M. L.; Whiteley, M. 2009. More than a signal: non-signaling properties of quorum sensing molecules. Trends in Microbiology 17:189-195.

Snedecor, G. W. \& Cochran, W. G. 1978. Métodos estatísticos. 5.ed. México: Compañia Editorial Continental, 593p. 
Society for Ecological Restoration International - SER. The Science and Practice of Ecological Restoration. Donald A. Falk, Margaret A. Palmer, and Joy B. Zedler (ed). Island Press 2006. 377p.

Souza Filho, A. P. da S.; Alves, S. de M. 2002. Alelopatia: princípios básicos e aspectos gerais. Belém: Embrapa Amazônia Oriental.

Souza Filho, A. P. S.; Alves, S. M. 2002b. Mecanismos de ação dos agentes alelopáticos. In: Souza Filho, A. P. S.; Alves, S. M., editores. Alelopatia: princípios básicos e aspectos gerais. Belém: Embrapa Amazônia Oriental. p 131-154.

Souza Filho, A. P. S. et al. 2010. Metodologias empregadas em estudos de avaliação da atividade alelopática em condições de laboratório - revisão crítica. Planta Daninha, Viçosa-MG, v. 28 (3), p. 689-697.

Srikanth, J., Pushpalatha, N. A. 1991. Status of biological-control of Parthenium hysterophorus in India - A review. Insect Science and its Application, Kenya, V. 12, n. 4 , p. 347-359.

Szczepanski, A. J. 1977. Allelopathy as a means of biological control of water weeds. Aquatic Biol. 3: 193-197.

Tang, C. S. W. F. et al. 1995. Plant stress and allelopathy. In: Allelopathy: Organisms, Processes, and Applications. pp. 142-157.

Turk, M. A. and Tawaha, A. M. 2003. Allelopathic effect of black mustard (Brassica nigra L.) on germination and growth of wild oat (Avena fatua L.). Crop Protection, v. 22, p. 673-677, 2003.

Wagner, H. and Bladt, S. 2001. Plant Drug Analysis: a thin layer chromatograph atlas. 2 ed. Alemanha: Springer.

Wandscheer, A. C. D. and Pastorini, L. H. 2008. "Allelopathic interference of Raphanus raphanistrum L. on the germination of Lactuca sativa L. and Solanum lycopersicon L." Ciência Rural 38.4: 949-953.

Wardle, D. A.; Nilsson, M-C.; Gallet, C.; Zackrisson, O. 1998. An ecosystem-level perspective of allelopathy. Biol $\operatorname{Rev}$ 73:305-319.

Weidenhamer, J D. 1996. Distinguishing resource competition and chemical interference: overcoming the methodological impasse. Agron. J. 88, 866-875.

Westoby M, Wright IJ (2006) Land-plant ecology on the basis of functional traits. Trends Ecol Evol 21:261-268. 
Whittaker, R. H. 1970. The biochemical ecology of higher plants. Chemical ecology 3: 43-70.

White, R. H., Worsham, A. D. and Blum, U. 1989. Allelopathic potential of legume debris and aqueous extracts. Weed Science (1989): 674-679.

Williams, D. G. and Baruch, Z. 2000. African grass invasion in the Americas: ecosystem consequences and the role of ecophysiology. Biological Invasions 2, p. 123-140.

Wishnie, M. H.; Dent, D. H.; Mariscal, E.; Deago, J.; Cedeno, N.; Ibarra, D.; Condit, R.; Ashton, P. M. S. 2007. Initial performance and reforestation potential of 24 tropical tree species planted across a precipitation gradient in the Republic of Panama. For Ecol Manag 243:39-49.

Wu, H.; Prtley, J.; Leerle, D.; Haig, T.; An, M. 2001. Screening Methods for the Evaluation of Crop Allelopathic Potencial. The Botanical Review, v. 67, n. 3.

Wurst, S. and Van Beersum, S. 2009. The impact of soil organism composition and activated carbon on grass-legume competition. Plant and Soil 314:1-9.

Zappi, D. C. et al. 2015. Growing knowledge: an overview of Seed Plant diversity in Brazil. Rodriguésia, Rio de Janeiro , v. 66, n. 4, p. 1085-1113.

Zenni, R. D. 2014. Analysis of introduction history of invasive plants in Brazil reveals patterns of association between biogeographical origin and reason for introduction. Austral Ecology 39:401-407.

Zenni, R. D. 2015. The naturalized flora of Brazil: a step towards identifying future invasive non-native species. Rodriguésia 66:1137-1144. 